\title{
BRACHYURAN DECAPODS (INCLUDING FIVE NEW SPECIES AND ONE NEW GENUS) FROM JURASSIC (OXFORDIAN-KIMMERIDGIAN) CORAL REEF LIMESTONES FROM DOBROGEA, ROMÂNIA
}

\author{
A thesis submitted \\ to Kent State University in partial \\ fulfillment of the requirements for the \\ degree of Masters of Science
}

by

OVIDIU D. FRANŢESCU

May, 2009 
Thesis written by

\section{OVIDIU D. FRANŢESCU}

B.S., Faculty of Geology and Geophysics, University of Bucharest, România, 2007

M.S., Kent State University, 2009

Approved by

, Rodney Feldmann, Advisor

, Daniel Holm, Chair, Department of Geology

, Timothy Moerland, Dean, College of Arts and Sciences 


\section{TABLE OF CONTENTS}

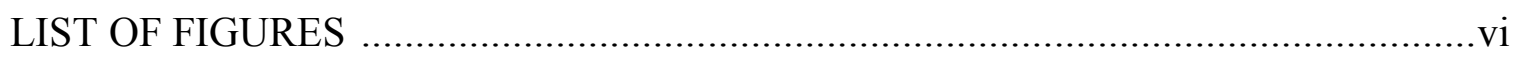

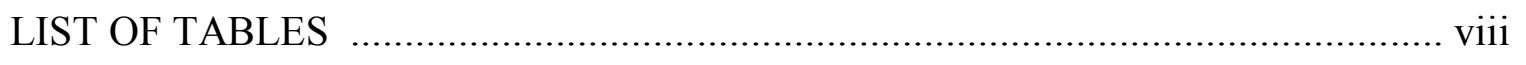

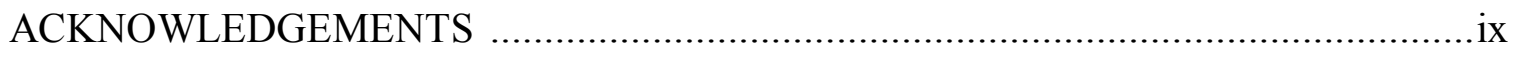

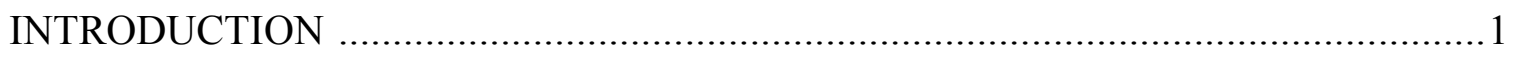

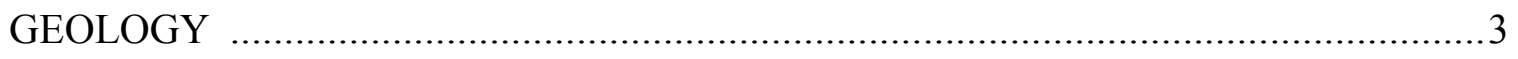

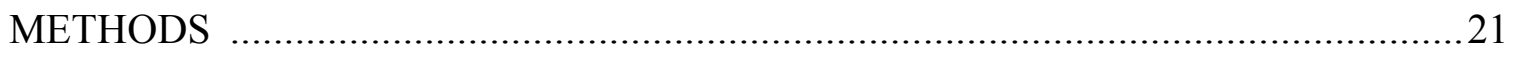

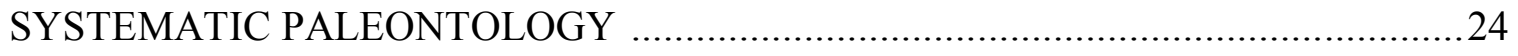

Superfamily Homolodromioidea ALCOCK 1899 .................................... 24

Family Goniodromitidae BEURLEN 1932 .......................................24

Goniodromites REUSS 1858 ............................................24

Goniodromites polyodon REUSS 1858 ........................25

Goniodromites cf. G. bidentatus REUSS 1858 .................30

Goniodromites n. sp. FRANȚESCU 2009.........................34

Goniodromites sp. ............................................... 38

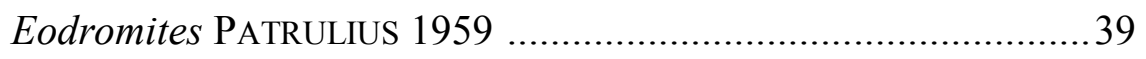

Eodromites grandis VON MEYER 1857..........................39

Family Tanidromitidae SCHWEITZER \& FELDMANN 2008 [imprint 2007] 44 
Tanidromites SCHWEITZER \& FELDMANN 2008 [imprint 2007].... 44

Tanidromites cf T. richardsoni WOODWARD 1907 45

Tanidromitidae ng. n. sp. FrANȚESCU 2009 49

Tanidromitidae n. g. n. sp. FRANŢESCU 2009

Family Prosopidae VON MEYER 1860 ............................................53

Laeviprosopon GLAESNER 1933 ........................................53

Laeviprosopon n. sp. FRANŢESCU 2009 ..........................53

Superfamily Glaessneropsoidea PATRULIUS 1959 ....................................58

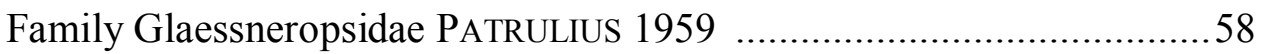

Verrucarcinus SCHWEITZER \& FELDMANN 2009 ......................58

Verrucarcinus n. sp. FRANȚESCU 2009 .........................59

Family Lecythocaridae SCHWEITZER \& FELDMANN 2009 ......................6 64

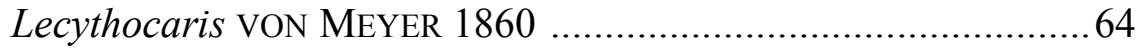

Lecythocaris n. sp. FRANŢESCU 2009 ............................64

Family Longodromitidae SCHWEITZER \& FELDMANN 2009 ...................69

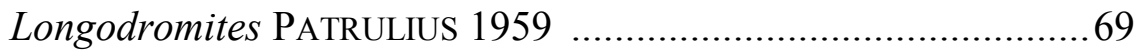

Longodromites angustus REUSS 1858 ........................69

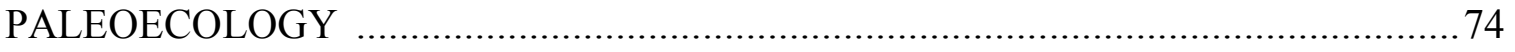

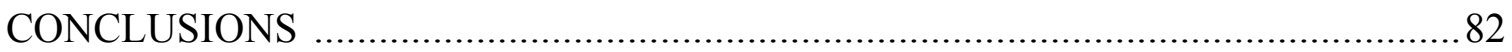

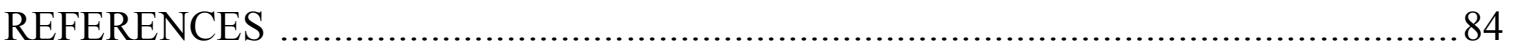

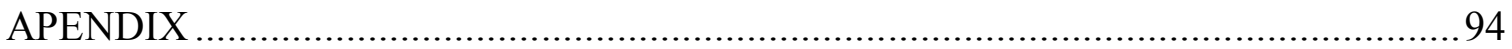




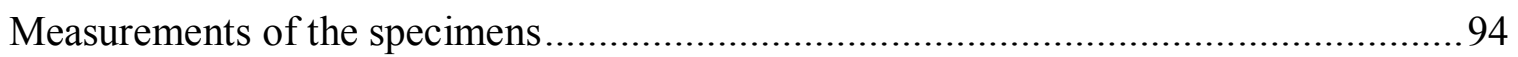

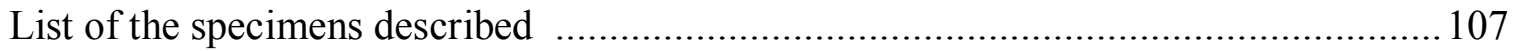




\section{LIST OF FIGURES}

Fig. 1. - Main tectonic units from Dobrogea ............................................................4

Fig. 2. - Geological section through Central Dobrogea ............................................ 6

Fig. 3. - Stratigraphic chart for Central Dobrogea.................................................... 8

Fig. 4. - Geologic section through the central part of Casimcea Syncline ....................... 9

Fig. 5. - Simplified stratigraphic column from the Piatra quarry ................................11

Fig. 6. - Facies distribution on the carbonate ramp of Central Dobrogea ......................... 12

Fig. 7. - Geological section along the left bank of Cechirgea Valley and Veriga Channel

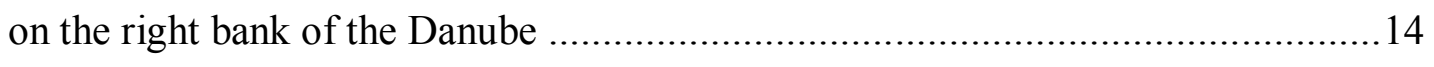

Fig. 8. - Simplified stratigraphic column and facies types for Tichileşti - Topalu area.......15

Fig. 9. - Outcrop images from Topalu and Cheia ................................................. 17

Fig. 10. - Branching coral colony at Topalu..................................................... 18

Fig. 11. - Diagram showing standard terminology used to describe decapod carapaces......22 
Fig. 12. - Principal axis used for measurements .................................................23

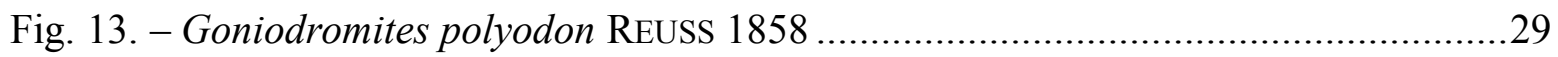

Fig. 14. - Left antero-lateral fragment of Goniodromites cf. G. bidentatus REUSS 1858 .....33

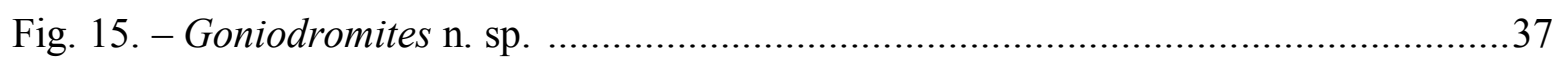

Fig. 16. Eodromites grandis VON MEYER 1857 ..........................................................43

Fig. 17. - Tanidromites cf. T. richardsoni WOODWARD 1907......................................48

Fig. 18. - Tanidromitidae n. g. n. sp............................................................ 52

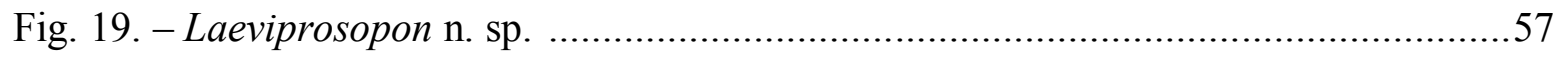

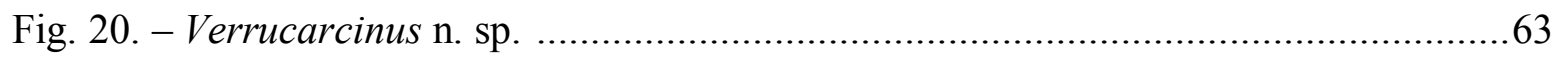

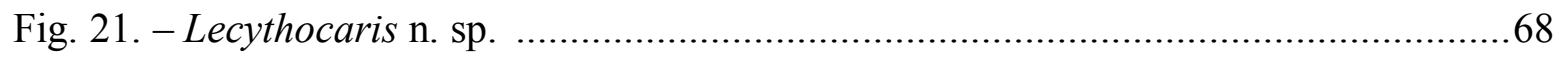

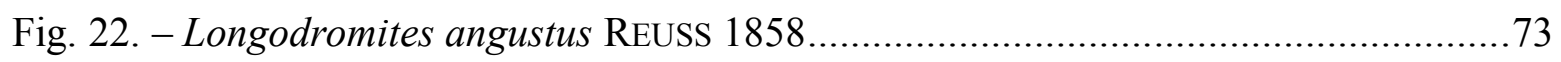

Fig. 23. - Paleogeographic reconstruction at $156 \mathrm{Ma}$.............................................. 75

Fig. 24. - Associated fauna from coral reefs ..................................................... 76

Fig. 25. - Abundance of decapods in coral reef environment from central Dobrogea .........77

Fig. 26. - Abundance differences between coral and sponge reefs from central Dobrogea .79

Fig. 27. - Decapod abundance by environment and locality from România......................80

Fig. 28. - Modified version of the triple factor model for Jurassic reefs ......................... 81 


\section{LIST OF TABLES}

Table 1. - Measurements in mm for Goniodromites polyodon REUSS 1858 ......................94

Table 2. - Measurements in mm for Goniodromites cf. G. bidentatus REUSS 1858 ...........96

Table 3. - Measurements in mm for Goniodromites n. sp. FrANȚESCU 2009....................97

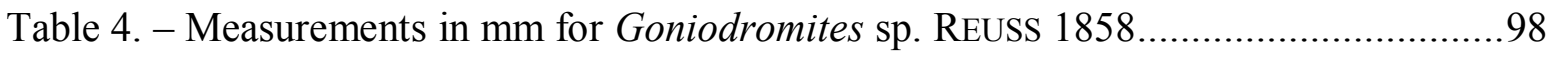

Table 5. - Measurements in mm for Eodromites grandis VON MEYER 1857..................... 100

Table 6. - Measurements in mm for Tanidromites cf. T. richardsoni WoODWARD 1907 ....101

Table 7. - Measurements in mm for Tanidromitidae n. g. n. sp. FRANŢESCU 2009 ..............102

Table 8. - Measurements in mm for Laeviprosopon n. sp. FRANŢESCU 2009.................... 103

Table 9. - Measurements in mm for Verrucarcinus n. sp. FRANŢESCU 2009...................... 104

Table 10. - Measurements in mm for Lecythocaris n. sp. FRANȚESCU 2009 ...................... 105

Table 11. - Measurements in mm for Longodromites angustus REUSS 1858 .................... 106 


\section{ACKNOWLEDGEMENTS}

I would like to thank a series of people that helped me throughout this research: IULIANA LAZĂR, from University of Bucharest for her help collecting specimens and deciphering the local geology of central Dobrogea; MARIUS STOICA, from University of Bucharest, for his help during field work and collecting specimens; and also many thanks to ADINA COSTACHE and AUBREY SHIRK who helped me to collect specimens.

Many thanks to CRISTINA ROBINS who assisted me in specimen description and gave in valuable assistance in compiling, editing and formatting of this paper.

Special thanks to my advisors RODNEY FELDMANN and CARRIE SCHWEITZER for their huge help and for their assistance in this project, from sample collecting under the hot Dobrogean sun, to preparation and description of the specimens, and to properly identifying and classifying the specimens.

This research was possible with partial funding from NSF INT-03136006 and EF0531670 to FELDMANN and SCHWEITZER and CNCSIS Grants 304/2003-2005 and 1022/2006-2007 to IULIANA LAZĂR. 


\section{INTRODUCTION}

Analysis of the fossil decapod faunas in coral reefs from localities at Topalu and Piatra in Central Dobrogea, România, yielded five new species and one new genus belonging to superfamilies Homolodromioidea ALCOCK 1899, and Glaessneropsoidea PATRULIUS 1959. Comparison of the abundance and diversity of decapod faunas from these Jurassic coral reefs with the abundance and diversity of decapod faunas from sponge-algal reefs in the same geographic area and of the same age (middle Oxfordian) has led to some interesting paleoecological differences. The coral reef environments yielded 30 specimens of decapods that represented six families in seven genera and ten species, including the new taxa. The sponge reef environments yielded 22 specimens that represented only three families with four genera and five species. These two different types of environments share only one genus in common, and no species.

Thus, the number of specimens is similar, but the diversity is markedly different. Furthermore, the nearly complete taxonomic difference between the environments (no shared species and only one shared genus) suggests that the environments selected for different adaptations, leading to niche partitioning within and between habitats.

The higher abundance and diversity in the coral environments may reflect a higher number of niches available for decapods, shallower water depth, higher oxygen 
content and/or difference in energy levels in the two environments, making coral reefs a more suitable environment for decapods. 


\section{GEOLOGY}

General geology of the studied area. -- Central Dobrogea lies on the Moesic Platform and is bounded by major faults (Fig. 1). To the north, the Peceneaga-Camena Fault separates central Dobrogea from the North Dobrogean Orogeny, and to the south the boundary is marked by the Capidava-Ovidiu Fault (SĂNDULESCU 1984).

Central Dobrogea, as a major geological unit, is the result of Neoproterozoic evolution of a large continental mass by thinning or breaking, creating a rift area. After the Baikalian Orogeny (Early to Middle Cambrian), when it suffered its main deformations and became a folded system, Central Dobrogea became tectonically stable (SĂNDULESCU 1984).

Morphologically, central Dobrogea is an eroded surface with small hills and little relief. The maximum elevation, 200 m, is at Altân-Tepe (MUTIHAC et al. 2004). The Casimcea Plateau lies north of Midia Cape - Hârsova where solution of Jurassic carbonate deposits has produced karstic relief with many caves.

The central Dobrogea Massif stands out as a distinct geological unit (Fig. 2). Its primary distinction is the age and the nature of the Precambrian basement and the fact that this basement rock is exposed in outcrops over extended areas. The basement of central Dobrogea consists of low and medium grade schist which is assigned to two 


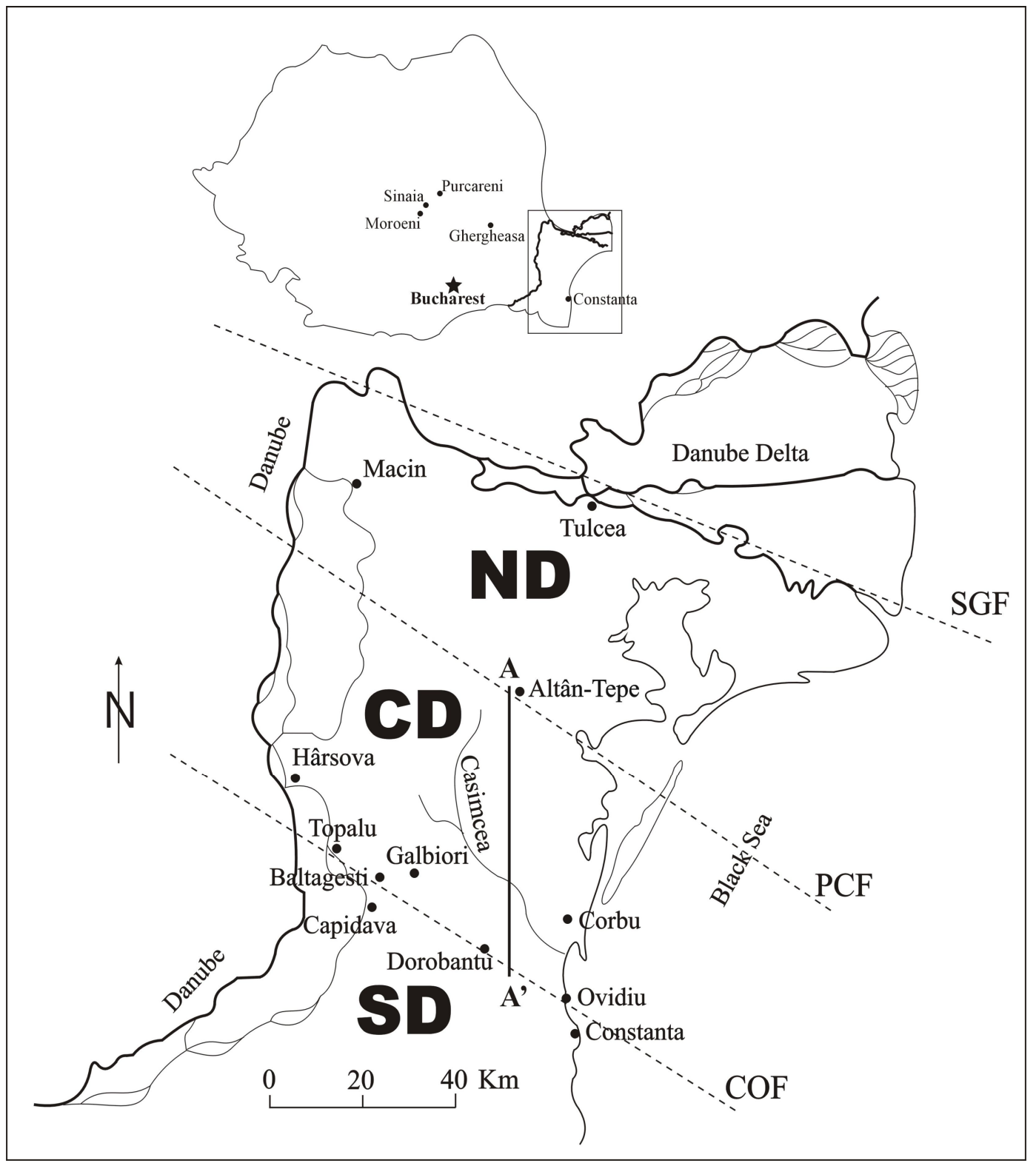

Fig. 1. - Main tectonic units from Dobrogea (modified from HERMANN, in LEINFELDER et al. 1994). ND - North Dobrogea, CD - Central Dobrogea, SD - South Dobrogea, SGF - St. George Fault, PCF - Peceneaga-Camena Fault, COF - Capidava-Ovidiu Fault, A-A' profile in Fig. 2. 
groups differentiated by metamorphic grade and structure: the Ceamurlia Group and the Green Schist Group (IONESI 1994). The Ceamurlia Group is estimated to be $2000 \mathrm{~m}$ thick and has a medium grade metamorphic character. Absolute age analyses have yielded values between 711 and 208 Ma (IONESI 1994). Thus, the schists belonging to Ceamurlia Group are Upper Proterozoic-Paleozoic in age. The Green Schist Group is situated stratigraphically above the Ceamurlia Group and has a thickness estimated to be $5000 \mathrm{~m}$. It is of low metamorphic grade. The age of this group continues to be debated (SĂNDULESCU 1984).

In central Dobrogea, sedimentary rocks are thin and comprise of Jurassic, Cretaceous, and Miocene (Sarmatian) deposits (Fig. 3). Middle Jurassic (Bathonian) strata are the oldest sedimentary rocks to overlie the crystalline basement. They are in term overlain by Callovian-Oxfordian and Kimmeridgian rocks (MUTIHAC et al. 2004).

The most important outcrops with Jurassic rocks in central Dobrogea are aligned on a NW-SE line: Hârsova-Topalu-Băltăgești-Gălbiori in the western area; the Casimcea area in the central-eastern part; and Dorobanţu-OVIDIU in the south-eastern part (DRAGASTAN et al. 1998).

Lithostratigraphy of the Jurassic deposits in central Dobrogea. -- Jurassic deposits from central Dobrogea are Middle Jurassic (Upper Bathonian-Callovian) and Late Jurassic (Oxfordian-Kimmeridgian) in age. These deposits represent the base of the sedimentary suite in central Dobrogea. They lie directly over the strongly folded Green Schists of the basement. 


\section{N}

North

Dobrogea

Altan-

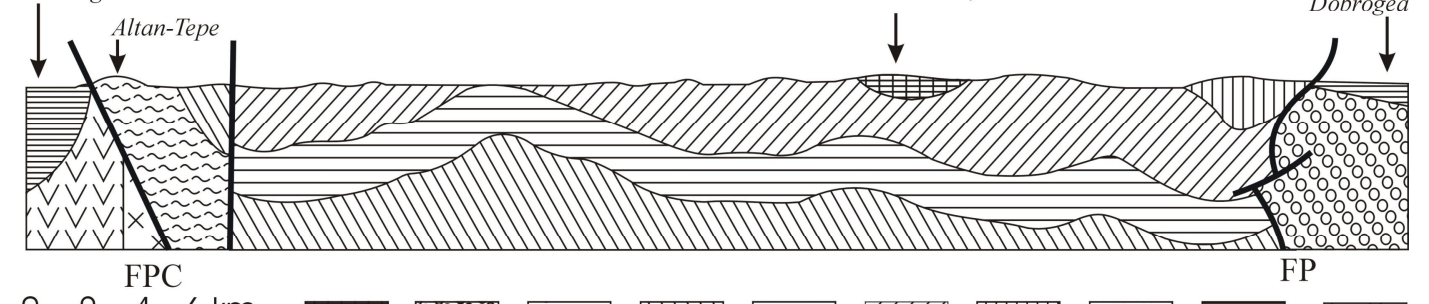

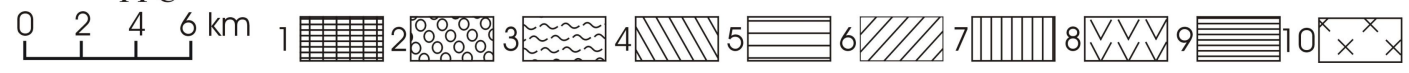

Fig. 2. - Geological section through central Dobrogea (modified from MUTIHAC et al.

2004). Legend: 1- Jurassic; 2- South Dobrogea Basement; 3- Altân-Tepe Schists; 4-

infragraywacke; 5- lower graywacke; 6- upper graywacke; 7- supragraywacke; 8-

Paleozoic; 9- Triassic; 10- Rhyolite; FPC - Peceneaga-Camena Fault; FP - Palazu Fault. 
In central Dobrogea, the Jurassic section has been divided into three formations: Tichileşti Formation, the Gura Dobrogei Formation, and the Casimcea Formation (DRAGASTAN et al. 1998). The following is a brief outline of the stratigraphy of the Tichileşti and Gura Dobrogei formations and a more detailed stratigraphy for the Piatra and Topalu members of the Casimcea Formation. The decapod faunas were collected from these two members.

The Tichileşti Formation was described by DRĂGĂNESCU and BEAUVAIS in 1985. The Tichileşti Formation corresponds to what previously was called "Basal Detrital Horizon" or "Sandy-Conglomeratic-Calcarenite Series". The thickness varies from 0-35 $\mathrm{m}$, due to sedimentation hiatuses at the base, to post-depositional erosion at the top, and to condensation. Analyzing the sedimentation rate, DRĂGĂNESCU and BEAUVAIS (1985) recognized two different types of sequences: normal sequences and condensed sequences. The Tichileşti Formation represents a distinct sedimentation cycle deposited during a transgression over the green schist basement. The upper part is separated from younger Jurassic deposits by a lithological discontinuity and a stratigraphic unconformity. This formation consists of sands, conglomerates, calcareous sandstones with pebbles of green schist and quartz, an alternation of marls and calcarenite, sandy limestone, nodular limestone, calcareous sandstone with cross bedding (only in the western part of central Dobrogea), and encrinal limestone with siliceous bands.

The Gura Dobrogei Formation, also known as the Middle Jurassic Encrinal Formation (DRĂGĂNESCU 1971), is discordant and transgressive over the green schist 


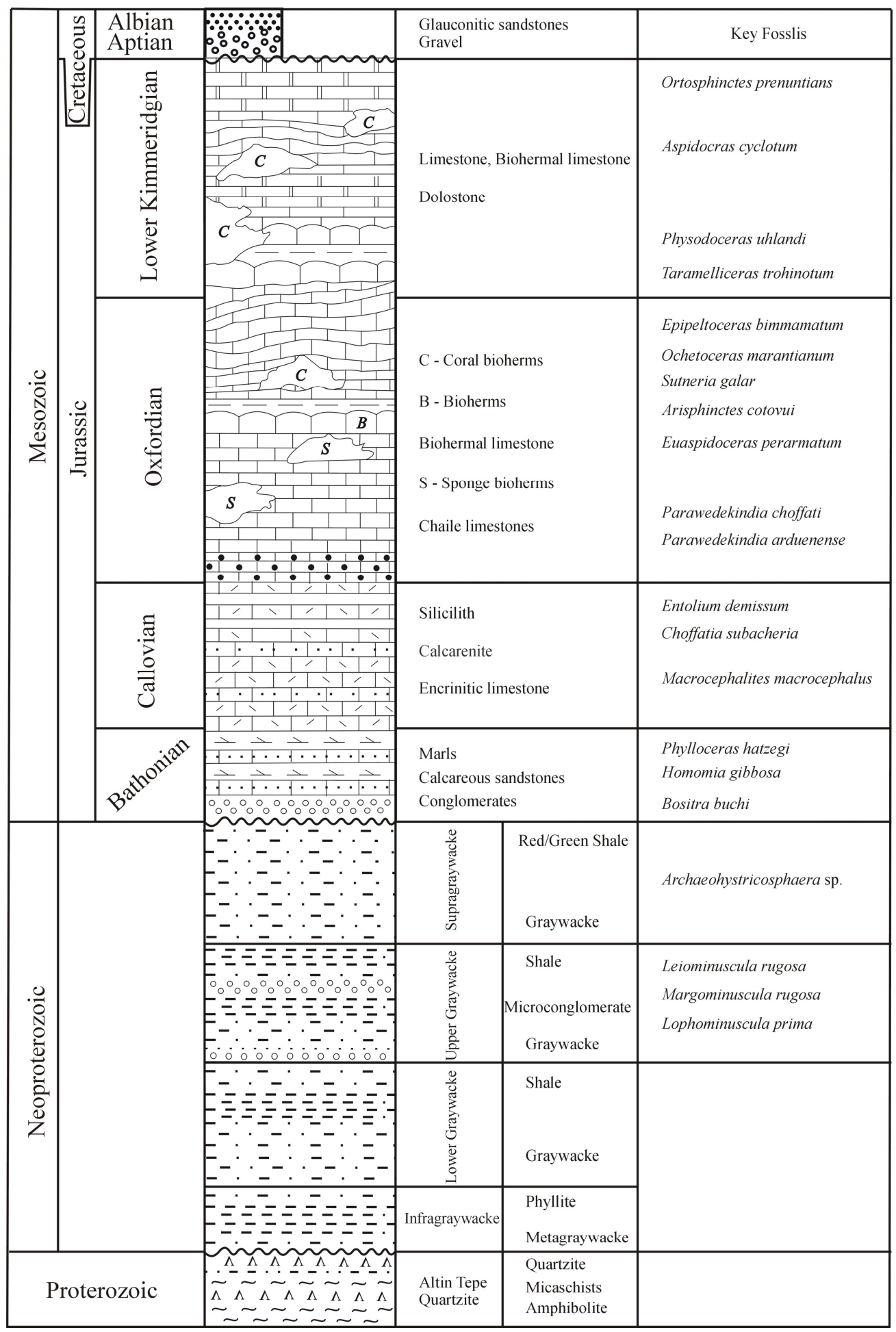

Fig. 3. - Stratigraphic chart for central Dobrogea, (redrawn after MuTIHAC et al. 2004). 


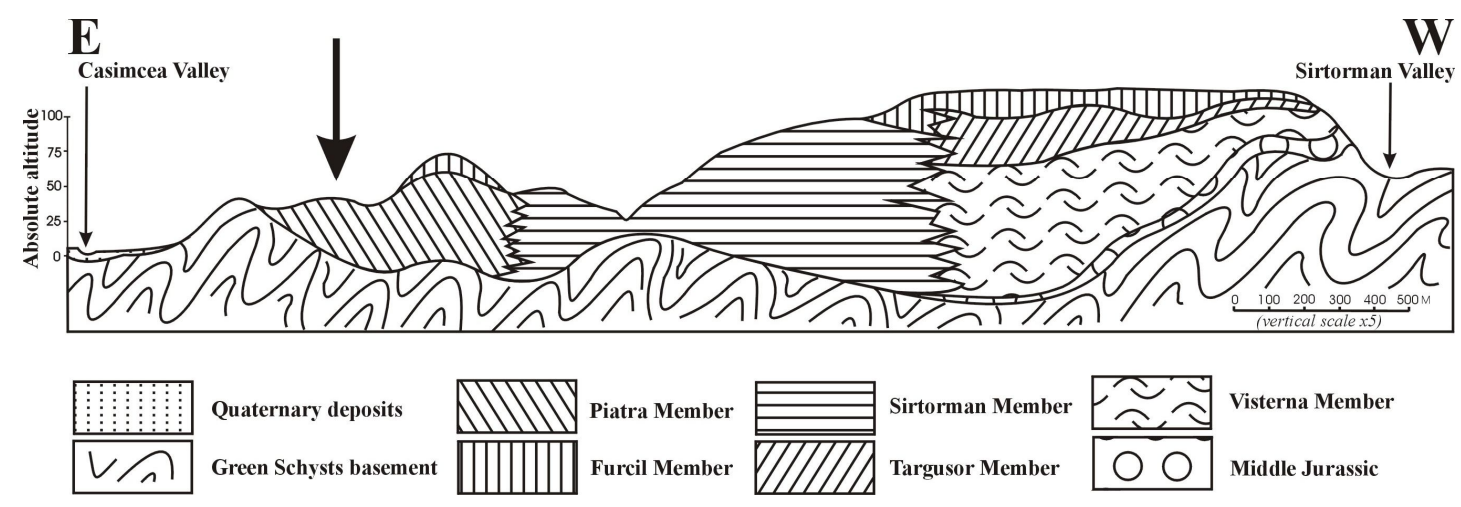

Fig. 4. - Geologic section through the central part of the Casimcea Syncline (from Dragastan et al. 1998); arrow points to the Piatra Member. 
basement or over the Middle Jurassic deposits. At the top, and separated by a paraconformity and a lithologic discontinuity, are early/middle Oxfordian deposits. This formation consists of bio-spar calcarenite with crinoid fragments, echinoid plates and spines, and very rare fragments of epibenthic bivalve. The intergranular material is usually sparite or micrite, in variable quantities. Some silt-sized, angular, quartz grains are also present. The thickness of the Gura Dobrogei Formation is estimated to be between 12 and $15 \mathrm{~m}$. The formation shows decimeter scale stratification. The age of the Gura Dobrogei Formation is middle-late Callovian (DRĂGĂNESCU 1971), which was established on the basis of stratigraphic position.

The Casimcea Formation is the third major lithostratigraphic unit in central Dobrogea (DRĂGĂNESCU 1976) (Fig. 4). This formation is more important to this study than the other two due to its spatial extent, thickness, lithofacies complexity, and variable fossil content content. It has been estimated that the Casimcea Formation has a thickness of 150-500 $\mathrm{m}$. This formation is dominated by skeletal limestone (bio-accumulated and bio-constructed). In the upper part, minor lagoonal micritic limestone and rare dolomites are present. Based on ammonite biostratigraphy, the Casimcea Formation has been dated as middle Oxfordian to Kimmeridgian (ANASTASIU 1898; SIMIONESCU 1907, 1910; PAtrulius \& OrghidAn 1964; BĂRBUlescu 1969, 1970, 1974, 1979; ChiriaC et al. 1977).

DRĂGĂNESCU (1976) separated seven lithological facies that correspond to four groups assigned to four petrographic systems. He also distinguished eight members 


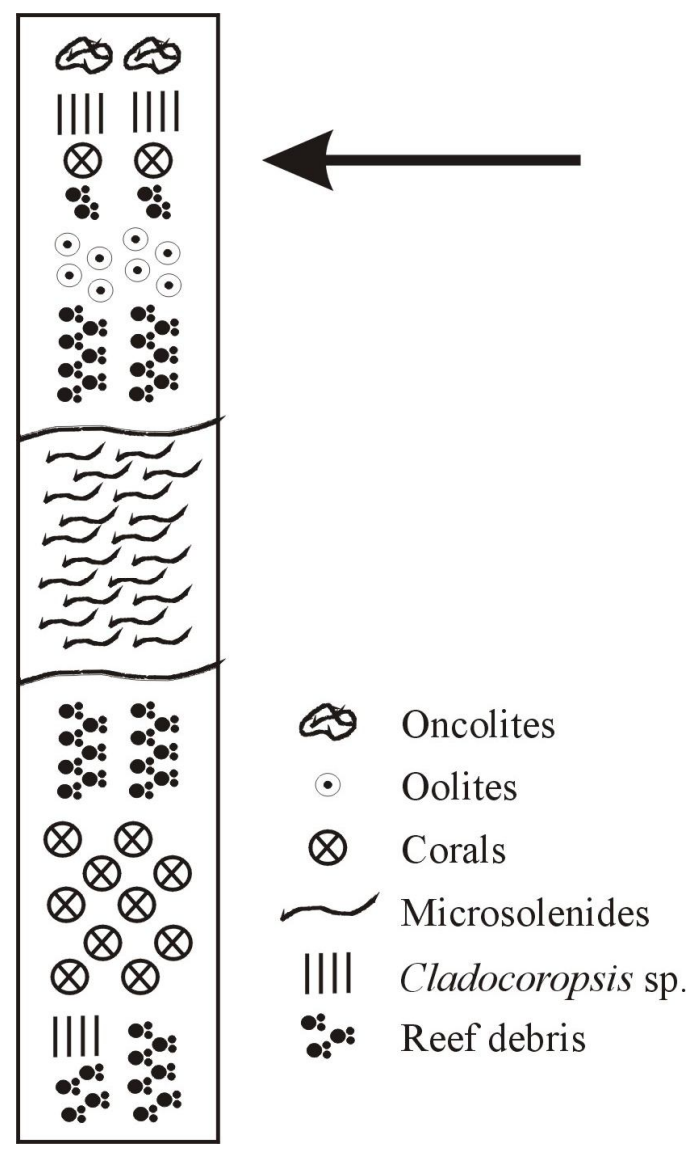

Fig. 5. - Simplified stratigraphic column from the Piatra quarry (after HERMANN, in LEINFELDER et al. 1994). Arrow indicates the coral-rich level where decapods have been collected, vertical scale is approximately $18-20 \mathrm{~m}$. 


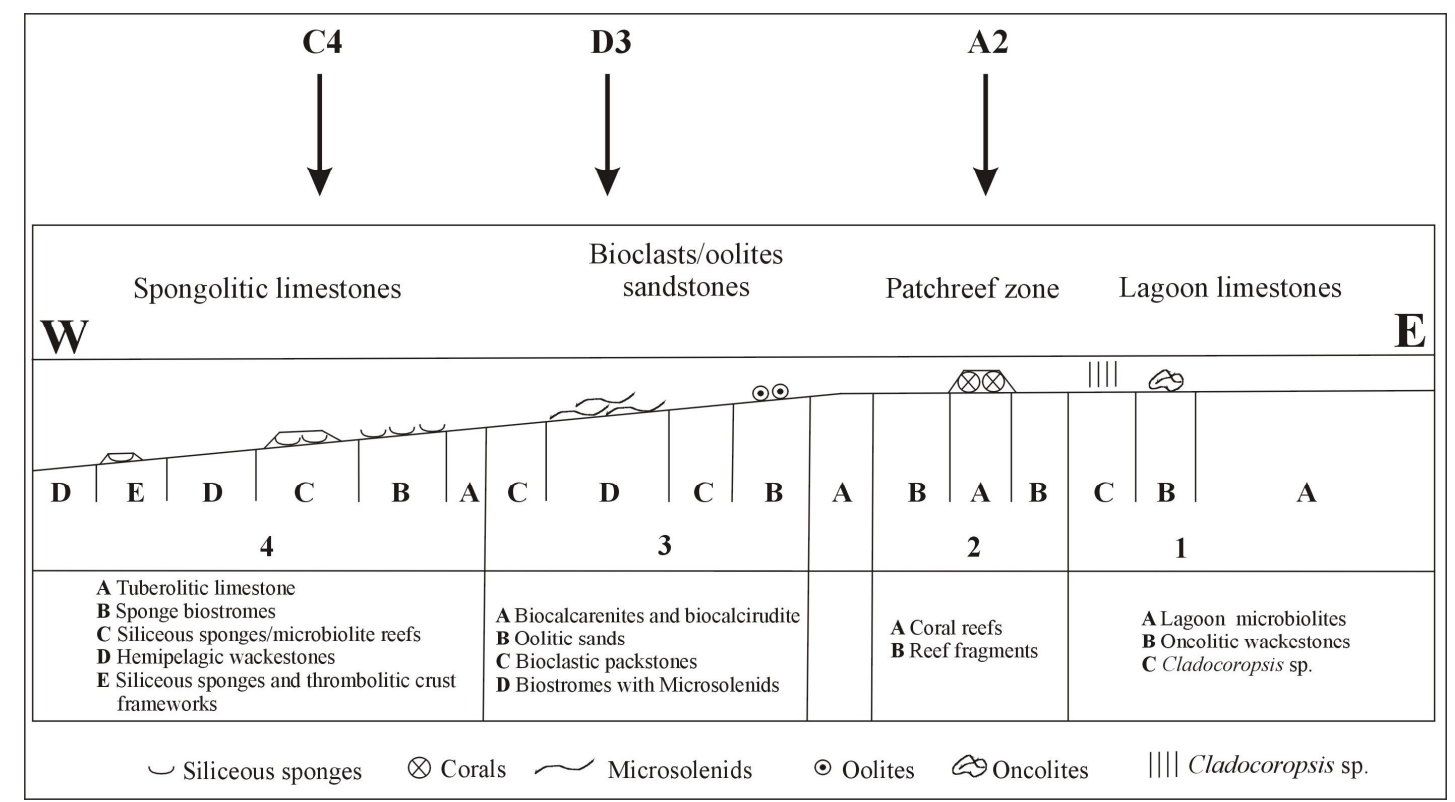

Fig. 6. - Facies distribution on the carbonate ramp of central Dobrogea (modified from HERMANN, in LEINFELDER et al. 1994). A2 - coral reef zone; D3 - biostromes with microsolenids; $\mathrm{C} 4$ - sponge reef zone. 
which were described in 1976, the Visterna Member (sponge-algal bio-constructed series), Târguşor Member (sponge-algal triturated series), Cechirgea Member (stromatolite-algal series), Sârtorman Member (corpuscular-algal series), Piatra Member (lower coralgal bio-constructed series), Topalu Member (upper coralgal bio-constructed series), Furcil Member (corpuscular coralgal series), and the Luminiţa Member (lagoonal micrite series).

The Piatra Member crops out in the eastern part of central Dobrogea. The type section is situated between Sârtorman Valley (South of Palazu Mic) and Piatra (Fig. 5) on the eastern banks of Taşaul Lake. The thickness of this member is 20-30 m. It consists of tabular sequences of lamellar coral colonies and biolithites of pseudostromata. The Piatra succession consists of a complex array of coralline limestone. Two coralgal/algal biostromal sequences are present separated by 3-4 m of granular biodetrital coralliferous limestone. Coral colonies that comprise these coral-rich sequences are of multiple types: lamellar, parallel, meandering, and branching. Frequently the branching type is associated with small subspherical polyps and robust branching types (Fig. 10) (DRAGASTAN et al. 1998).

When the diversification of coral colony types increases, the algal and skeletal "allochem" quantity also increases. Hydrozoans, crinoids, and various large bivalves are part of the associated fauna, and, in the upper part, diceratid bivalves are also present (DrAGASTAN et al. 1998). 

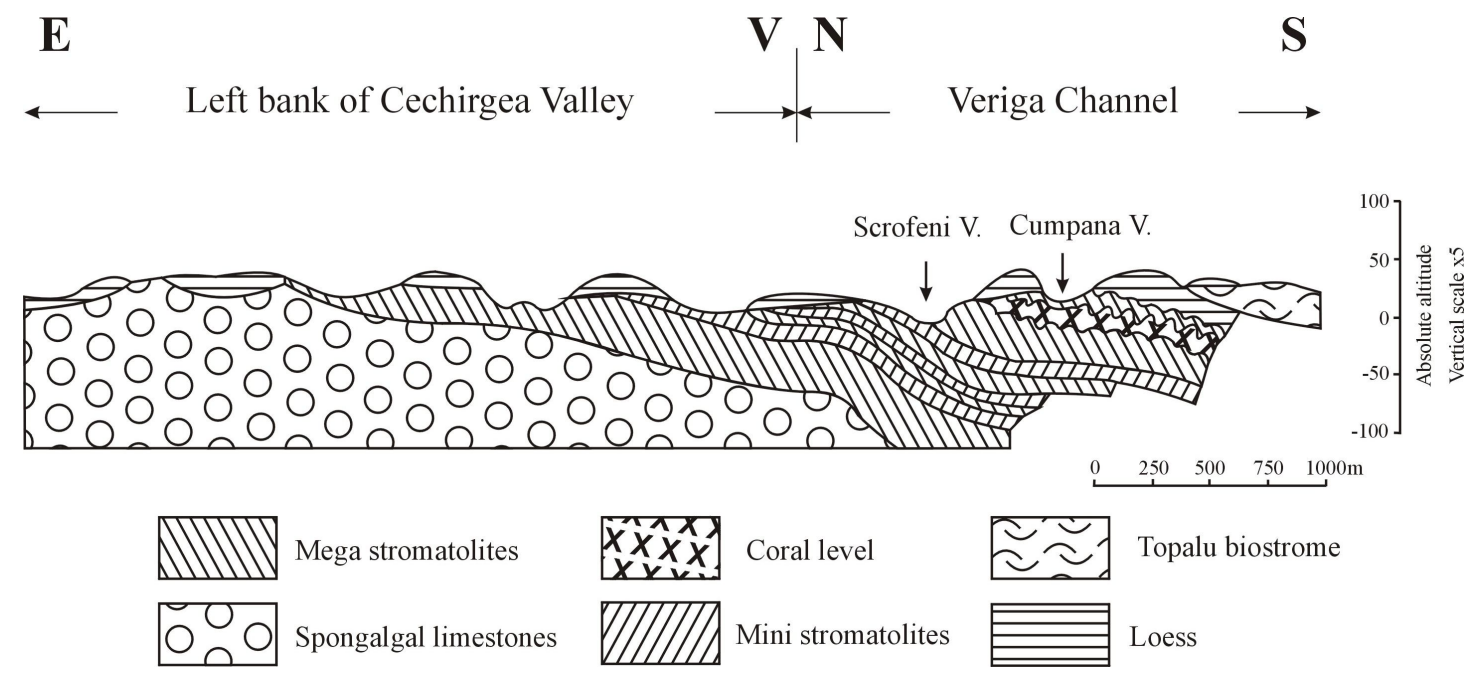

Fig. 7. - Geological section along the left bank of Cechirgea Valley and Veriga Channel on the right bank of the Danube (modified from DRĂGĂNESCU 1976). 


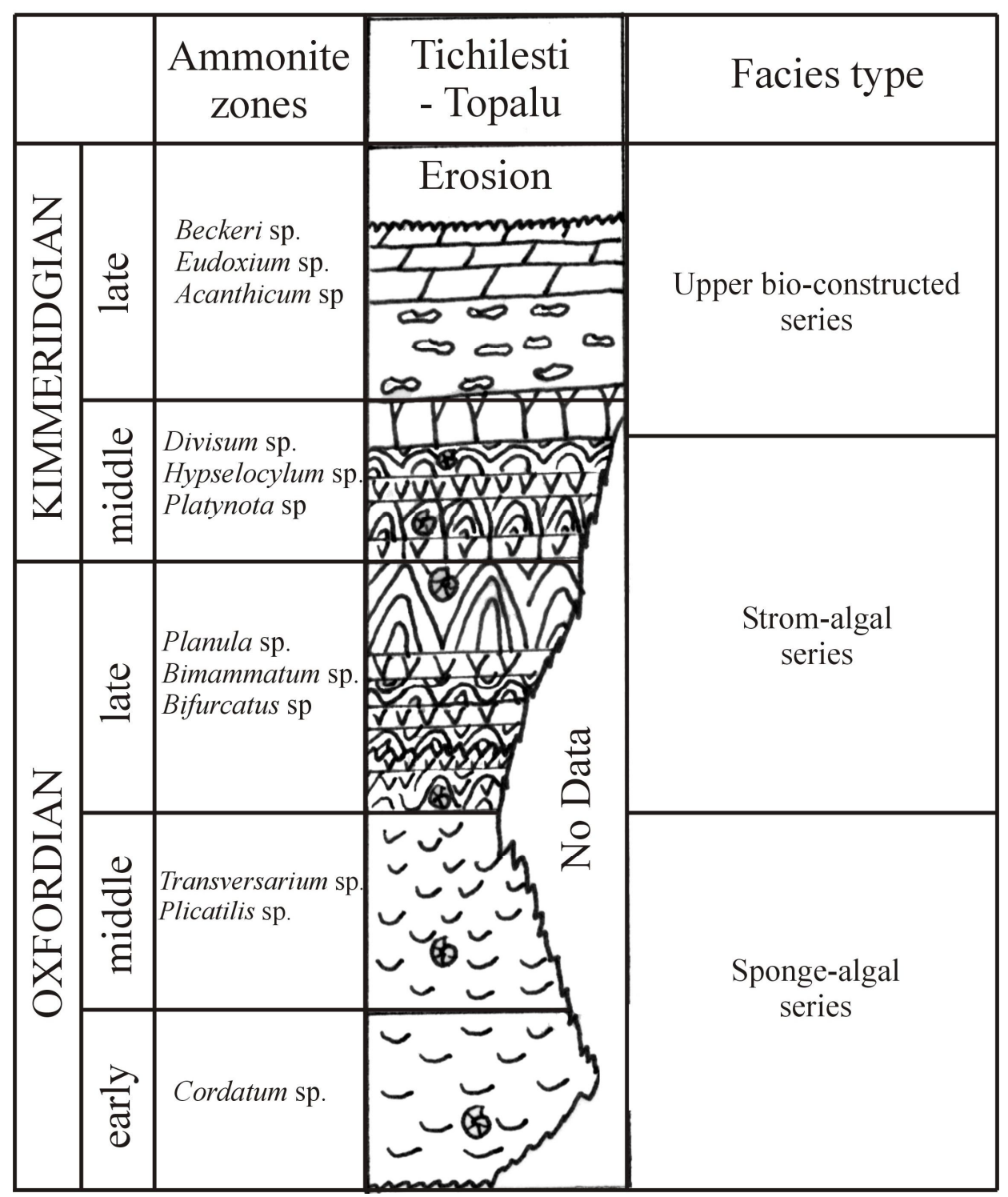

Fig. 8. - Simplified stratigraphic column and facies types for Tichileşti - Topalu area (modified from DRĂGĂNESCU 1976). 
Analyzing the depositional settings, DRĂGĂNESCU (1976) recognized that the algal masses and coral crusts were barriers in the patch reef environment. HERMANN (in LEINFELDER et al. 1994), studied the types of microbial crusts. She placed these biostromes with microsolenids from the eastern part of central Dobrogea in the oolitic, bioclastic sandstones to the east of the sponge-rich limestone (Fig. 6, D3).

The existence of this intermediate facies makes it possible to correlate the coralliferous limestone (Fig. 6. A2) with the sponge-rich limestone (Fig. 6. C4) to the west. BĂRBULESCU (1971), mentioned that toward the west, on the eastern slope of Sârtorman Hill, corals become scarce and occured only as fragments associated with other types of organisms, especially echinoderms. Further to the west numerous encrusting organisms, probably detached from the sponges, have been found in bioclastic limestone. The associated fauna, including the corals, are species with large stratigraphic ranges. Overall, they indicate a middle to late Oxfordian age.

The Topalu Member is a coral-bearing facies that crops out in the western part of Central Dobrogea, north of Topalu; on the Veriga Channel (Fig. 7), south of Topalu village to Capidava; and on the Danube tributary valleys as small outcrops in Alsăneşti Valley, Calachioi, and Coada Zăvălanului south of Topalu. The type section of this member consists of about 12-20 m of reef structures that crop out at Topalu for about a kilometer along the Veriga channel. The reefs immediately south of Topalu are above the last level of the stromatolitic/algal facies, underlying limestones from the pseudostromatolitic subfacies (Fig. 8) (DRAGASTAN et al. 1998). 

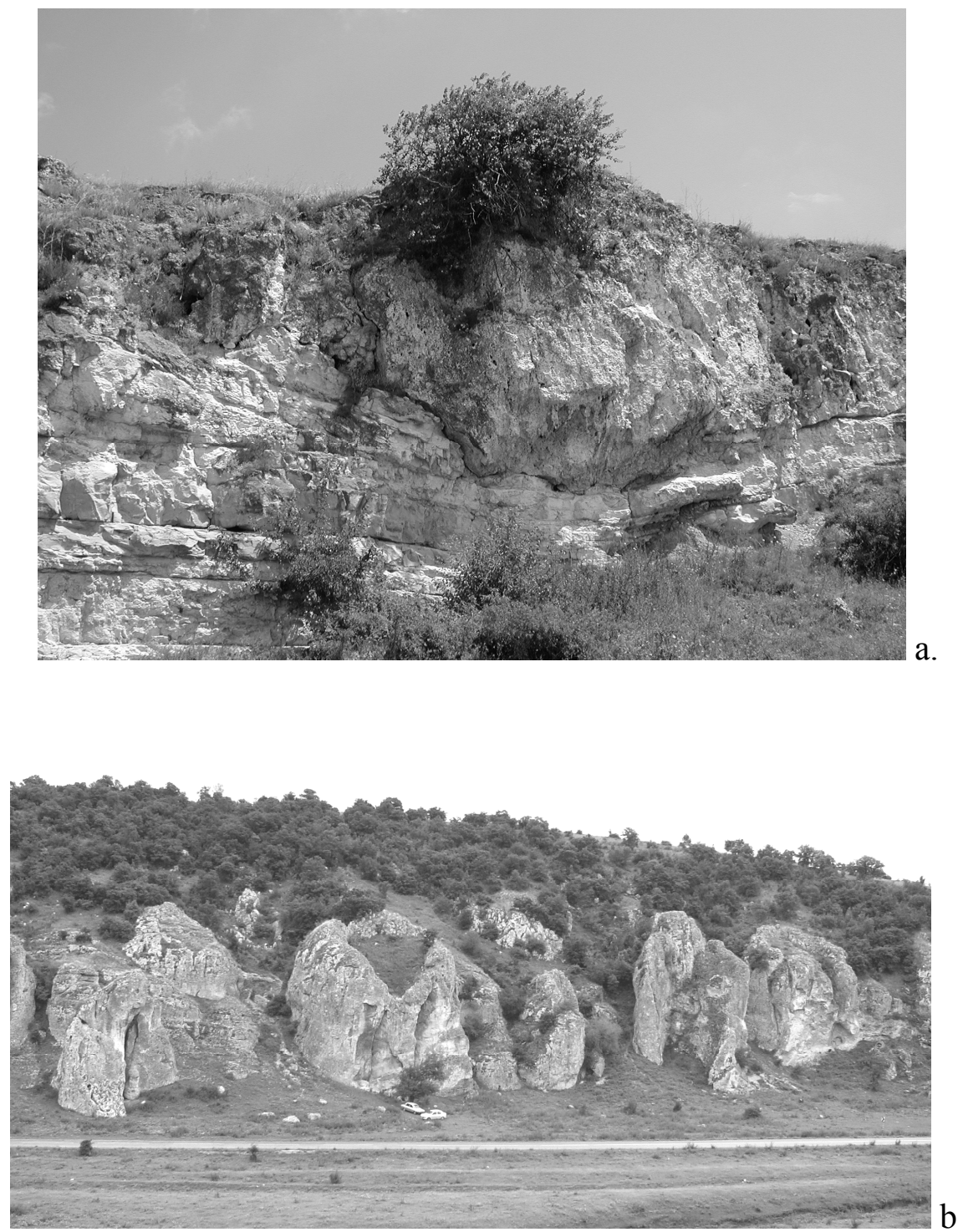

Fig. 9. - Outcrop images from Topalu and Cheia; a. Bioherm and associated biostromes at Topalu (photo by OVIDIU FRANȚESCU); b. Ring-shaped sponge reefs at Cheia (photo by RODNEY FELDMANN). 


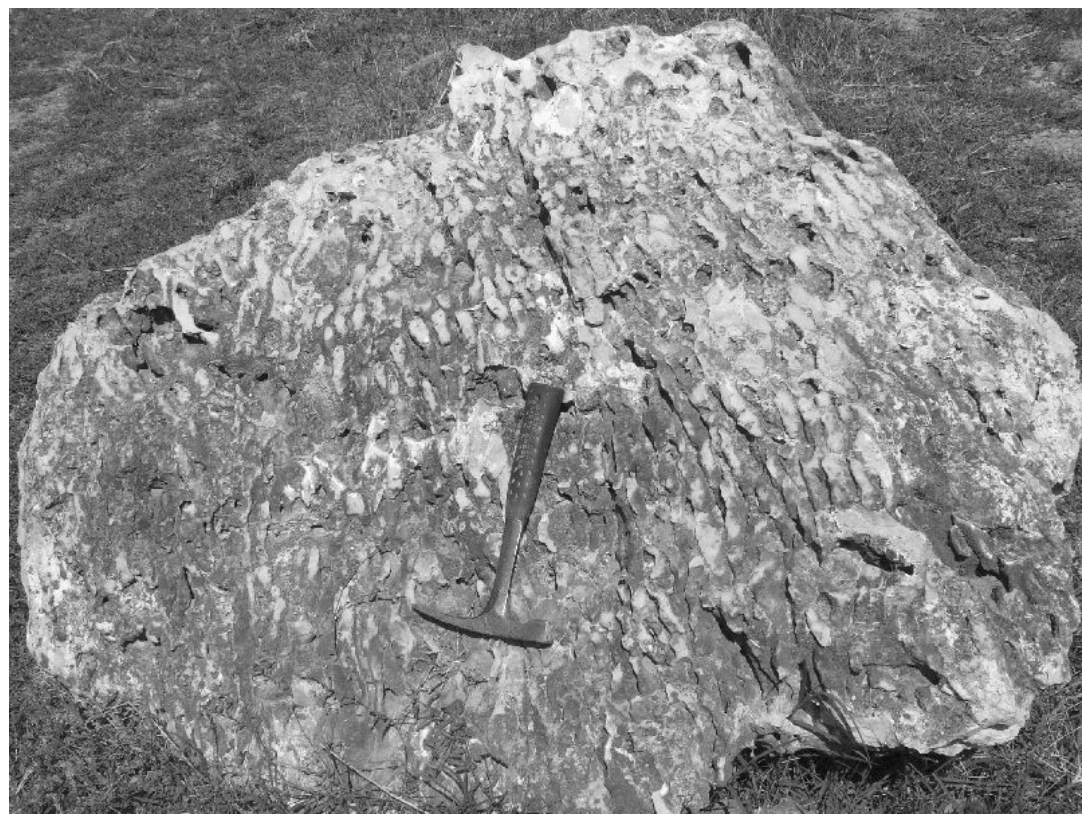

Fig. 10. - Branching coral colony at Topalu (photo by OVIDIU FRANŢESCU). 
North of Topalu, this section is represented by a large number of patch reefs (Fig. 9) and coral colonies that are linked by a continuous biostrome. The base of this reef complex is undulatory, just like the other coralliferous strata from the stromatolitic/coralliferous complex. The undulations are due to differential compaction under the weight of the larger coralliferous bio-constructions (Fig. 9) (DRAGASTAN et al. 1998).

Branching colonies (some of them more than a meter in diameter Fig. 10) are predominant but there are also lamellar/sub-massive colonies, as well as sub-spherical and some conical or cylindrical solitary polyps.

In addition to the coral associations, some other groups of colonial organisms have been described from this section: chetetids (Blastochaetetes capilliformis DIETRICH 1919, Ptychochaetetes sp.) and hydrozoans (Actinostromaria tokadiensis YABE \& SugIYAMA 1935; Hudsonella dobrogensis TURNSEK \& BăRBULESCU 1969; Mileporidium remesi STEINMANN 1903; Shuqraia heibroeki HUDSON 1954) (TURNSEK \& BĂRBULESCU 1969).

In some parts of the reef there are large thick-shelled bivalves (Trichitites sp., Ctenostreon sp.), numerous bivalves with high umbo (Opisoma sp.), and many pectinid and lithophagous bivalves.

Generally, coralliferous bio-constructions from Topalu and Hârsova (La Vii Hill) are from the same type of deposits (microgranular limestone with fine detrital organic fragments, often micritized). These limestones may have a hard compact form or can be soft and chalky. 
The age of the Topalu Biostrome can be determined only by its stratigraphic position. In the highest stromatolitic level, the ammonite fauna is limited but allows dating to the fourth, early Kimmeridgian coralliferous level. This coralliferous biostrome lies on limestone with Ataxioceras sp. and Physodoceras sp.

The pseudostromatolitic complex, situated above these coralgal limestones, south of Topalu, is not known to contain any paleontological elements that can indicate an age younger than early Kimmeridgian.

The Topalu association is one of the richest in Europe (RONIEWICZ 1976), except for the associations from the Jura and Western Carpathians at Stramberk. The richness of the fauna from this outcrop is representative of the late Oxfordian and early Kimmeridgian from Dobrogea. 


\section{METHODS}

The material presented in this paper was collected from the outcrops using rock hammers and chisels, then packed with a protective layer of paper tissues and brought in to the prep-room, where, after washing and drying, the specimens were prepared using a Micro-Jack@ (airscribe). The Micro-Jack was the least invasive, yet most efficient and effective, method of preparing the specimens. Where needed the specimens where treated with glyptol in order to strengthen them. Steinkerns were used to make casts using Exaflex@ molding compound.

After preparation, specimens were classified using standard terminology for carapace regions and grooves (Fig. 11). The specimens were photographed using a Leica microscope fitted with a digital camera and Spot Advanced software. Specimens were measured relative to the axis shown in (Fig. 12), and full tables of measurements can be found in Appendix.

Some of the specimens are well preserved and allow a detailed description and classification, and other specimens are poorly preserved or are fragments. They cannot be described and classified accordingly. 


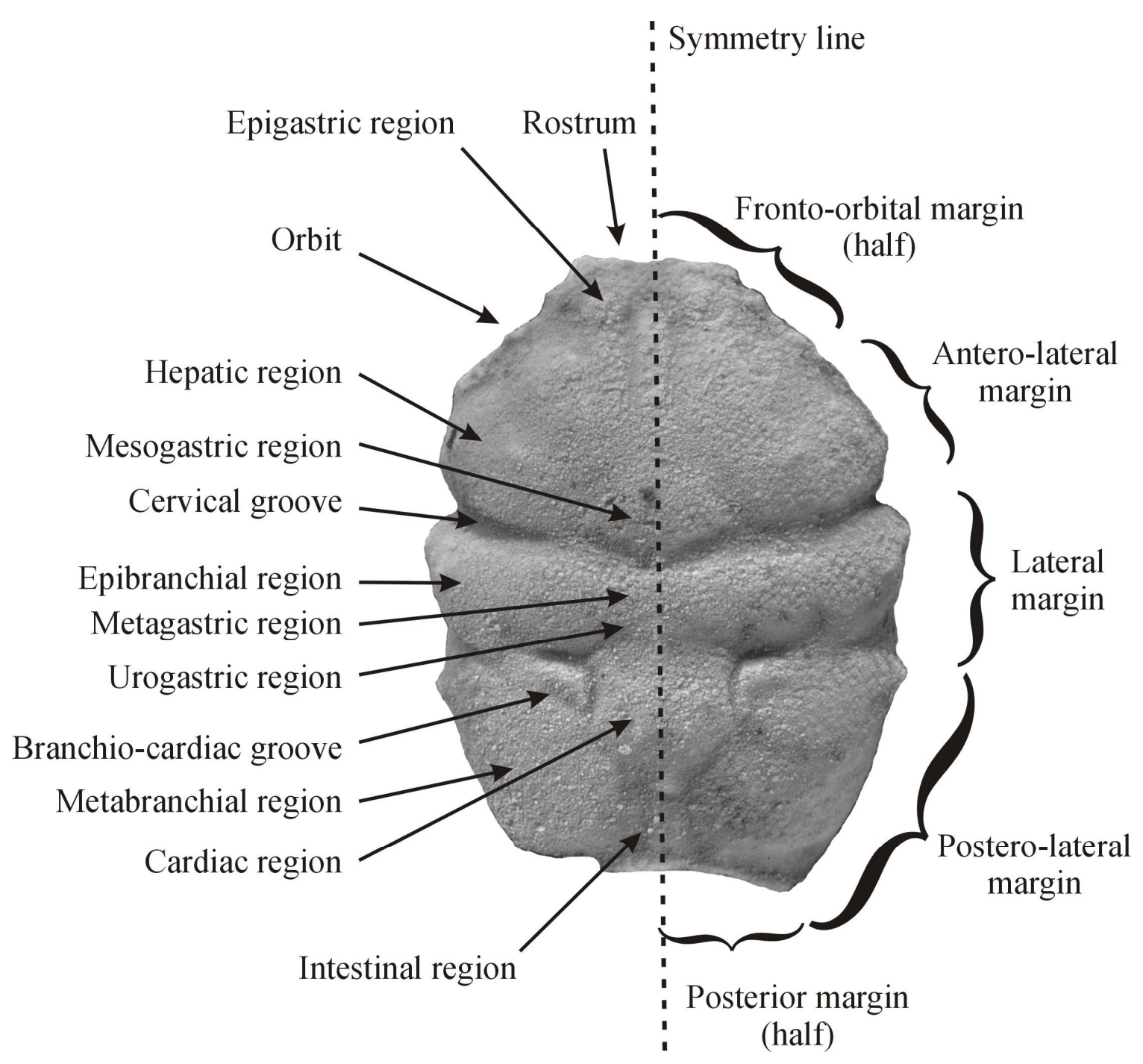

Fig. 11. - Diagram showing standard terminology used to describe decapod carapaces. 


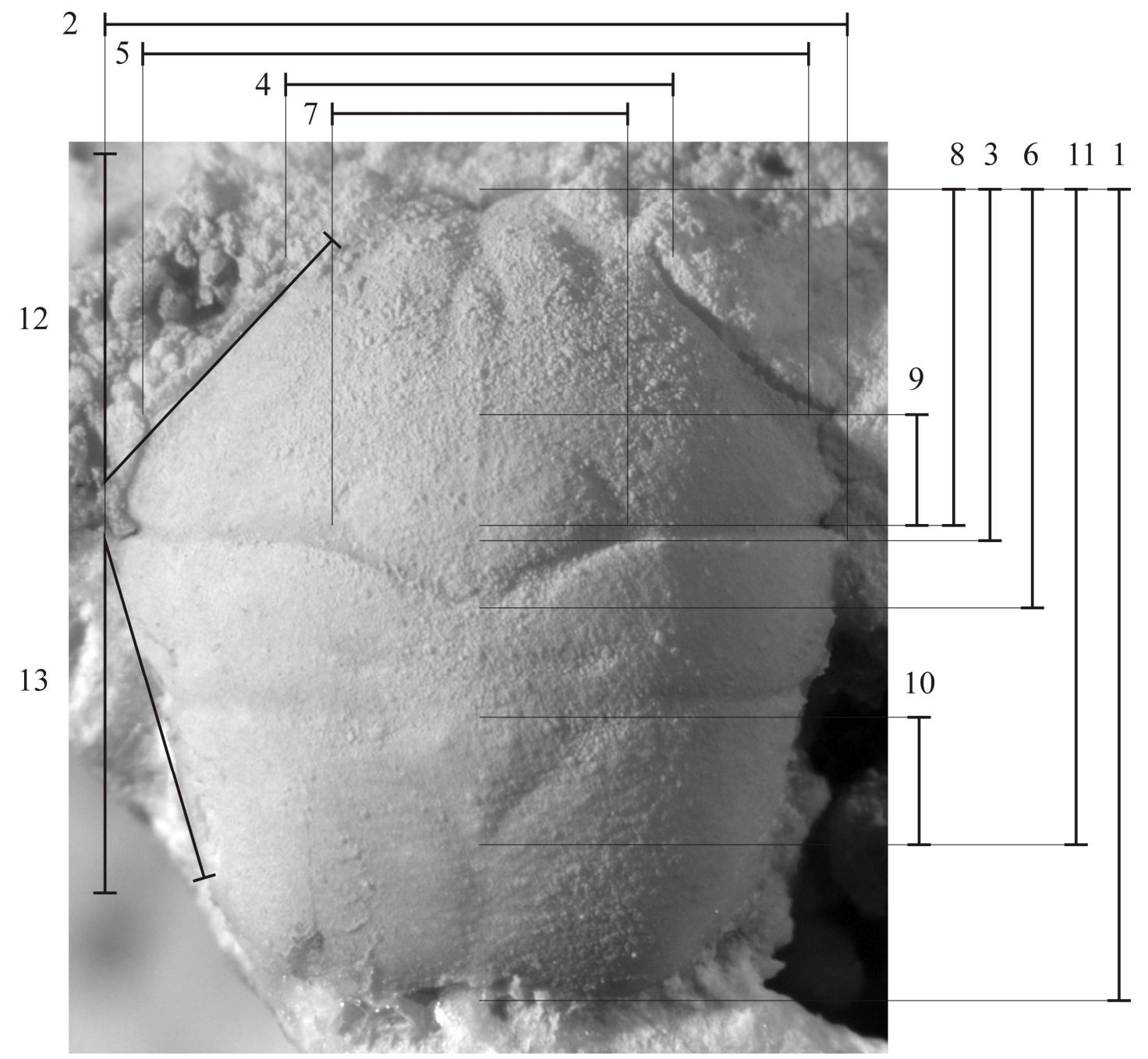

Fig. 12. - Principal axes used for measurements. 1. L-Length, 2. W-Width, 3. MWDMaximum width distance from front, 4. FW-Frontal margin width, 5. FOW-Frontoorbital width, 6. MGRD-Metagastric region distance from front, 7. MGRW-Metagastric region width, 8. CGD-Cervical groove distance from front, 9. OOSD-Outer orbital spine distance from cervical groove, 10. CRL-Cardiac region length, 11. CRD-Cardiac region distance from front, 12. OA-Orbital angle with longitudinal axis, 13. LA-Lateral margin angle with longitudinal axis. 


\section{SYSTEMATIC PALEONTOLOGY}

Phylum Arthropoda LATREILLE 1802

Class Malacostraca LATREILLE 1802

Order Decapoda LATREILLE 1802

Infraorder Brachyura LATREILLE 1802

Superfamily Homolodromioidea ALCOCK 1899

Family Goniodromitidae BEURLEN 1932

Genus Goniodromites REUSS 1858 [imprint 1857]

Ty p e species: Goniodromites bidentatus REUSS 1858 [imprint 1857], p. 12.

Included species: Goniodromites bidentatus ReUSs 1858; $G$.

aliquantulus SCHWEITZER, FELDMANN \& LAZĂR 2007; G. cenomanensis (WRIGHT \& COLLINS 1972), as Pithonoton; G. dentatus LÖRENTHEY in LÖRENTHEY \& BEURLEN 1929; G. laevis (VAN STRAeLEN 1940), as Iberihomola; G. polyodon ReuSs 1858; G. serratus BEURLEN 1929; Goniodromites n. sp. herein.

D i a g n o s i s: "Carapace somewhat longer than wide, as long as wide, or wider than long, maximum width ranging from 85 to $105 \%$ maximum length, narrowing anteriorly and posteriorly, reaching maximum width at position anterior to intersection of cervical groove with lateral margin or at outer-orbital spine, about $30 \%$ the distance posteriorly on carapace. Cephalic region, measured from front to cervical groove along 
midline, half or more than half total length. Front bilobed, often broadly so, frontal margins continuous with orbital margin; orbital margin can be serrate, orbital margin at about 52-57 degrees angle to axis, outer orbital angle a well-developed spine; lateral margin usually with spines; posterolateral margin intercepts long axis at about 20-24 degrees angle. Dorsal carapace typically ornamented with tubercles anteriorly and scabrous rows of tubercles or small spines posteriorly. Cervical groove strongly developed, continuous across axis, lateral segment at 80-85 degrees angle to axis. Branchiocardiac groove strongly developed laterally, less-strongly developed axially, continuous across axis, lateral segments of branchiocardiac groove merging posterior to cardiac region and continuing to intersect with posterior margin. Epigastric regions spherical, small; mesogastric region best defined posteriorly, anterior process often only developed near epigastric regions; cardiac region inflated; epibranchial region defined by cervical and branchiocardiac grooves." (SCHWEITZER \& FELDMANN 2008 [imprint 2007], p.123).

Goniodromites polyodon REUSS 1858

Fig. 13.

1858 Goniodromites polyodon REUSS, p.12.

1858 [1857 imprint] Goniodromites polyodon REUSS. - REUSS, p.165.

1859 Goniodromites complanatus REUSS. - REUSS, p. 165.

1858 [imprint 1857] Goniodromites complanatus REUSS. - REUSS, p.165. 
1859 Goniodromites polyodon REUSS. - REUSS, p. 73, pl. 24, fig. 4.

1859 Goniodromites complanatus REUSS. - REUSS, p. 74, pl. 24, fig. 7.

1860 Prosopon polyodon (REUSS 1858). - VON MEYER, p. 201.

1860 Prosopon complanatus (REUSS 1858). - VON MEYER, p. 203.

1924 [imprint 1925] Goniodromites polyodon REUSS. - VAN STRAELEN, p. 352, fig. 160.

1929 Pithonoton (Goniodromites) polyodon (REUSS). - GLAESSNER, p. 328.

2008 [imprint 2007] Goniodromites polyodon REUSS 1858. - SCHWEITZER \& FELDMANN, p. 127 , pl. 2, fig. C.

Description of materia l: Carapace hexagonal, longer than wide, moderately vaulted transversely and longitudinally, point of maximum convexity in middle of mesogastric region, maximum width of carapace in anterior part of epibranchial regions. Carapace traversed by two moderately incised transverse grooves (Fig. 13 a).

Rostrum wide, spatulate, downturned, with shallow, high angle axial incision; anterior part of rostrum rounded; rostrum and orbital margin intersection at low angle, in a smooth transition. Orbital margins straight, very finely serrated upper orbital rim, orbital angle is between $45^{\circ}$ and $55^{\circ}$ to longitudinal axis; orbits are rounded, shallow; augenrest shallow, elongate, separated from orbit by a small vertical ridge (Fig. 13 b); lateral margins of cephalic area straight, parallel with each other, with two outer orbital spines also characteristic for G. bidentatus. Lateral margins between outer orbital spine and branchiocardiac groove straight, posteriorly converging on longitudinal axis, bearing up to four lateral spines. Posterolateral margins rounded, posteriorly converging on 
longitudinal axis at an angle between $12^{\circ}$ and $21^{\circ}$. Lateral and posterolateral margins merge at high angle, with pronounced offset at branchiocardiac groove.

Cervical groove well defined, laterally straight or undulated; median third curved posteriorly defining posterior side of mesogastric region; at connection point of middle third with lateral third two weakly shallow grooves arise and curve anteriorly, defining lateral margins of mesogastric region. Postcervical groove weakly defined as two small segments on median third of carapace, perpendicular to axis. Branchiocardiac groove well developed on lateral third, weakly developed on median third which is strongly curved posteriorly, defining lateral sides of cardiac region, median third ends perpendicular to posterior margin. Cervical and branchiocardiac grooves are approximately parallel with each other.

Epigastric regions comprised of weakly elevated ovoid bulbs, converging anteriorly, separated by sulcus. Mesogastric region transversely ovate, well defined posteriorly by cervical groove, lateral sides defined by two shallow grooves connected to cervical groove; anterior projection weakly defined, reaching epigastric region by anterior process; anterior part of mesogastric region weakly expressed, axially marked by a faint keel. Metagastric region rectangular, transverse to longitudinal axis; well defined by cervical and postcervical grooves. Urogastric region between postcervical groove and cardiac region, weakly developed, defined as two small depressions, perpendicular to axis; same width as metagastric region. Cardiac region triangular, apex oriented posteriorly, may have three tubercles on triangle tips, lateral margins defined by 
branchiocardiac groove, well defined on anterior side and weakly defined on posterior side. Intestinal region poorly defined, small triangular depressed area, apex of triangle oriented anteriorly. Protogastric and hepatic regions not differentiated. Epibranchial regions well defined as slanted rectangles by cervical and branchiocardiac grooves. Mesobranchial and metabranchial regions not differentiated.

Abdomen, venter, and appendages not preserved.

Material ex a mined: Complete list of the twenty specimens examined is in Appendix.

Me a sure ments: Measurements in mm presented in Table 1.

D is cus s io $n$ : The specimens examined have been collected from both localities, Piatra and Topalu, and they have an age range from middle Oxfordian to early Kimmeridgian. Based on their general morphology with carapace longer than wide, position and definition of the regions, and groove pattern, these specimens were placed within Goniodromites. Based on their specific morphological characters, including presence of four spines on the lateral margin, they were placed within G. polyodon. This species has been found in abundance throughout Europe. 

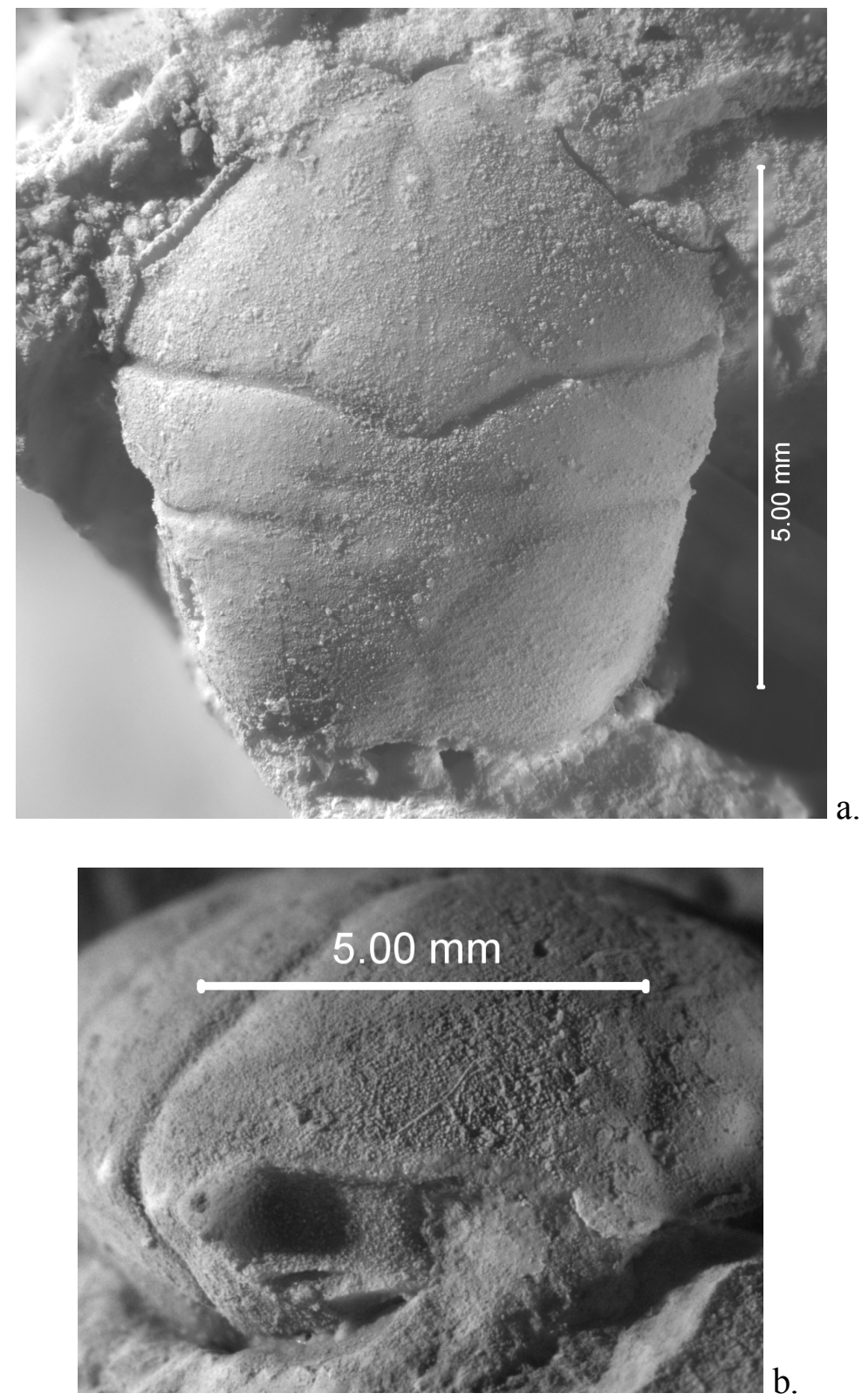

Fig. 13. - Goniodromites polyodon REUSS 1858; a. Dorsal carapace of specimen LPBIIIart-165-16; b. Orbital area detail of specimen LPBIIIart-165-14. 
Goniodromites cf. G. bidentatus REUSS 1858

Fig. 14.

1858 Goniodromites bidentatus REUSS: p.12.

1858 [1857 imprint] Goniodromites bidentatus REUSS. - REUSS, p.165.

1859 Goniodromites bidentatus REUSS. - REUSS, p72, pl. 24, figs 5, 6.

1860 Prosopon bidentatum (REUSS). - VON MEYER, p. 200.

1924 [imprint 1925] Goniodromites bidentatus REUSS. - VAN STRAELEN, p. 354, fig. 161.

1929 Pithonoton (Goniodromites) bidentatus (REUSS). - GLAESSNER, p. 327.

1966 Pithonoton bidentatum (REUSs). - PATRULIUS, p. 512, pl. 31, figs 19, 20.

1969 Pithonoton (Goniodromites) bidentatus (REUSS 1859[sic]). - GLAESSNER, p. R486, fig. 293.3.

1988 Pithonoton bidentatum (REUSS). - WEHNER, p. 87.

2000 Pithonoton bidentatum (REUSs). - MÜller, KROBICKI \& WeHNER, fig. 1D. 2008 [imprint 2007] Goniodromites bidentatus REUSS 1858. - SCHWEITZER \& FELDMAnN, p. 125, pl. 2, fig. A.

Description of material: Left anterolateral part of the carapace preserved. Carapace moderately vaulted transversely and longitudinally, point of maximum convexity in middle of mesogastric region, maximum width of carapace at the posterior anterolateral spine (Fig. 14 a).

Rostrum poorly preserved, appears to be rounded, axially sulcate; rostrum and orbital margin intersection at low angle, in a smooth transition. Orbital margins weakly 
convex, very finely serrated upper orbital rim, orbital angle is $51^{\circ}$ to longitudinal axis; orbits rounded, shallow, augenrest shallow, elongate, separated from orbit by small vertical ridge (Fig. 14 b); lateral margins of cephalic area straight, parallel with each other, with outer orbital spines. Lateral margins partly preserved, posteriorly converging on longitudinal axis. Posterolateral and posterior parts of the carapace not preserved.

Cervical groove well defined, laterally straight; median third curved posteriorly defining posterior side of mesogastric region; at connection point of middle third with lateral third two weakly shallow grooves arise and curve anteriorly, defining lateral margins of mesogastric region. Postcervical groove and branchiocardiac groove not preserved.

Epigastric regions comprised of weakly elevated, circular bulbs separated by sulcus. Mesogastric region transversely ovate, well defined posteriorly by cervical groove, lateral sides defined by two shallow grooves connected to cervical groove; anterior projection weakly defined, reaching epigastric region by anterior process, anterior part of mesogastric region weakly expressed. Epibranchial regions well defined as slanted rectangles by cervical and branchiocardiac grooves. Metagastric, urogastric, cardiac, mesobranchial, metabranchial and intestinal regions not preserved.

Abdomen, venter, and appendages not preserved.

Material examined: One specimen was examined, presented in Appendix. Me a sure ment s: Measurements in mm presented in Table 2. 
$\mathrm{D}$ is c u s s io $\mathrm{n}$ : This specimen was collected at Topalu from rocks with an age range of late Oxfordian to early Kimmeridgian. Even though it is only a fragment the preserved morphology allowed identification of this specimen as belonging to Goniodromites. The way rostrum connects with the orbital margins, in a smooth transition, indicates that this specimen does not belong to Goniodromites n. sp. and the size of the two outer orbital spines makes it different than G. dentatus LÖRENTHEY 1929, that has larger outer orbital spines. Because the specimen does not preserve all the necessary characters to allow a precise species determination, it has been, with reservation, assigned to G. bidentatus. 

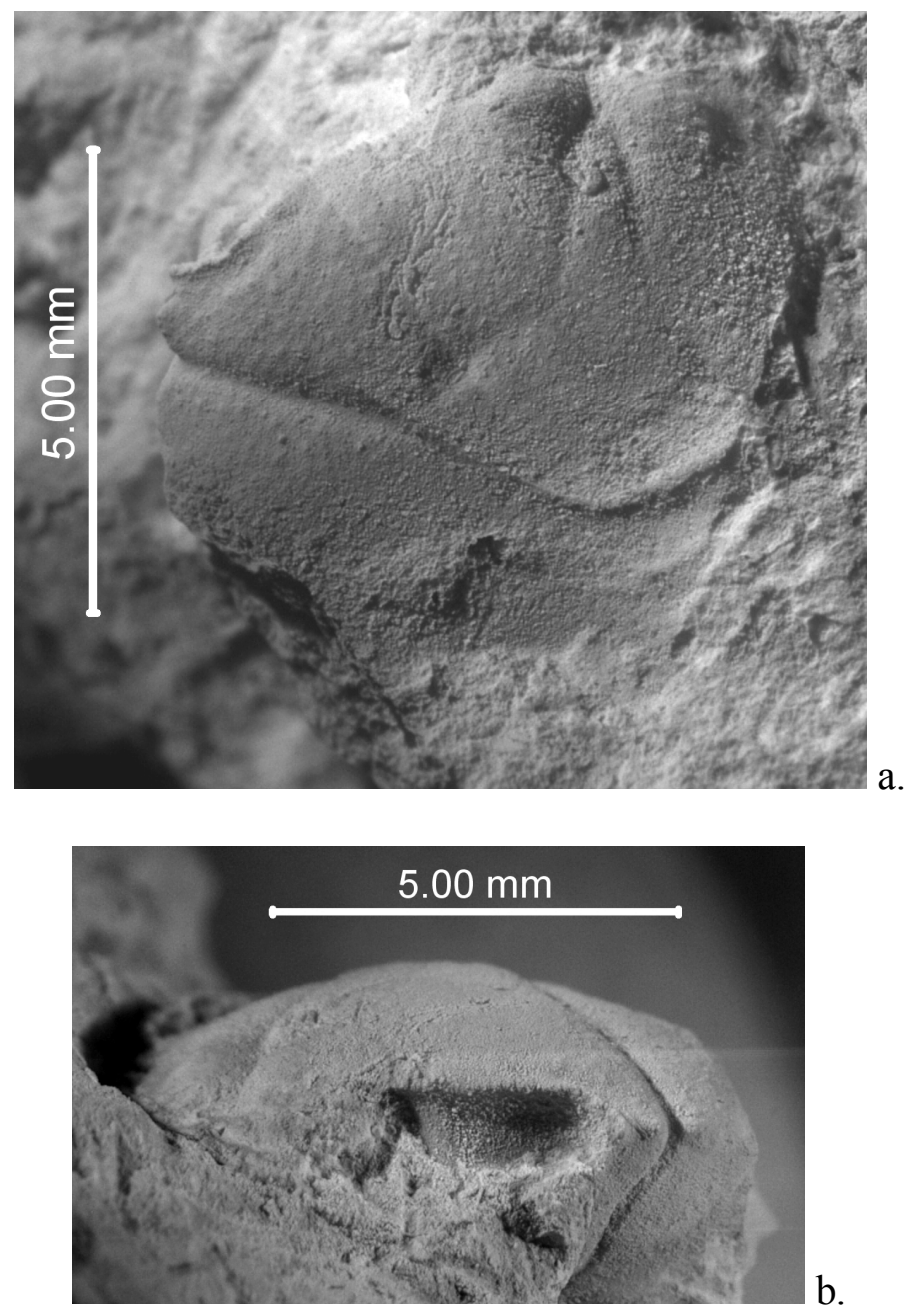

Fig. 14. - Left antero-lateral fragment of Goniodromites cf. G. bidentatus REUSS 1858. Specimen LPBIIIart-166; a. dorsal view; b. orbital area detail. 


\section{Goniodromites n. sp.}

Fig. 15.

D i a g n o s is : Carapace longitudinally ovoid, rostrum broad, spatulate, straight anterior margin perpendicular on axis, with small, shallow indent; rostrum connects with orbital margins at high angle

Description of materia l: Carapace longitudinally ovoid, moderately vaulted transversely and longitudinally, point of maximum convexity in middle of mesogastric region, maximum width of carapace in anterior part of epibranchial regions. Carapace traversed by two transverse grooves, cervical groove well incised, branchiocardiac groove weakly incised (Fig. 15 a).

Rostrum wide, spatulate, downturned, most strongly downturned in mid third, with shallow axial incision; anterior margin of rostrum straight, perpendicular to longitudinal axis; rostrum and orbital margins merge at high angle. Orbital area with augenrest, elongate, moderately deep (Fig. 15 b), with straight margins, very finely serrated upper orbital rim, orbital angle between $41^{\circ}$ and $56^{\circ}$ to longitudinal axis; lateral margins of cephalic area anteriorly converging, with outer orbital spines. Lateral margins between cervical groove and branchiocardiac groove poorly preserved, straight, parallel with longitudinal axis. Posterolateral margins rounded, posteriorly converging on longitudinal axis at an angle between $15^{\circ}$ and $27^{\circ}$.

Cervical groove well defined, laterally straight; median third curved posteriorly defining posterior side of mesogastric region; at connection point of middle third with 
lateral third two weakly shallow grooves arise and curve anteriorly, defining lateral margins of mesogastric region. Postcervical groove weakly defined as two small segments on median third of carapace, perpendicular to longitudinal axis.

Branchiocardiac groove moderately developed on lateral third, weakly developed on median third, strongly curved posteriorly, defining lateral margins of cardiac region, median third perpendicular to posterior margin. Lateral thirds of cervical and branchiocardiac grooves are approximately parallel with each other.

Epigastric region comprised of two slightly prominent ovoid bulbs, oriented and converging anteriorly, separated by sulcus. Mesogastric region transversely ovate, posteriorly well defined by cervical groove, lateral sides defined by two shallow grooves connected to cervical groove; anterior side weakly defined, connecting to epigastric region by anterior process. Metagastric region rectangular, short, perpendicular to axis; well defined anteriorly by cervical groove and posteriorly by postcervical groove. Urogastric region weakly developed, defined as small depression between postcervical groove and cardiac region; same width as metagastric region. Cardiac region triangular, apex oriented posteriorly, lateral margins defined by branchiocardiac groove, well defined on anterior side with traces of two nodes, and weakly defined on posterior side. Intestinal region poorly defined, small triangular depressed area, apex of triangle oriented anteriorly. Protogastric and hepatic regions not differentiated, subhepatic region well defined by antennar groove, not inflated. Epibranchial regions well defined as slanted 
rectangles by cervical and branchiocardiac grooves. Mesobranchial and metabranchial regions not differentiated. Scabrous ornamentation on cuticule.

Abdomen, venter, and appendages not preserved.

T y p e s : LPBIIIart-164-1 - Holotype; LPBIIIart-164-2 - Paratype; LPBIIIart-164-3 Paratype.

Mea surements: Measurements in mm presented in Table 3.

D is c u s s i o n: The specimens have been collected from both localities, Piatra and Topalu, with an age range of middle Oxfordian to early Kimmeridgian. Based on the general morphological characters these specimens have been assigned to Goniodromites but they represent a new species because the overall outline of the carapace is more rounded than for G. polyodon and G. bidentatus, giving it an inflated appearance. The rostrum of Goniodromites n. sp. is broad and has a straight anterior margin which is perpendicular to the longitudinal axis, compared with $G$. dentatus which has rostrum with a rounded anterior margin. The lateral margins of the rostrum of Goniodromites n. sp. are almost parallel with the longitudinal axis, connecting with the orbital margin at a high angle, giving the rostrum a rectangular shape with rounded anterior corners which differs than the outline of the rostrum of G. laevis and G. polyodon. The cephalic region is more inflated than in G. polyodon, and the augenrest is deeper than the augenrest of $G$. polyodon. 

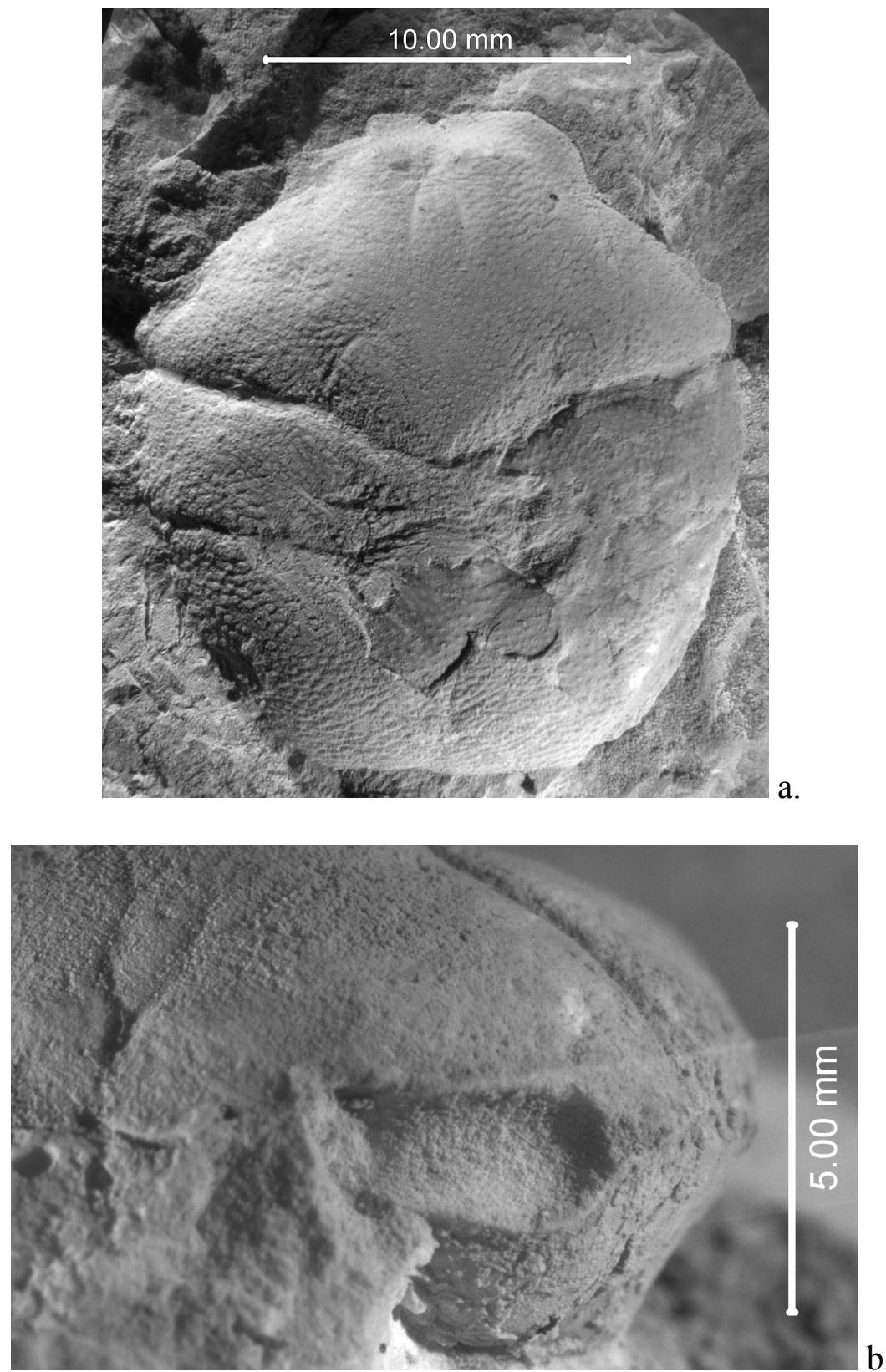

Fig. 15. - Goniodromites n. sp.; a. Dorsal carapace of specimen LPBIIIart-164-1

Holotype; b. Orbital area detail of specimen LPBIIIart-164-3 Paratype. 


\section{Goniodromites sp.}

Material examined: A complete list of the twenty specimens examined is in Appendix.

Me a sure me n t s : Measurements in mm presented in Table 4.

D i s c u s s io $n$ : Twenty fragments of poorly preserved specimens have been examined but which cannot be identified to species level. The few morphological characters that they preserve allowed assignment to Goniodromites sp. The specimens were collected from both localities, Piatra and Topalu, and they have an age range from middle Oxfordian to early Kimmeridgian. Goniodromites sp. is an omnipresent genus within Jurassic rocks throughout Europe. 
Genus Eodromites PATRULIUS 1959

Ty p e s p e c i e s: Prosopon grande VON MEYER 1857, by original designation. In cluded s pecies: Eodromites depressus (VON MEYER 1860), as Prosopon; E. nitidus (A. Milne EdWARds 1865), as Ogydromites; E. polyphemi (GEMMELLARO 1869), as Prosopon; E. rostratus (VON MeYeR 1840), as Prosopon.

D i a g n o s is : "Carapace longer than wide or about as wide in larger specimens, widest just posterior to intersection of cervical groove with lateral margin; orbits oblique, at moderate angle to axis, suborbital margin may extend farther anteriorly than upper orbital margin; rostrum triangular, axially sulcate; lateral margins characteristically convex, especially between intersection of cervical and branchiocardiac grooves with margin, and then narrowing considerably posteriorly; orbits elongate and oblique to axis; cervical groove deep and continuous; branchiocardiac groove deep and discontinuous; mesogastric region with ovate patches of scabrous ornamentation; Subhepatic swelling marked, antennar groove deep, hepatic groove weak." (SCHWEITZER \& FELDMANN, 2007, p. 133)

\section{Eodromites grandis VON MEYER 1857}

Fig. 16.

1857 Prosopon grande VON MEYER, p. 556.

1857 Prosopon grande VON MEYER. - QuenstedT, pl. 95, figs. 41, 43, 44.

1860 Prosopon grande VON MEYER. - VON MEYER, p. 2002, pl. 23, figs. 1-3.

1889 Prosopon grande VON MeYeR. - MOERICKE, p. 67, pl. 6, fig. 21. 
1897 Prosopon grande VON MEYER. - MoERICKE, p. 67, pl. 6, fig. 21.

1895 Prosopon grande VON MEYER. - REMEŠ, p. 203, pl. 2, fig. 12.

1924 [imprint 1925] Prosopon grande VON MEYER. - VAN STRAELEN p. 365.

1925 Prosopon grande VON MEYeR. - BEuRlen, p. 469.

1929 Pithonoton grande (VON MEYER). - GLAESSNER, p. 320.

1933 Pithonoton grande (VON MEYER). - GLAESSNER, p. 180, fig. 1.

1951 Pithonoton grande (VON MeYER). - WiTHERs, p. 175, text-figs. 7-9.

1959 Eodromites grandis (VON MEYER). - PATRULIUS, p. 254.

1966 Eodromites grandis (VON MEYER). - PATRULIUS, p. 509, pl. 30, figs. 10-14.

1980 Pithonoton grande (VON MEYER). - MORRIS, p. 14.

1988 Pithonoton grande (VON MEYER). - WeHNER, p. 91, pl. 7, figs 1, 2.

2000 Pithonoton grande (VON MEYER). - MüLLER et al. fig. 18E.

2008 [imprint 2007] Eodromites grandis (VON MEYER). - SCHWEITZER \& FELDMANN, p. 134, pl. 4, figs. A-G.

Description of materia 1: One poorly preserved specimen. Carapace subrounded, weakly vaulted transversely and longitudinally, point of maximum convexity in middle of mesogastric region, maximum width of carapace at the outer orbital nodes. Carapace traversed by two weakly incised transverse grooves (Fig. 16 a).

Fronto-orbital margin not preserved. Orbits at angle of $56^{\circ}$ to longitudinal axis, elongated, shallow, with outer orbital nodes. Lateral margins between outer orbital node 
and branchiocardiac groove straight, posteriorly converging on longitudinal axis at angle of $16^{\circ}$, deeply incised by cervical groove. Posterolateral margins appear to be rounded.

Cervical groove well defined, laterally slightly concave; median third curved posteriorly defining posterior side of mesogastric region; at connection point of middle third with lateral third, it appears that two weakly shallow grooves arise and curve anteriorly, defining lateral margins of mesogastric region. Postcervical groove weakly defined as two small segments on median third of carapace, converging posteriorly. Branchiocardiac groove poorly developed, median third is strongly curved posteriorly, defining lateral sides of cardiac region. Cervical and branchiocardiac grooves lateral thirds are approximately parallel with each other.

Mesogastric region appearing transversely ovate, posteriorly defined by cervical groove, lateral sides defined by two shallow grooves connected to cervical groove; anterior side poorly preserved, it has a slight tendency to subdivide. Metagastric region rectangular, short and narrow; defined anteriorly by cervical groove and posteriorly by postcervical groove, transverse to longitudinal axis. Urogastric region not developed. Cardiac region weakly defined, pentagonal, apex oriented posteriorly, lateral margins defined by branchiocardiac groove. Intestinal region not preserved. Subhepatic region well inflated, well defined by antennar groove (Fig. 16 b). Epibranchial regions well defined by cervical and branchiocardiac grooves as slanted rectangles, slightly inflated ventro-lateral. Mesobranchial and metabranchial regions not preserved.

Abdomen, venter, and appendages not preserved. 
Materia 1 examined: One specimen was examined, presented in Appendix. Measure me n t s: Measurements in mm presented in Table 5.

D is c u s s i o n: The single specimen was collected from Topalu and has an age within the late Oxfordian to early Kimmeridgian. Even though the specimen is poorly preserved, morphological characters such as the pattern of the grooves, especially the cervical grove; the shape of the lateral margin; the overall shape of the carapace; and the strong inflation of the subhepatic region allowed placement of this specimen in Eodromites. And assigned to $E$. grandis because the specimen has a more rounded outline than $E$. depressus which has the posterolateral margins strongly converging posteriorly. the shape of the cervical groove and the morphology of the lateral margins makes this specimen different from E. rostratus; the shape and the size of the cardiac region separates this specimen from E. polyphemi. 

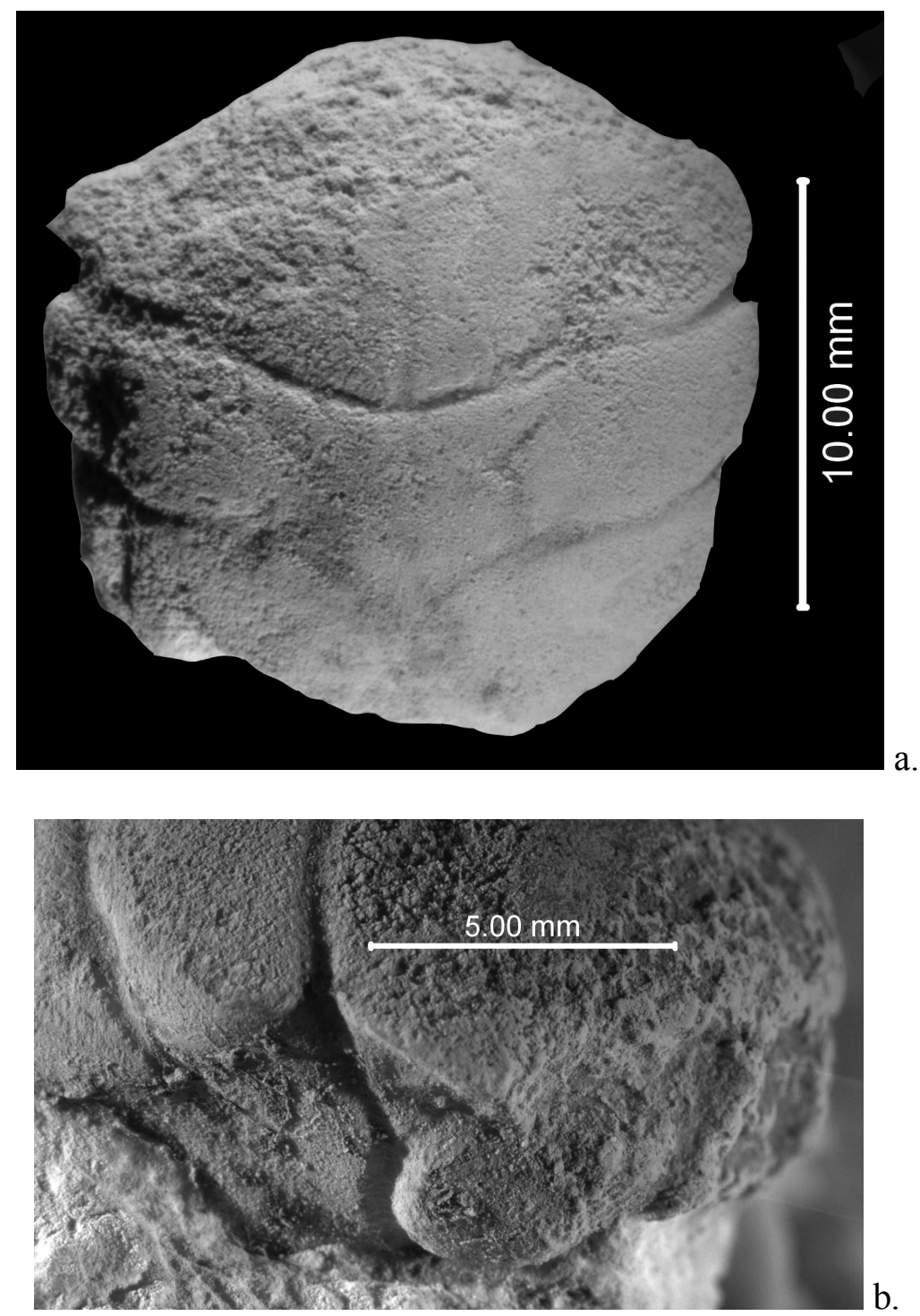

Fig. 16. Eodromites grandis VON MEYER 1857, specimen LPBIIIart-167; a. Dorsal view; b. Anterolateral view showing subhepatic region. 
Family Tanidromitidae SCHWEITZER \& FELDMANN 2008 [imprint 2007] Genus Tanidromites SCHWEITZER \& FeLDMANN 2008 [imprint 2007] Ty p e spe c ies: Prosopon insigne VON MEYER 1857, by original designation. In c luded spe c i e s: Tanidromites etalloni (COLLINS in COLLINS \& WIERZBOWSKI 1985), as Coelopus; T. lingulata (VON MeYer 1858), as Prosopon; T. richardsoni (WoOdWARD 1907), as Prosopon.

D i a g n o s is : "Carapace longer than wide, width about $70 \%$ carapace length, carapace strongly vaulted transversely and longitudinally; lateral flanks strongly developed; regions well-defined, mostly smooth. Rostrum downturned, triangular or possibly truncated at tip, rimmed, axially sulcated, merging into orbital socket; orbital socket directed for ward, rimmed; remainder of orbit weakly concave, oblique, just distal to orbital socket, perhaps for eye to rest in; weak, short lateral ridge extending posteriorly from outer angle of concavity, fromto-orbital width excluding concavity about $60 \%$ maximum carapace width. Lateral margins nearly parallel with one another or converging slightly posteriorly; lateral flanks steep, well defined; sub-hepatic region inflated, bounded ventrally by deep antennal groove, placed well above ventral edge of lateral flank; cervical groove extending onto lateral flanks, merging with united antennar and hepatic grooves (following terminology of Holthuis, 1974). Epigastric, mesogastric, and cardiac regions well-defined; protogastric and hepatic regions not differentiated; cervical and branchiocardiac grooves deep." (SCHWEITZER \& FELDMANN 2008 [imprint 2007], p. 137). 
Tanidromites cf. T. richardsoni WOODWARD 1907

Fig. 17.

1907 Prosopon richardsoni WoODWARD, p. 80, figs. 1, 2.

1929 Pithonoton? richardsoni (WOODWARD). - GLAESSNER, p. 324.

1951 Pithonoton richardsoni (WOODWARD). - WiTHERS, p. 174, text-figs. 1-3, pl. 15.

1980 Pithonoton richardsoni (WOODWARD). - MORRIS, p. 14.

1988 Pithonoton richardsoni (WOODWARD). - WEHNER, p. 69, text-fig. 19.

2007 Tanidromites richardsoni (WoOdWARD). - SCHWEITZER \& FELdMANn, p. 141, pl. 6, fig. K.

Description of materia 1: Carapace ovate, longer than wide, moderately vaulted transversely and longitudinally, point of maximum convexity in middle of mesogastric region, maximum width of carapace in central part of epibranchial regions. Preserved part of carapace traversed by one moderately incised transverse groove. Cephalic area relatively flat. Posterior portion of dorsal carapace, from branchiocardiac groove, not preserved (Fig. 17 a).

Rostrum wide, triangular, axially depressed, downturned, with broken tip. Orbits shallow, elongate, with augenrest consisting of a elongated, depressed area, deeper than orbit, separated from orbit by small ridge (Fig. 17 b); upper orbital margin straight, divided by augenrest ridge, suborbital margin extend anteriorly more than upper orbital margin, orbital angle is $51^{\circ}$ to longitudinal axis, orbits end with blunt outer orbital spine; 
fronto-orbital width, including augenrest, is $88 \%$ of maximum width. Lateral margins from outer orbital node to branchiocardiac groove straight, parallel to longitudinal axis. Cervical groove well defined, lateral third deeply incised; median third curved posteriorly defining posterior side of mesogastric region; at connection point of middle third with lateral third two weakly shallow grooves arise and curve anteriorly, defining lateral margins of mesogastric region. Postcervical groove not defined. Branchiocardiac groove not preserved.

Epigastric region comprised of two moderately prominent ovoid bulbs, posteriorly converging, separated by deep sulcus. Mesogastric region transversely ovate, width about $53 \%$ of maximum width, well defined posteriorly by cervical groove, lateral sides defined by two shallow grooves connected to cervical groove; anterior side weakly defined, reaching epigastric region by anterior process. Metagastric and urogastric region poorly preserved. Protogastric and hepatic regions not differentiated. Epibranchial regions well defined by cervical groove, slightly convex. Cuticle covered with small pits. Abdomen, venter, and appendages not preserved.

Materia 1 examined: One specimen was examined, presented in Appendix. Me a s u re ment s: Measurements in mm presented in Table 6.

D is c u s s i o n: The single specimen was collected from Topalu and has an age within late Oxfordian to early Kimmeridgian. Even though the specimen is poorly preserved, morphological characters such as the pattern of the cervical grove, the shape of the lateral margin, the flatness of the carapace, the way the suborbital margin extends anteriorly 
more than upper orbital margin, and the type of augenrest allowed placement in Tanidromites. This specimen was assigned to Tanidromites $\mathrm{cf}$. T. richardsoni because the oval outline of the mesogastric region differs from the sub-triangular outline of the mesogastric region of $T$. insignis. The deepness of the grooves differs from those of $T$. lingulata; the parallel lateral margins separate this specimen from $T$. lingulata and $T$. etalloni; and the cephalic area of the carapace is less inflated than the cephalic area of $T$. etalloni. 

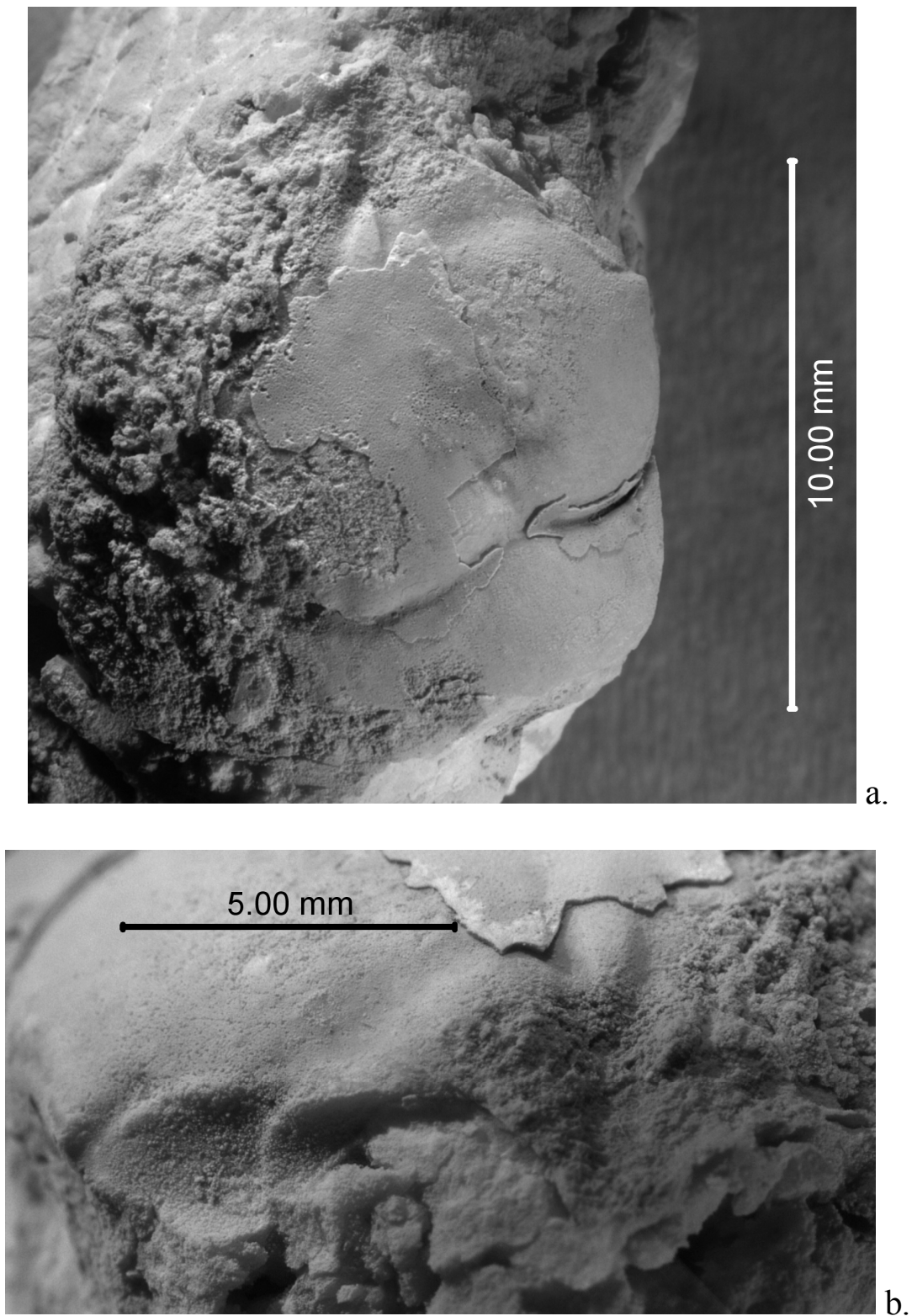

Fig. 17. - Tanidromites cf. T. richardsoni WOODWARD 1907, specimen LPBIIIart-159; a. Dorsal view; b. Anterolateral view showing deeply sulcate, downturned rostrum and orbital area. 
Genus Tanidromitidae n. g.

Type species: Tanidromitidae n. g. n. sp., by monotypy.

Included species: Tanidromitidae n. g. n. sp., herein.

D i a g no s is: As for species.

D is c u s s i o n: This genus has been placed in this family because it has forwarddirected orbits, well developed flanks which are very tall, and a subhepatic region which is similar to those of other genera within Tanidromitidae. However this specimen has a series of characters which make it stand apart as a new genus. The outline of the carapace is more oval than for other species within Tanidromites; the branchiocardiac groove is poorly developed, only on the lateral thirds; all of the regions are poorly defined or not developed; the lateral margins have a deep reentrant from the anterior part of epibranchial region to the mid section of metabranchial region; and the posterior margin is deeply concave.

Tanidromitidae n. g. n. sp.

Fig. 18.

D i a g n o s is : Carapace longitudinally ovate, tall, with steep lateral flanks; lateral margins with deep reentrant; regions poorly defined or not developed; subhepatic regions with flat surface; metabranchial regions with four spines.

De s c r ipt i o n : Carapace ovate, longer than wide, width $85 \%$ of maximum length, anterior third about $43 \%$ of maximum length, slightly vaulted transversely and moderately vaulted longitudinally, point of maximum convexity in middle of metagastric 
region, maximum width of carapace in anterior part of epibranchial regions at about $37 \%$ of total length. Carapace traversed by two grooves, cervical groove well incised, branchiocardiac groove poorly developed only on the lateral thirds. Flanks tall, slightly convex, converging ventrally (Fig. 18 a).

Rostrum not preserved; orbits short, at angle of $67^{\circ}$ the longitudinal axis, suborbital margin appears to extend anteriorly more than upper orbital margin. Fronto-orbital width $68 \%$ of maximum width. Anterolateral margins rounded anteriorly, converging on longitudinal axis. Lateral margins deeply indented posterior to epibranchial region, with remains of a large spine on the anterior side of epibranchial region and remains of up to five small spines on branchial region. Posterolateral margins rounded, posteriorly converging on longitudinal axis. Posterior margin poorly preserved.

Cervical groove well defined; median third weakly curved posteriorly defining posterior side of mesogastric region; it appears that at connection point of middle third with lateral third two weakly shallow grooves arise and curve anteriorly, defining lateral margins of mesogastric region. Postcervical groove not defined. Branchiocardiac groove well developed on lateral third, not developed on median third. Cervical and branchiocardiac grooves approximately parallel with each other.

Epigastric region not differentiated. Mesogastric region transversely ovate, width about $78 \%$ of maximum width, well defined posteriorly by cervical groove, lateral sides defined by two shallow grooves connected to cervical groove; anterior side not differentiated from epigastric region; small notch on posterior side represents separation 
point of insertion of masticator muscle. Metagastric and urogastric regions poorly developed and not differentiated, rectangular, short, transverse to longitudinal axis. Cardiac region poorly developed, pentagonal, apex oriented posteriorly, moderately prominent; wider than long, length $68 \%$ of width. Intestinal region poorly defined, large triangular depressed area, length $17 \%$ of total length of carapace, apex of triangle oriented anteriorly. Protogastric and hepatic regions not differentiated. Subhepatic region poorly defined by ventral extensions of the cervical groove, slightly depressed (Fig. 18 b). Epibranchial regions well defined by cervical and branchiocardiac grooves. Mesobranchial and metabranchial regions not differentiated. Abdomen, venter, and appendages not preserved.

T у р е : LPBIIIart-158 - Holotype.

Measurements: Measurements in mm presented in Table 7.

D i s c u s s i o n: The single specimen was collected from Topalu, and has an age within the late Oxfordian to early Kimmeridgian. The roundness of the anterolateral and posterolateral margins gives this species a distinctive ovate shape of the carapace, and combined with the steepness of the lateral flanks (Fig. $18 \mathrm{c}$ ), this carapace looks like a dome. Also, the two reentrants on the lateral margins makes it to stand apart as a distinct new genus and species. 

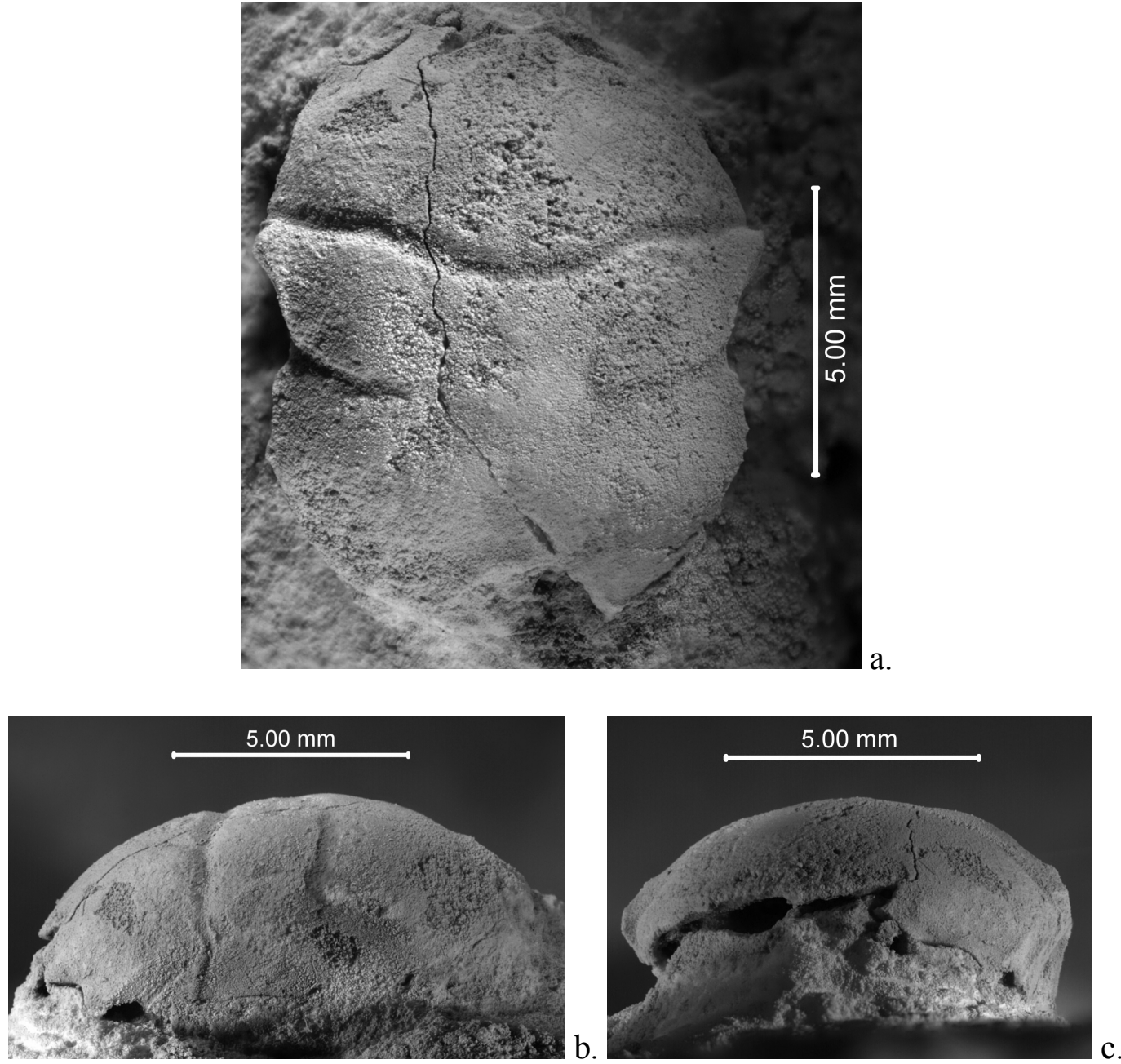

Fig. 18. - Tanidromitidae n. g. n. sp. specimen LPBIIIart-158 Holotype; a. Dorsal view; b. Lateral view; c. Frontal view. 
Family Prosopidae VON MEYER 1860

Genus Laeviprosopon GLAESSNER 1933

Ty p e s p e i e s: Prosopon laeve VON MEYER 1857.

I n c lu d ed s p e c i e s : Laeviprosopon fraasi (MOERICKE 1889), as Prosopon; L. grandicentrum SCHWEITZER \& FELDMANN 2008; L. laeve; L. laculatum SCHWEITZER \& FELDMAnN 2008; L. punctatum (VON MEYER 1857), as Prosopon; L. sublaeve (VON MeYer 1857), as Prosopon, Laeviprosopon n. sp. herein.

D i a g n o s is : "Carapace rectangular, longer than wide, often narrowing slightly anteriorly; regions well-defined by deep grooves; rostrum trifid or broadly convex, projected well beyond orbits; orbits shallow, rimmed, directed forward, located at base of rostrum; augenrest poorly formed to nearly absent; Subhepatic region inflated, sometimes greatly; epigastric, protogastric and hepatic regions separated by transverse grooves into three anteriorly to posteriorly successive regions; cervical groove deep, strongly concave forward; branchiocardiac groove shallower than cervical groove; postcervical groove short, interrupted axially; posterolateral portions of carapace often broken as if less calcified than other portions of carapace.” (SCHWEITZER \& FELDMANN 2008, p. 276)

\section{Laeviprosopon $\mathrm{n} . \mathrm{sp}$.}

Fig. 19.

D i a g n o s is : Carapace rhombohedral, anterolateral margins strongly converging anteriorly; rostrum broad, triangular, depressed; mesogastric region highly inflated; 
hepatic and subhepatic regions inflated and with two large spines; protogastric and hepatic regions well differentiated; cardiac region narrow, long, with three notes.

De s c r ipt i o n : Carapace rhombohedral, longer than wide, width $67 \%$ of maximum length, maximum width at middle of epibranchial region, strongly vaulted transversely and longitudinally, point of maximum convexity in middle of mesogastric region. Carapace traversed by two well incised transverse grooves, metabranchial regions not preserved (Fig. 19 a).

Rostrum short, broad, triangular, spatulate, with broken tip; orbits pointing forward, upper orbital rim with reentrant. Fronto-orbital width $63 \%$ of maximum width. Posterolateral margins not preserved. Posterior margin partially preserved.

Cervical groove well defined, composed of three arched segments; median third curved posteriorly defining posterior side of mesogastric region; at connection point of middle third with lateral third two distinct grooves arise and curve anteriorly, defining lateral margins of mesogastric region. Postcervical groove weakly defined as two short depressed segments, posteriorly converging. Branchiocardiac groove well developed, median third curved posteriorly defining lateral and posterior side of cardiac region, median third not reaching onto posterior margin. Cervical and branchiocardiac grooves are approximately parallel with each other.

Epigastric region, weakly developed, comprised of two moderately prominent ovoid swellings, perpendicular to longitudinal axis, separated by sulcus, anterior part slightly depressed. Mesogastric region ovate, transverse to longitudinal axis, highly 
inflated, bulbous (Fig. 19 b); width about $44 \%$ of maximum width, well defined posteriorly by cervical groove, faint keel separates attaching points for masticator muscles; lateral sides defined by two distinct grooves connected to cervical groove; anterior side weakly defined, reaching epigastric region by anterior process. Metagastric region well developed, rectangular shape, short, wider than mesogastric region, transverse to longitudinal axis. Urogastric region weakly developed, slightly depressed. Cardiac region well developed, long, triangular, posteriorly oriented apex, two inflated nodes on anterior side. Intestinal region poorly developed as small depressed area between metabranchial regions. Hepatic regions well developed, divided in two subregions, with one small spine at the lower part on each subregion. Subhepatic regions well developed, well differentiated, highly inflated (Fig. 19 c), divided into subregions, anterior subregion acts as protective cover for augenrest, posterior subregion with large spine on superior margin. Epibranchial regions well defined, moderately inflated, ovate in shape, posteriorly converging, anterolateral ends poorly preserved. Metabranchial regions not preserved.

Abdomen, venter, and appendages not preserved.

T y p e s : LPBIIIart-161-1 - Holotype; LPBIIIart-161-2 - Paratype Me a sure me n t s: Measurements in mm presented in Table 8. D is c u s s i o n: The specimens were collected from Topalu and have an age within the late Oxfordian to early Kimmeridgian. The rhombohedral outline of the carapace is due to lack of preservation of the posterolateral sides of the carapace, most likely because of 
their weak calcification; a defining character of the superfamily. Careful examination of the specimens and their morphology showed some important differences between this new species and Laeviprosopon laeve such as that the rostrum is short and triangular on the new species compared with the trifid rostrum of L. laeve; the subdivision of hepatic and subhepatic regions of the new species is not present on L. laeve; and the new species presents large spines on the hepatic and subhepatic region and also on the rim of the augenrest, spines that are not present on L. laeve. The mesogastric region of the new species is subrounded compared with L. laeve, which has a subtriangular mesogastric region. Also the anterior process of the new species is not as developed as in L. laeve; and the cardiac region is less inflated and narrow on the new species compared with $L$. laeve. This new species differs from $L$. fraasi because the anterior process of the mesogastric region of L. fraasi it is well developed, longer and wider, completely separating the epigastric regions; cervical groove of Laeviprosopon n. sp. is more arcuate than the cervical groove in L. fraasi which also have a much wider cardiac region than Laeviprosopon n. sp. 

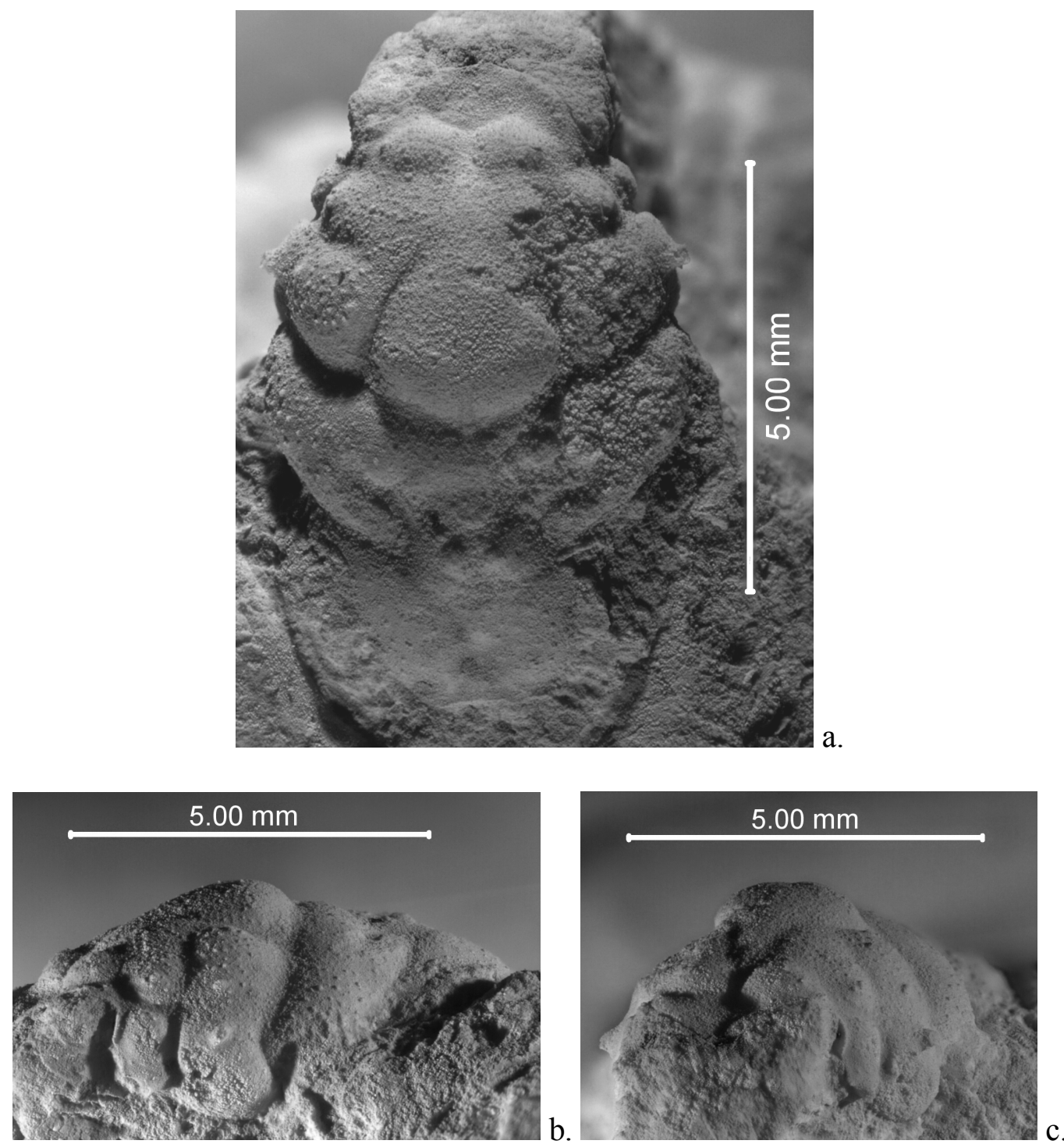

Fig. 19. - Laeviprosopon n. sp. specimen LPBIIIart-161-1 Holotype; a. Dorsal view; b. Lateral view; c. Antero-lateral view. 
Superfamily Glaessneropsidea PATRULIUS 1959

Family Glaessneropsidae PATRULIUS 1959

Genus Verrucarcinus SchweITZER \& FELDMANN 2009

Ty p e spe cies: Prosopon torosum VON MeYer 1857.

In c lu ded spe cie s: Verrucarcinus ordinatus (Collins in Coluins \&

WIERZBOWSKI 1985), as Nodoprosopon; V. torosus; Verrucarcinus n. sp. herein.

D i a g n o s is : "Carapace longer than wide, widest at position of branchial regions, about three-quarters the distance posteriorly on carapace; carapace regions bulbous, ornamented with large granules, especially large on branchial regions. Rostrum projected well in advance of orbits, spatulate, downturned, with triangular axial swelling, flattened on either side of swelling, tip of rostrum with spines, rostral width about half maximum carapace width. Eyestalk appearing to have arisen beneath rostrum. Orbit bounded on inner angle by rostrum; upper orbital margin formed of rectangular intraorbital spine bounded by deep, open fissures; fissures and spine directed anterolaterally; outer-orbital angle formed of spine with long, triangular, forward-directed spine that wraps around laterally into cup-shaped structure; orbit directed forward; fromto-orbital width about 75 $\%$ maximum carapace width. Metagastric region bilobed; cervical and branchiocardiac grooves well developed; postcervical groove absent. Cardiac region small, circular, positioned well anterior of posterior margin." (SCHWEITZER \& FELDMANN 2009, p. 89). 
Verrucarcinus n. sp.

Fig. 20.

D i a g n o s is : Carapace ovate; cervical groove moderately incised, comprised of three arches; posterior side of mesogastric region well rounded; protogastric regions defined only on posterolateral sides; metagastric region not subdivided; ornamentation comprised of low nodes, large spines only on the posterolateral margins.

D e s c r ipt i o n : Carapace ovate, longer than wide, width $79 \%$ maximum length, maximum width at middle of metabranchial regions, strongly vaulted transversely and longitudinally, point of maximum convexity in middle of cardiac region. Carapace traversed by two well incised transverse grooves (Fig. 20 a).

Rostrum not preserved; orbital rim at angle of $67^{\circ}$ to longitudinal axis; sub-orbital spine triangular, upper orbital spine with rectangular shape, both anterolaterally oriented; outer orbital spine triangular, anteriorly oriented. Fronto-orbital width $67 \%$ of maximum width. Anterolateral margins straight, converging anteriorly on longitudinal axis. Lateral margins behind branchiocardiac groove with 5-7 large nodes with small spines on them. Posterolateral margins and posterior margin arcuate; posterior margin has spines and depressed rim.

Cervical groove well defined as three concave forward arches; median arch weakly curved posteriorly defining posterior side of mesogastric region; at connection point of middle third with lateral third two weakly shallow grooves arise and curve anteriorly, defining lateral margins of mesogastric region. Postcervical groove weakly 
defined as two segments, anteriorly converging, connected to branchiocardiac groove, defining anterior side of cardiac region. Branchiocardiac groove well developed, median third curved posteriorly defining lateral and posterior side of cardiac region, terminate perpendicular to posterior rim, completely separates metabranchial regions. Cervical and branchiocardiac grooves are approximately parallel with each other.

Epigastric region poorly preserved, weakly developed, comprised of two moderately prominent subrounded swellings separated by sulcus. Mesogastric region triangular with apex oriented anteriorly, width about $40 \%$ of maximum carapace width, well defined posteriorly by cervical groove, lateral margins defined by two shallow grooves connected to cervical groove; anterior side weakly defined, reaching epigastric region by anterior process, with very poorly developed longitudinal groove. Metagastric region very well developed, bilobate, transversely oriented, defined by cervical groove on the anterior side and posterior side defined by branchiocardiac and postcervical grooves, axially divided by a longitudinal groove. Urogastric region not developed. Cardiac region, short, well developed, pentagonal with concave sides parallel to longitudinal axis, posterior side more inflated than anterior side. Intestinal region poorly developed as a small depression between metabranchial regions. Hepatic regions well developed, circular, anterior side weakly differentiated from epigastric regions. Subhepatic regions well developed, well differentiated, moderately inflated, with spines on anterolateral margin (Fig. 20 b). Epibranchial regions well defined, weakly differentiated from metagastric region, ovate in shape, posteriorly converging, anterior sides moderately 
inflated. Mesobranchial and metabranchial regions not differentiated, well developed, inflated.

Carapace covered by small tubercles, large nodes present only on posterolateral margin. Abdomen, venter, and appendages not preserved.

\section{T y p e : LPBIIIart-160 - Holotype}

Me a s ure ment s: Measurements in mm presented in Table 9.

D is c u s s i o n: The specimen was collected from Topalu and has an age within the late Oxfordian to early Kimmeridgian. This new species has been placed within this genus because the outline of the carapace, the morphology of the orbital areas, and the size and the shape of the cardiac region are similar to those of other species of Verrucarcinus. Compared with Verrucarcinus torosus VON MEYER 1856, the carapace of Verrucarcinus n. sp. is shorter, wider, and flatter than of $V$. torosus which is longer and narrower making him look like an arrow head; cardiac region of Verrucarcinus n. sp. is longer and poorly defined on the anterior part where as $V$. torosus has a well defined cardiac region; intestinal region is longer in Verrucarcinus n. sp.; posterior margin is wider; posterior part of mesogastric region is more rounded; lateral parts of the metagastric regions are weakly differentiated from the epibranchial regions; the third segment of the carapace, from the branchiocardiac groove to posterior margin, is longer or equal with the anterior two segments, where in $V$. torosus the third segment is shorter than the anterior two segments; third segment ornamentation consist of large nodes and small spines only on the lateral sides, anterior segments are ornamented with small nodes. 
When compared with $V$. ordinatus, Verrucarcinus n. sp. has grooves surrounding the mesogastric region and the postcervical groove less incised; the metagastric region is not as divided as in $V$. ordinatus, being almost one single area, and the ornamentation of the metabranchial regions differ because Verrucarcinus $\mathrm{n}$. sp. has small nodes on the branchial regions, and has large spines only on the outline of metabranchial regions, whereas $V$. ordinatus has large nodes covering the entire branchial area and has no spines. 

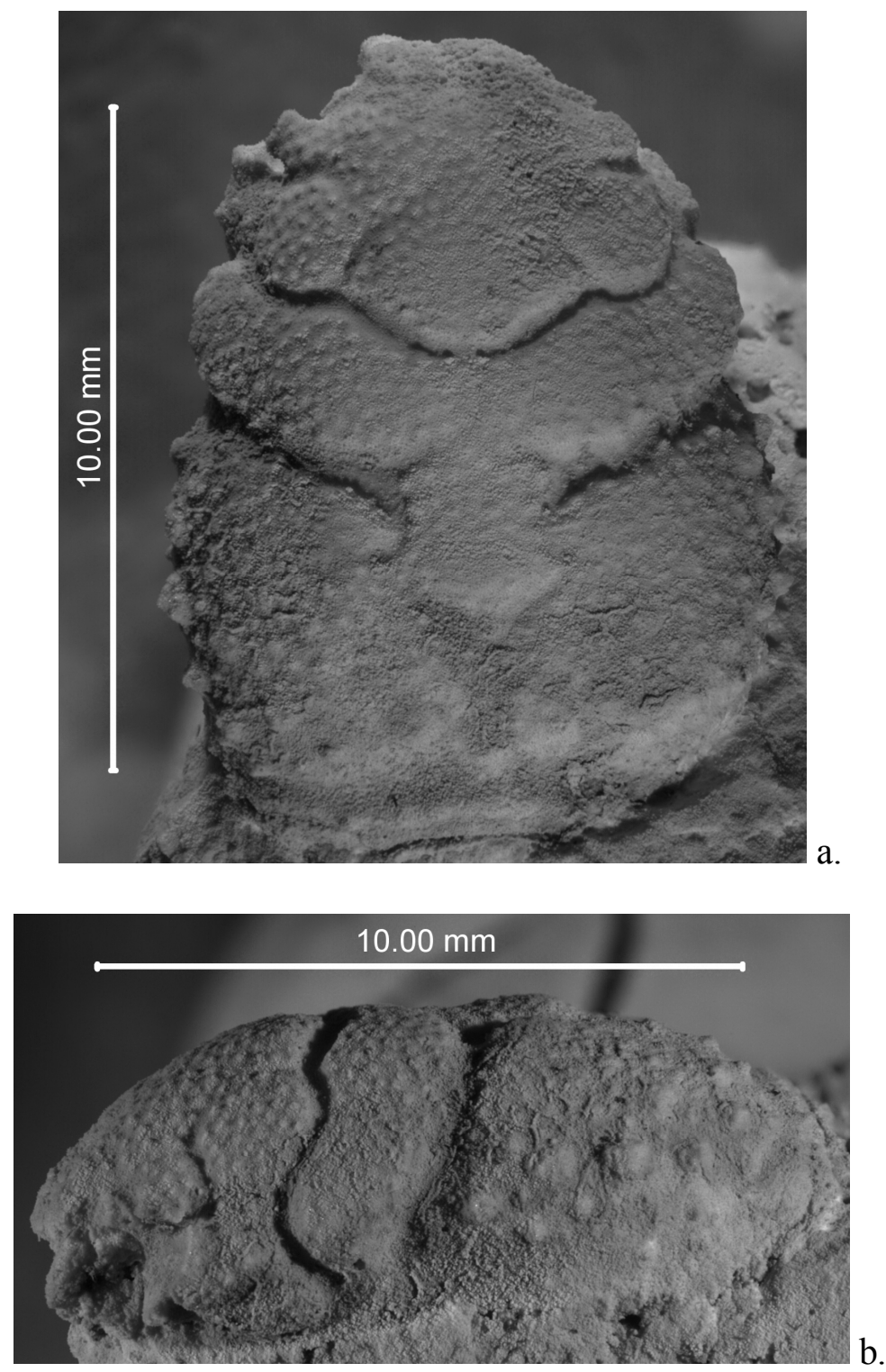

Fig. 20. - Verrucarcinus n. sp. specimen LPBIIIart-160 Holotype; a. Dorsal view; b. Lateral view. 
Family Lecythocaridae SCHWEITZER \& FELDMANN 2009

Genus Lecythocaris VON MEYER 1860

T y p e s p e i e s: Prosopon paradoxum VON MEYER 1858.

In c lu d e d s p e c i e s : Lecythocaris obesa SCHWEITZER \& FELDMAnN 2009; L. paradoxa (VON MEYER 1858); Lecythocaris n. sp. herein.

D i a g n o s is : "Generally small crabs, triangular in outline, with widest part in metabranchial region which is extremely large and bears a prominent node or swelling on anterolateral corner; regions strongly inflated and separated by distinct, deep grooves; grooves not necessarily identifiable as cervical, branchiocardiac, and postcervical. Rostrum broad, spatulate, axially sulcate, and strongly downturned. Orbits circular, rimmed, separated from rostrum by prominent, open notch; with inner suborbital spine. Mesogastric region narrow. Cardiac region very large, extending nearly to posterior border and completely separating metabranchial regions. Hepatic and epibranchial regions developed as globose swellings" (SCHWEITZER \& FELDMANN 2009, p. 94).

Lecythocaris n. sp.

Fig. 21.

D i a g n o s is : Carapace triangular, wider than longer; deep well incised grooves; highly inflated regions; mesogastric region poorly differentiated; large, inflated hepatic regions; small cardiac region; epibranchial region developed as two prominent nodes. De s c r ipt i o n : Carapace triangular, wider than longer, width $105 \%$ maximum length, maximum width metabranchial regions, strongly vaulted transversely and 
longitudinally, point of maximum convexity at protogastric regions. Carapace traversed by deep, incised grooves. All regions inflated, bulbous, well defined (Fig. 21 a).

Rostrum poorly preserved, appears to be broad, spatulate, with rounded downturned tip, axially depressed. Orbits pointing forward, upper orbital rim with ovoid reentrant; Suborbital rim appears to extend forward more than upper rim, same type of reentrant, and one suborbital spine. Fronto-orbital width $54 \%$ of maximum width. Posterior margin deeply concave.

Cervical groove weakly developed, poorly defined, arched. Postcervical groove weakly defined only in axial region as short straight segment perpendicular to mid axis. Branchiocardiac groove poorly defined as two arcuate segments delimiting metabranchial regions, two arcs connect with posterior rim, never with each other. Posterior rim well defined along entire length.

Epigastric region not differentiated from protogastric region, weakly developed as subcircular, flat areas, separated by anterior process of mesogastric region. Mesogastric region triangular, apex anteriorly oriented, poorly defined, slightly inflated, small, $23 \%$ of maximum width; lateral sides defined by two shallow grooves connected to cervical groove; anterior side weakly defined, reaching epigastric region by anterior process, which is well developed. Metagastric region well developed, rectangular, transversely oriented. Urogastric region not differentiated. Cardiac region well developed, highly inflated, almost circular. Intestinal region not differentiated. Protogastric regions well developed, ovate, longitudinally oriented, highly bulbous on posterior side. Hepatic 
regions small, weakly developed, remains of up to two laterally oriented spines.

Subhepatic regions very well developed, well differentiated, highly inflated on the ventral side (Fig. 21 b), remains of two spines. Epibranchial regions weakly defined as two inflated nodes, ovate in shape, converging posteriorly, anterolateral margins poorly preserved. Metabranchial regions very well developed, ovate, converging posteriorly, highly inflated, covered with low nodes.

Abdomen, venter, and appendages not preserved.

T y p e : LPBIIIart-162 - Holotype

Me a surements: Measurements in mm presented in Table 10.

D i s c u s s io $\mathrm{n}$ : The specimen has been collected from Topalu and has an age within the late Oxfordian to early Kimmeridgian. Compared with Lecythocaris obesa SCHWEITZER \& FELDMANN 2009 (NHMW 1990/004/4126 - holotype), the mesogastric region of Lecythocaris n. sp. is slightly longer than the mesogastric region in L. obesa, the surrounding grooves of the mesogastric region of the L. obesa are not as deeply developed as in Lecythocaris n. sp.; the protogastric regions of Lecythocaris n. sp. have smaller swellings on the posterior side than the protogastric regions of L. obesa. Metagastric region of Lecythocaris $\mathrm{n}$. sp. is much shorter than metagastric region of $L$. obesa; the cardiac region of Lecythocaris n. sp. is less swollen; nodose swellings on the posterior part of the metabranchial region are absent, and the rostrum and epigastric regions are not that strongly downturned as for L. obesa. 
Comparison with Lecythocaris paradoxa VON MEYER 1858, (1990/0041/3983), the anterior half of Lecythocaris n. sp. is less inflated; the upper orbital rim reentrant is shorter and the base is circular; the mesobranchial swellings are larger; there is a length difference between the two large spines on the metabranchial region; and the carapace of Lecythocaris $\mathrm{n}$. $\mathrm{sp}$. is overall more flattend. 

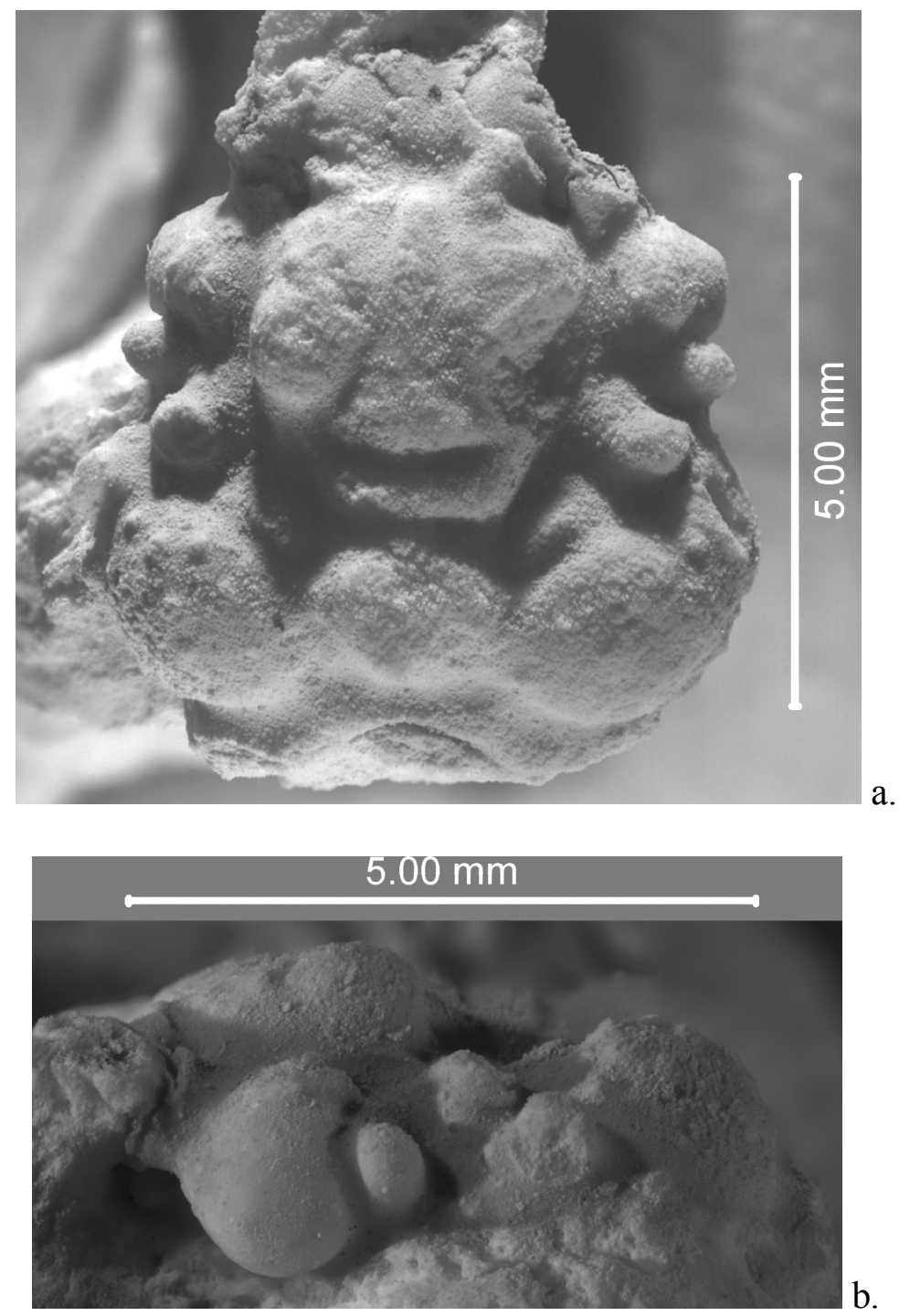

Fig. 21. - Lecythocaris n. sp. specimen LPBIIIart-162 Holotype; a. Dorsal view; b. Lateral view. 
Family Longodromitidae SCHWEITZER \& FELDMANN 2009

Genus Longodromites PATRULIUs 1959

Ty p e s p e i e s: Prosopon angustum REUSS 1858, by original designation.

I n c l u d e d s p e c i e s : Longodromites angustus REUSS 1858; L. bicornutus MUȚIU \& BĂDĂLUȚĂ 1971; L. excisus (VON MEYER 1857), as Prosopon; L. ovalis (MOERICKE 1889), as Prosopon.

D i a g n o s is: "Carapace with parallel of convex lateral margins, longer than wide, widest at position of epibranchial or anterior-most branchial region; regions not-well differentiated; ornamentation granular if present; orbits large, deep, forward directed, with intra-, outer-, and suborbital spines; rostrum projected well beyond orbits, axially sulcate, tip markedly downturned; cervical groove deep; branchiocardiac groove shallow; area between cervical and branchiocardiac grooves narrow; postcervical groove present, variable in development; distinct Subhepatic swelling bounded by cervical and antennar grooves" (SCHWEITZER \& FELDMANN 2009, p. 101).

Longodromites angustus REUSS 1858

Fig. 22.

1858 Pithonoton angustum REUSS, 1858, p. 11.

1858 Prosopon angustum VON MEYER, p. 208.

1859 Pithonoton angustum REUSS, p. 72, pl. 24, fig. 3.

1895 P. [Prosopon] angustum REUSS. - REMEŠ, p. 203, pl. 2, fig. 10.

1889 Prosopon angustum REUSS. - MOERICKE, p.61. 
1897 Prosopon angustum REUSS. - MOERICKE, p. 61.

1929 P. [Pithonoton] angustum VON MEYER. - GLAESSNER, p. 319.

1933 P. [Pithonoton] ? angustum VON MEYER. - GLAESSNER, p. 181.

1959 Longodromites angustus (REUSS 1858). - PATRULIUS, p. 254, fig. 1a.

1966 Longodromites angustus (REUSS 1858). - PATRULIUS, 1966, p. 514, pl. 31, figs. $25,26$.

2009 Longodromites angustus (REUSS 1858). - SCHWEITZER \& FELDMANN, p. 101, figs. 1.6, 7.4-7.7.

Description of materia 1: Carapace ovate, longer than wider, width $72 \%$ maximum length, maximum width in the anterior part of epibranchial region, weakly vaulted transversely and longitudinally, point of maximum convexity in the mesogastric region. Carapace traversed by well incised grooves; strongly dorso-ventrally compressed (Fig 22).

Rostrum poorly preserved, appears to be spatulate, with rounded, sulcate, downturned tip. Orbits rounded, facing forward, shallow, pointing anterolaterally at an angle of $47^{\circ}$ to longitudinal axis. Fronto-orbital width is $84 \%$ of maximum width. Lateral margins straight, parallel to longitudinal axis; posterolateral margins curved, converging posteriorly; posterior margin straight.

Cervical groove well developed, straight, perpendicular to the axis, slightly concave axial to define posterior margin of mesogastric region. Postcervical groove weakly defined, only in axial region, as short, shallow, straight segment perpendicular to 
mid axis. Branchiocardiac groove well defined laterally, poorly defined axially, mid section strongly curved posteriorly to define lateral margins of cardiac region. Posterior rim poorly preserved, weakly defined.

Epigastric region comprised of two slightly prominent circular swellings separated by sulcus. Mesogastric region poorly defined, transversely ovate, width about $37 \%$ of maximum width, connecting to epigastric region by very long anterior process. Metagastric region well developed, long, rectangular shape, transversely oriented. Cardiac region well developed, pentagonal, slightly prominent, with three low nodes. Intestinal region poorly developed. Urogastric region not differentiated. Protogastric region not differentiated. Hepatic regions poorly differentiated, not inflated, with remains of two nodes. Epibranchial regions well defined by cervical and branchiocardiac grooves, slightly inflated, with anterolateral spine, with finger like extension directed at cardiac region. Metabranchial regions well developed, ovate, converging posteriorly. Abdomen, venter, and appendages not preserved. Mat eria 1 exa mine d: Complete list of the five specimens examined is in Appendix.

Mea surements: Measurements in mm presented in Table 11.

D is c u s s i o $\mathrm{n}$ : The specimens were collected from Topalu and have an age estimated at late Oxfordian to early Kimmeridgian. After studying all the morphological characters presented by these specimens, such as: a bifid, downturned rostrum, parallel lateral margins, a flat carapace; and poorly developed regions, the material can be assigned to 
Longodromites angustus. Because these specimens have parallel lateral margins they are different from L. ovalis; and they differ from L. excisus because the cervical groove is straight and the branchiocardiac groove is deeply incised. 


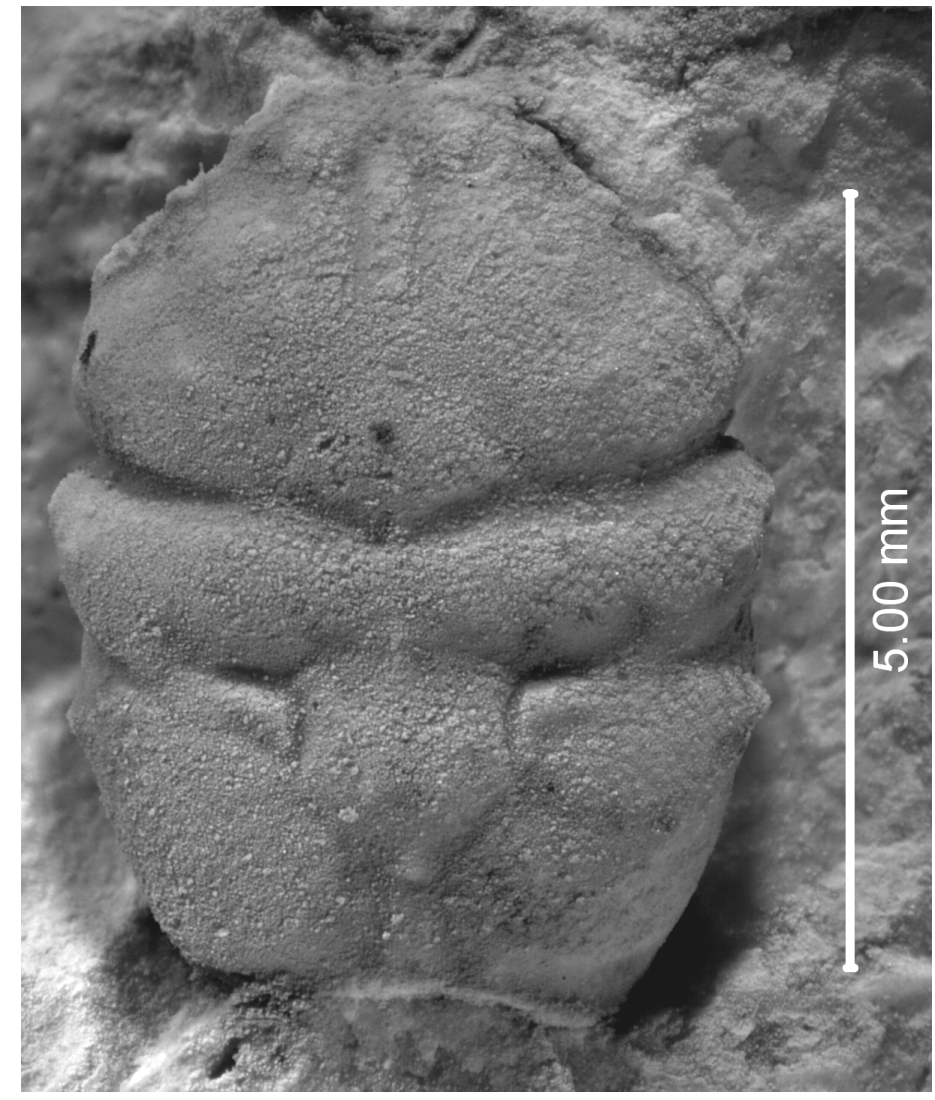

Fig. 22. - Longodromites angustus REUSS 1858, specimen LPBIIIart-163-2; Dorsal view 


\section{PALEOECOLOGY}

During the latest middle Jurassic, central Dobrogea was covered by a warm shallow sea on the northern margin of the Tethys Ocean (Fig. 23.). A carbonate platform depositional environment (Fig. 6.) was established resulting in growth of a multitude of coral patch reefs and sponge reefs (Fig. 9 a, b).

These reefs were composed of multiple types of coral colonies and solitary polyps that were loosely intermixed to form complex frameworks that offered a lot of open spaces. Because of this open framework (DRAGASTAN et al. 1998), the reefs were inhabited by a diverse array of organisms, including bivalves, brachiopods, gastropods, echinoids, crinoids, and decapods. (Fig. 24 a-i). This increased variety of organisms inhabiting the reefs along with the coral polyps provided a great food base for decapods, who are scavengers/predators, resulting in an abundance of decapod taxa within these coral reefs (Fig. 25.). By comparison with sponge reefs from central Dobrogea (Cheia and Gura Dobrogei) (FELDMANN et al. 2006; SchWEITZER et al. 2007), decapods are almost twice as abundant (Fig. 26 a) in the coral reefs. The actual value of this abundance is even higher than ones presented in this paper because specimens assigned to superfamily Galatheoidea SAMOUELLE 1819, have been collected but are not included within this research. The only decapod genera that are common between coral reefs and 


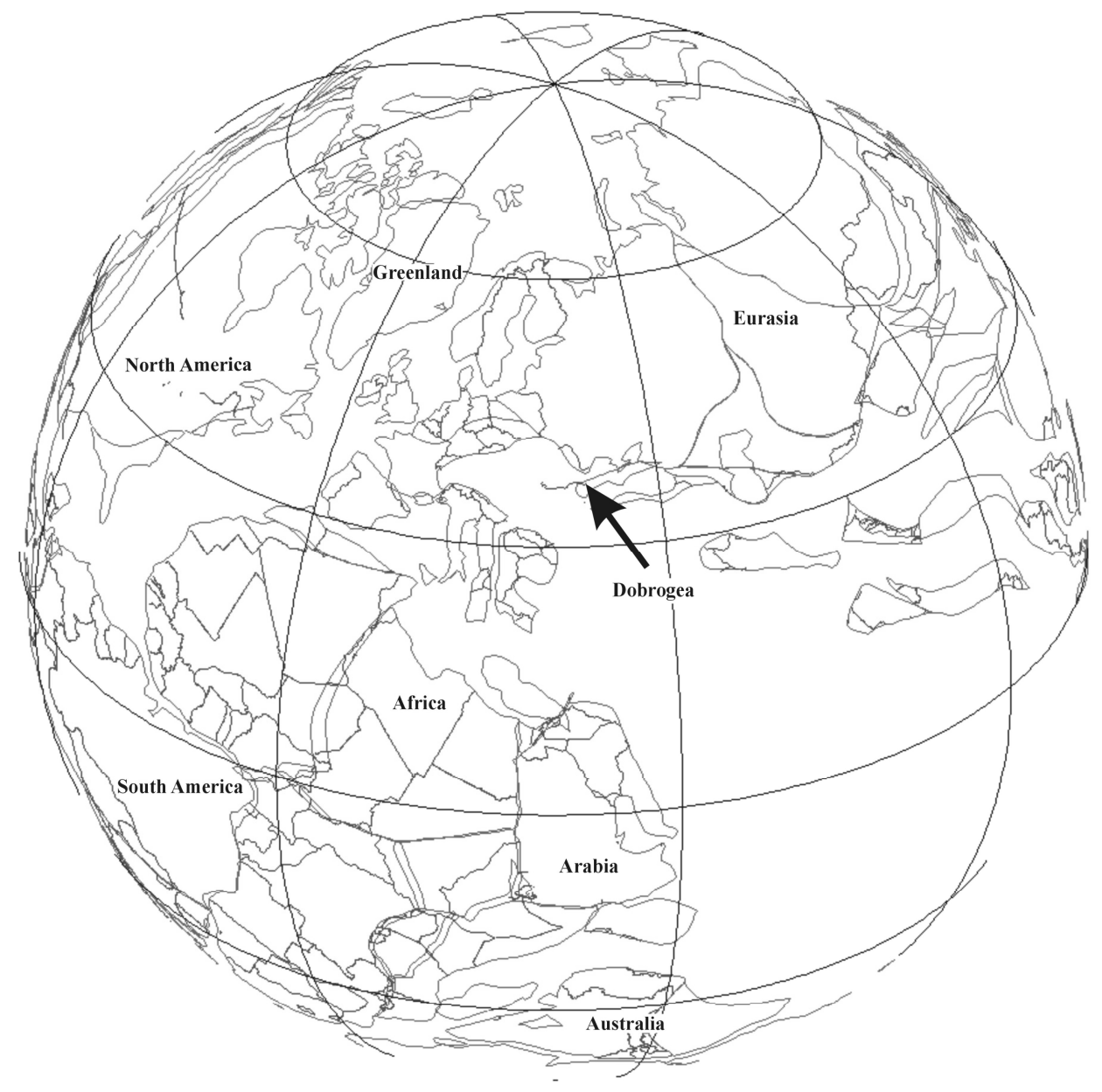

Fig. 23. - Paleogeographic reconstruction at $156 \mathrm{Ma}$ (SCOTESE 2001). 

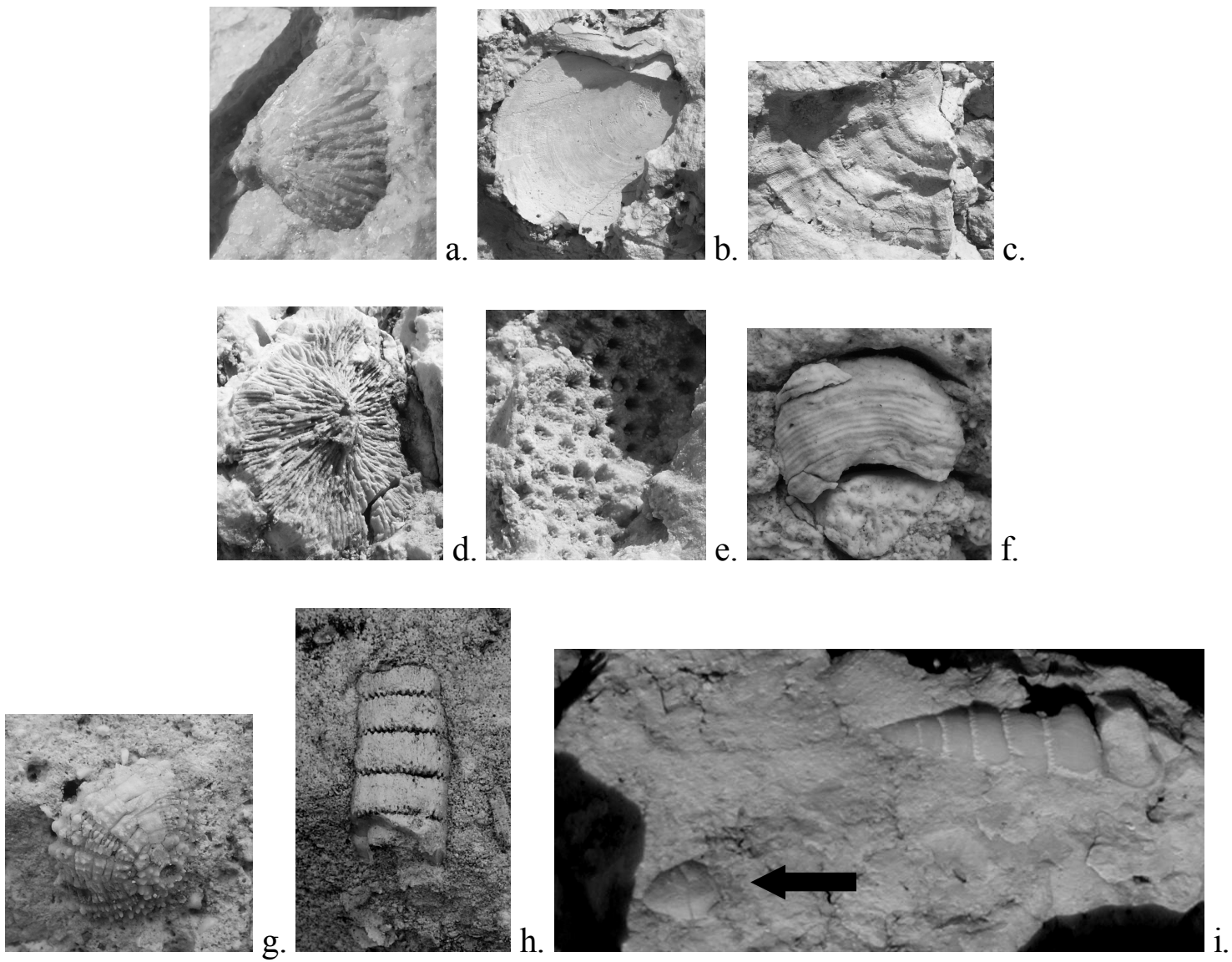

Fig. 24. - Associated fauna from coral reefs; a. - brachiopod; b and c. - bivalves; d. solitary coral; e. - colonial coral; f. - stromatoporoid; g. - echinoid; h. - crinoid stem; i. gastropod next to a decapod (arrow). 


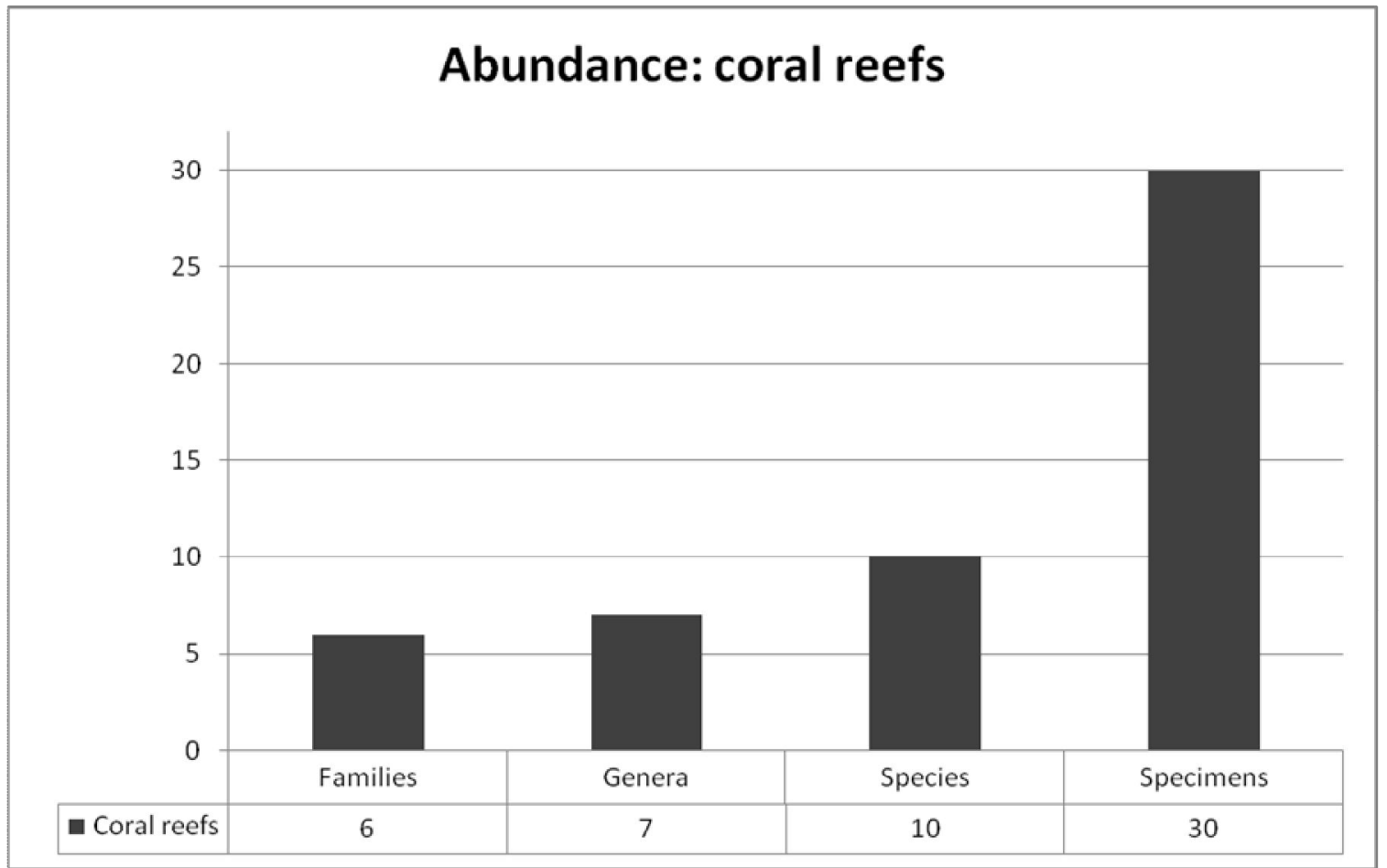

Fig. 25. - Abundance of decapods in coral reef environment from central Dobrogea. 
sponge reefs are the ubiquitous Goniodromites spp. and the more localized Tanidromites sp. (Fig. 26 b). Even though not all the specimens collected were included, the decapod abundance of coral reefs from central Dobrogea is greater than that from coral reefs of Ghergheasa (MUȚIU \& BĂDĂLUȚĂ 1971), just east of the Carpathian Mountains (for locations see Fig. 1). However, it is lower than the decapod abundance from coral reefs within the Carpathian Mountains at Purcăreni (SHIRK 2006), Sinaia, and Moroeni (PATRUlius 1966) (Fig. 27).

It appears that these differences in abundance between coral and sponge reefs from central Dobrogea are due to significant differences in environmental conditions between them such as water depth, energy level, nutrient abundance, sedimentation rate, living space/open framework reef structure, and light conditions (Fig. 28.). From Fig. 28 we can see that coral/siliceous sponge reefs occur in slightly deeper waters, and can likrly cope with some moderate variations, a very low to low sedimentation rate, and environments with almost no fluctuation of nutrient levels. The differences of abundance between coral reefs from central Dobrogea and other localities within România may be due to collecting bias or to the fact that galatheoids decapod have not been included in this research. 

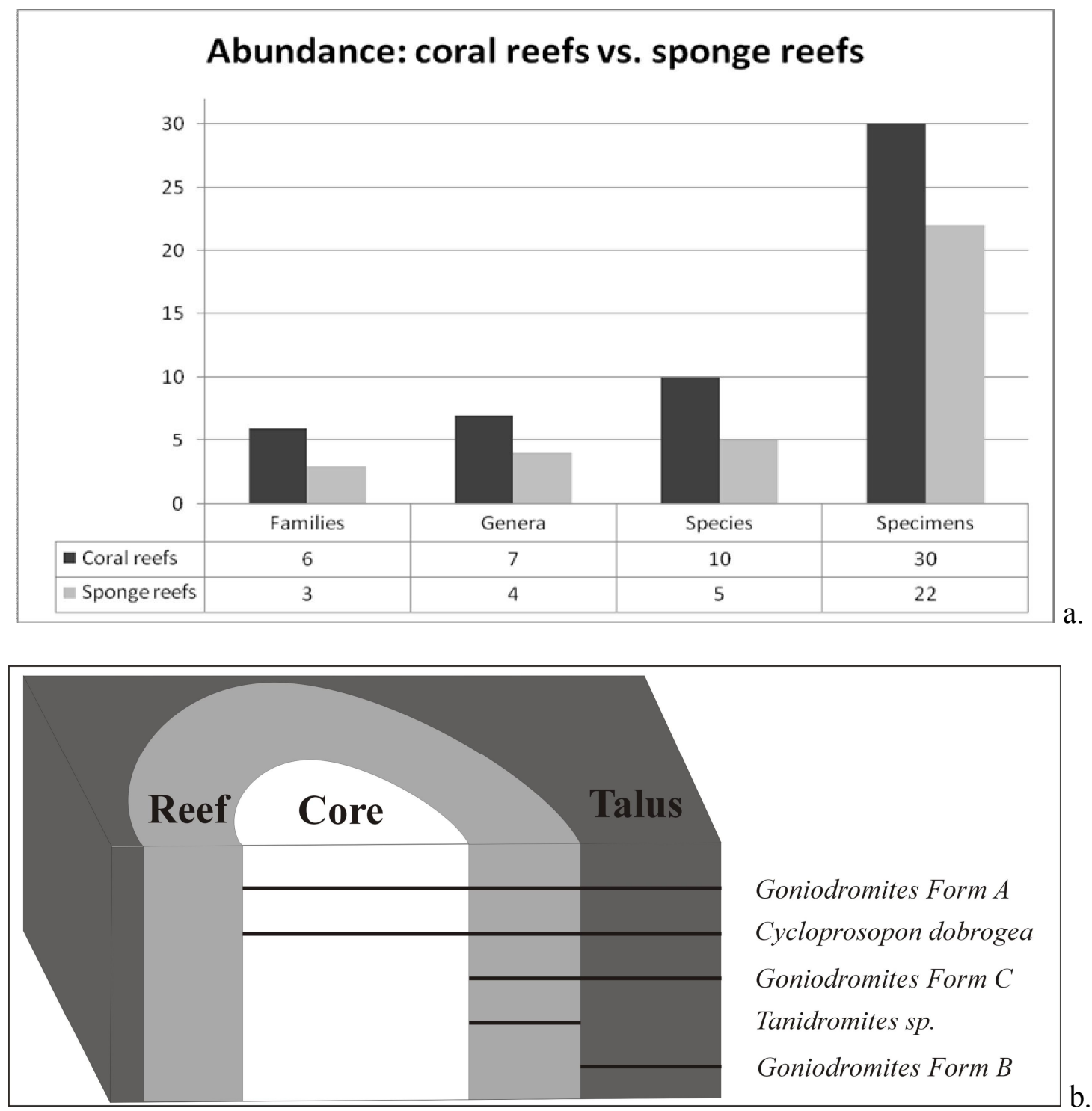

Fig. 26. - Abundance differences between coral and sponge reefs from central Dobrogea;

a. Comparison of decapod abundance between coral reefs and sponge reefs from central Dobrogea; b. Schematic diagram representing the distribution of genera within ringshaped sponge reefs from central Dobrogea (data collected from FELDMANN et al. 2006). 


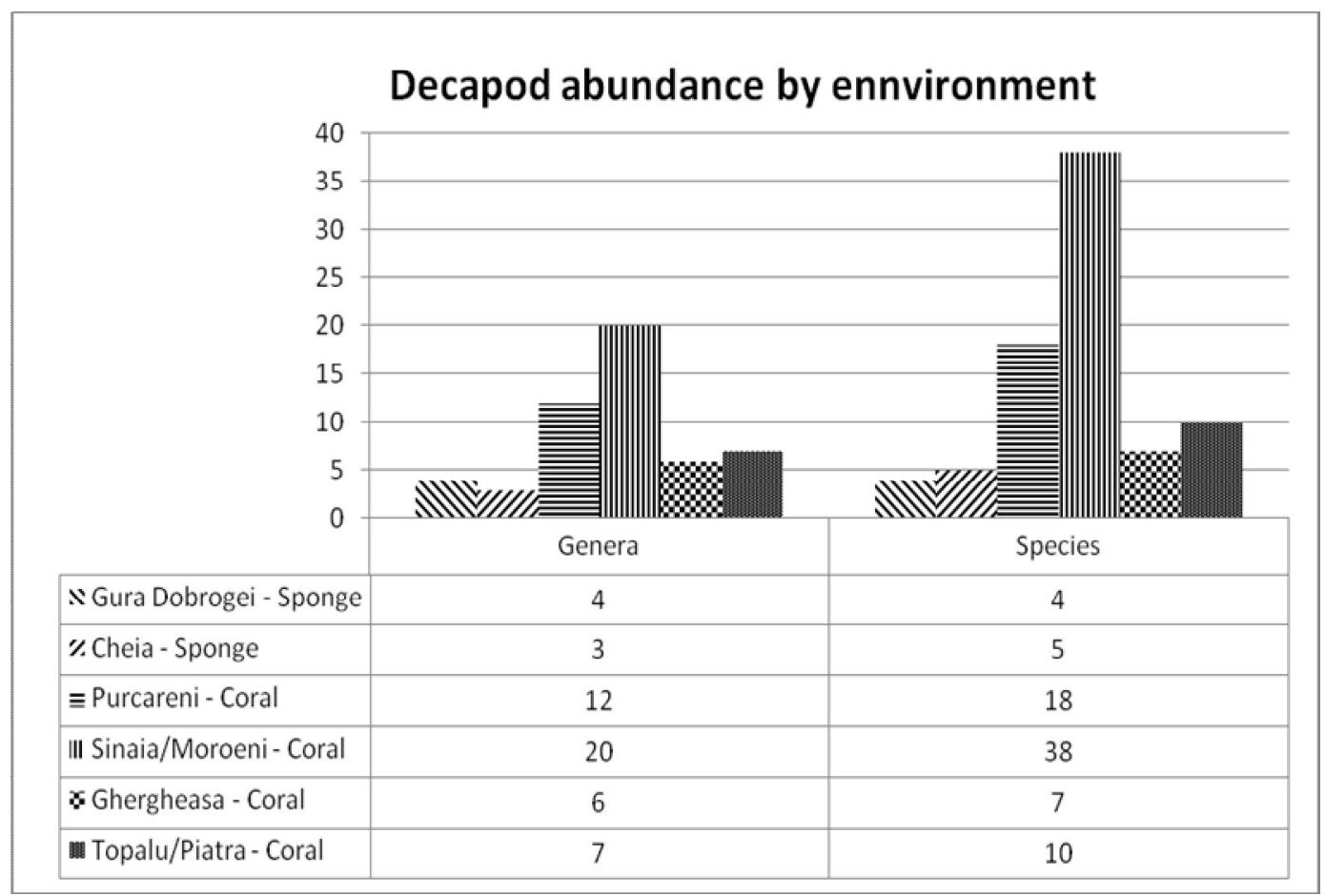

Fig. 27. - Decapod abundance by environment and locality from România. 


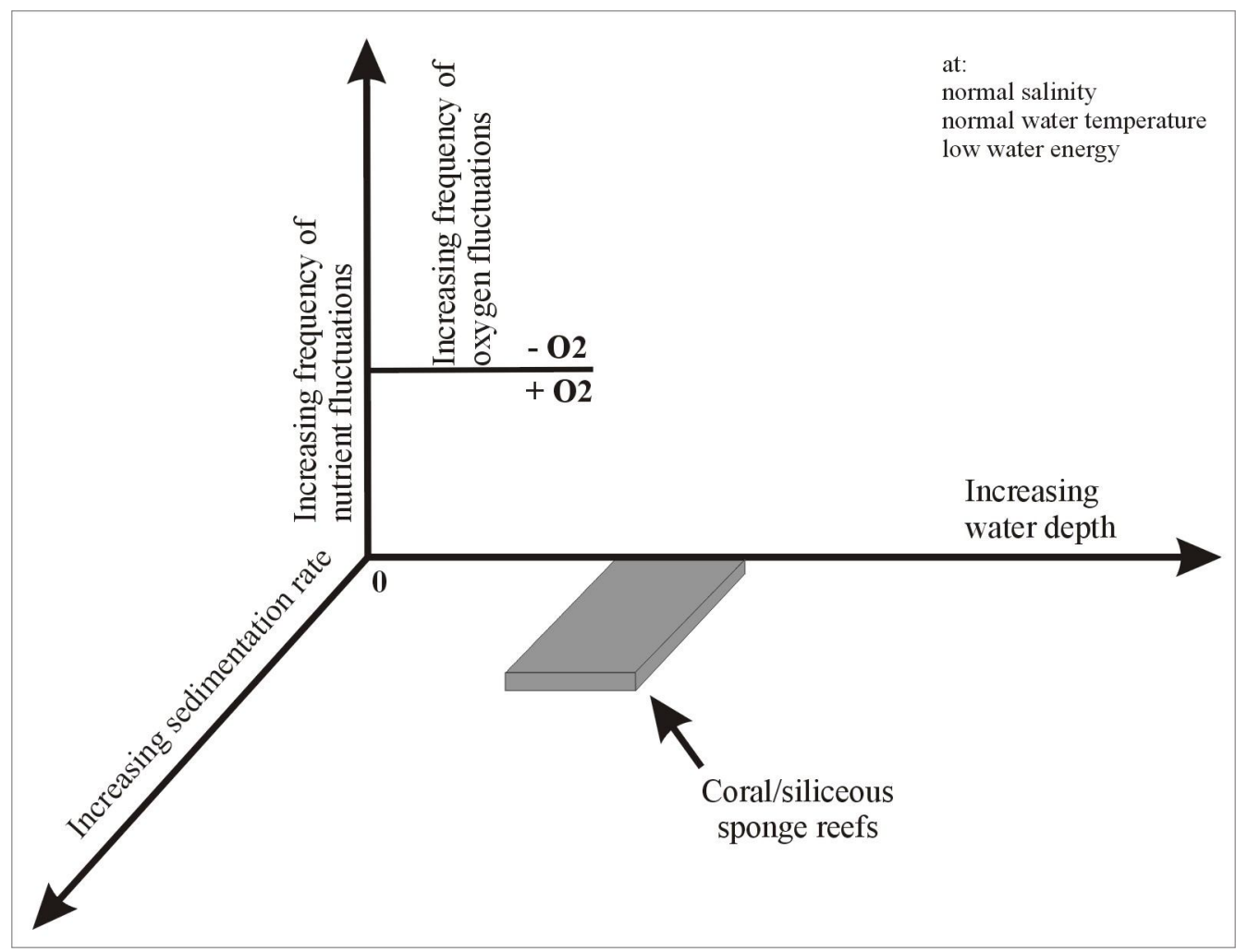

Fig. 28. - Modified version of the triple factor model for Jurassic reefs proposed by LEINFELDER et al. (1996) that shows the depositional settings for coral/siliceous sponge reefs from central Dobrogea. 


\section{CONCLUSIONS}

During the Middle Jurassic, central Dobrogea was a vast carbonate platform formed by a series of coral and sponge reefs. Even though geographic distances are not that great, the environmental settings play a major role in decapod abundance and diversity. Even though galatheoid decapods have not been included in this research project, brachyurans in the coral reef environments are at least twice as diverse as those in the sponge reef environments.

In central Dobrogea there are only two shared genera and no shared species between these two environments. From the two shared genera, one is Goniodromites sp., an omnipresent genus during the Middle Jurassic in Eastern and Central Europe, and the other one is Tanidromites sp., a more environmentally restricted genus, because it was found only in the reef itself compared with Goniodromites sp., which has been found in

all different reef environments. As mentioned before, galatheoid decapods have not been included in this research project, but further investigations are required in order to understand what factors play a major role in decapod distribution and abundance throughout carbonate environments. Galatheoid decapods have never been mentioned in sponge reefs from central Dobrogea, but they have been collected in substantial numbers from coral reefs. 
In future work, looking more in-depth at the local ecological and depositional setting of these fossiliferous localities, Piatra and Topalu, and comparing the results with the available data from sponge reefs localities, such as Gura Dobrogei and Cheia, may prove to be of great value in understanding the delicate balance and relationships between coral and sponge reefs environments. 


\section{REFERENCE}

AlcocK, A. (1899): Materials for a carcinological fauna of India, 5: The Brachyura Primigenia or Dromiacea. - Journal of the Asiatic Society of Bengal, 68(II:3): 123-169.

ANASTASIU, V. (1898): Contribution a l'étude géologique de la Dobrogea (Roumanie). Terraines secondaires. - Thèse, 133pp.; Faculté de Science de Paris.

BĂRBULESCU, A. (1969): Briozoarele neojurasice de la Topalu. - Studii şi cercetări, geologie, geofizică, geografie, (Geologie), Academia României, Bucureşti, 14(1): $225-238$.

BĂRBULESCU, A. (1970): Amoniţii oxfordieni de la Băltăgeşti (Dobrogea centrală). Studii şi cercetări, geologie, geofizică, geografie, (Geologie), Academia României, Bucureşti, 15(1): 121-133.

BĂRBULESCU, A. (1971): Corelarea faciesurilor organogene din Sinclinalul Casimcea cu cele din Sinclinalul Băltăgeşti-Topalu (Dobrogea centrală). - Buletinul Societăţii Ştiinţifice Geologice din România, Bucureşti. 8: 155-177.

BĂRBULESCU, A. (1974): Stratigrafia Jurasicului din Dobrogea centrala. - 173 pp.; Editura Academiei Republicii Socialiste România, Bucureşti. 
BĂRBULESCU, A. (1979): Cephalopodes de l'Oxfordien inférieur en Dobrogea centrale. Studii şi cercetări, geologie, geofizică, geografie, (Geologie), Academia României, Bucureşti, 22(1): 103-110.

BEURLEN, K. (1925): Über Brachyuren- und Anomurenreste des Schwäbischen Jura. Neues Jahrbuch für Mineralogie Beilageband 52(3): 464-532, 2 figs.

BEURLEN, K. (1929): Brachyurenreste aus dem Lias VON Bornholm mit Beiträgen zur Phylogenie und Systematik der Brachyuren Dekapoden. - Paläontologische Zeitschrift, 14: 52-66.

BEURLEN, K. (1932): Brachyurenreste aus dem Lias VON Bornholm mit Beiträgen zur Phylogenie und Systematik der Brachyuren Dekapoden. - Paläontologishe Zeitschrift, 14: 52-66.

Chiriac, M., Bărbulescu, A., Neagu Th., Dragastan, O. (1977): La Dobrogea centrale et du sud pendant le Jurassique et le Crétacée. - Studii şi cercetări, geologie, geofizică, geografie, (Geologie), Academia României, București, 21: 145-153.

Collins, J. S. H., \& WiERZBOwSKI, A. (1985): Crabs from the Oxfordian sponge megafacies of Poland. - Acta Geologica Polonica, 35(1-2): 73-88.

DIETRICH, W. O. (1919): Ueber sogenannte Tabulaten des Jura und der Kreide, insbesondere die gattung Acantharia. - Zentralblatt fuer Mineralogie, Geologie, und Palaeontologie, 2: 208-218. 
Dragastan, O., Neagu, TH., BĂRbulescu, A., \& PANĂ, I. (1998): Jurasicul şi

Cretacicul din Dobrogea Centrală şi de Sud (Paleontologie şi stratigrafie), 249 pp., - Supergraph Tipo, Cluj-Napoca.

DRĂGĂNESCU, A. (1971): Stabilirea etaloanelor microfaciale ale calcarelor neojurasice din Dobrogea centrală ca bază de studiere a forajelor din Platforma Moesica, Sinclinalul Casimcei, Sector V, Sârtorman - Capul Midia. Tema 166, - Arhivele Institutului Geologic, Bucureşti, 79 pp.

DRĂGĂNESCU, A. (1976): Constructional to spongalgal, algal and coralgal facies in the Upper Jurassic Carbonate Formation of Central Dobrogea (the Casimcea Formation). International Colloquium on Carbonate Rocks and Evaporites, România, Guidebook 15: 13-43. - Institutul de Geologie şi Geofizica, Bucureşti.

DRĂGĂNESCU, A., \& BEAUVAIS, L. (1985): Les facies à Scléractiniaires du Jurassique moyen (Formation de Tichileşti) de la Dobrogea Centrale (SE de la Roumanie). Memoriile Institutului de Geologie şi Geofizica Bucureşti, 33: 17-76.

FeldMAnN, R. M., LAZĂR, I., \& SCHWEITZER, C. E. (2006): New crabs (Decapoda: Brachyura: Prosopidae) from Jurassic (Oxfordian) sponge bioherms of Dobrogea, România. - Bulletin of the Mizunami Fossil Museum, 33: 1-20.

Gemmellaro, G. G. (1869): Studi paleontologici sulla fauna del calzare a Terebratula janitor del Nord di Sicilia. - Parte I, pp. 11-18, pls 2-3; Palermo.

Glaessner, M. F. (1929): Crustacea Decapoda. - In: POMPECKJ, J.F. (Eds.): Fossilium Catalogus: Animalia, pars 41: 1-464; Berlin (W. Junk). 
GALESSNER, M. F. (1933): Die Krabben der Juraformation. - Zentralblatt für Mineralogie, Geologie und Paläontologie, Abtheilung B, 1933: 178-191.

Glaessner, M. F. (1969): Decapoda. - In: MoORE, R.C. (Eds.): Treatise on Invertebrate Paleontology, Pt. R4(2): R400-R533, R626-628; Boulder and Lawrence (Geological Society of America and University of Kansas Press).

GolonkA, J. (2002): Plate-tectonic maps of the Phanerozoic. In: Phanerozoic reef patterns - SEPM Special publication 72: 21-75.

Holthuis, L. B. (1974): The lobsters of the superfamily Nephropidea of the Atlantic Ocean (Crustacea: Decapoda). - Bulletin of Marine Science, 24(4): 723-884.

Hudson, R. G. S. (1954): Jurassic Stromatoporoids from Southern Arabia. Notes et Mémoires. Moyen-Orient, 5, Paris: Museum National d'Histoire Naturelle, 5: 207221.

IONESI, L. (1994): Geologia unitaţilor de platformă şi a Orogenului Nord Dobrogean, 280 pp, Editura tehnică, Bucureşti.

LATREILLE, P. A. (1802-1803): Histoire naturelle, générale et particulière, des crustacés et des insectes. Vol. 3. 468pp. Dufart, Paris.

Leinfelder, R. R., Krautter, M., LAternser, R., Nose, M., Schmid, D. U., Schweigert,G., Werner, W., Keupp, H., Brugger, H., Herrnann, R., Rehfeld-Kiefer, U., Schroeder, J. H., Reinhold, C., Koch, R., Zeiss, A., Schweizer, V., Christmann, H., Menges, G., \& Luterbacher, H. (1994): The Origin of Jurassic Reefs: Current Research Developments and Results. - Facies, 31: 1-56. 
Leinfelder, R. R., Werner, W., Nose, M., Schmid, D. U., Krauter, M., LATERnSer, R., TAKSCS, M., \& HARTMANN, D. (1996): Paleoecology, growth parameters and dynamics of coral, sponge, and microbolite reefs from the late Jurassic, p. 227248. In: Reitner, J., NeuweILER, F., \& GunKEL, F. (eds.) Global and regional controls on biogenic sedimentation. I. Reef evolution, Sb2. Research reports. Gottinger Arbeiten zur Geologie und Palaeontologie. Gottingen

LÖRENTHEY, E., \& BEURLEN, K. (1929): Die fossilen Decapoden der Länder der Ungarischen Krone. - Geologica Hungarica, Serie Paleontologica, Fasciculus 3, 421 pp., 12 tabs., 16 pls.

vON MeYeR, H. (1840): Neue Gattungen fossiler Krebse aus Gebilden vom bunten Sandsteine bis in die Kreide. 1-23; Stuttgart (E. Schweizerbart).

vON MEYER, H. (1857): Briefliche Mittheilungen. Jahrbuch für Mineralogie, Geologie, und Paläontologie, p. 556.

VON MEYER, H. (1858): Briefliche Mittheilungen. - Jahrbuch für Mineralogie, Geologie, und Paläontologie, p. 59-62

VON MeYer, H. (1860): Die Prosopiden oder die Familie der Maskenkrebse. Paleontographica, 7: 183-222.

MiLNE-EDWARDS, A. (1865): Note sur deux nouveaux crustacés fossiles du terrain néocomien du Département de L’Yonne. - Bulletin de la Société des Sciences Historiques et Naturelles de l'Yonne, 19: 341-347.

MoericKe, W. (1889): Die Crustaceen der Stramberger Schichten. - Palaeontographica, supplement II, Sechste Abtheilung: 43-72, pl. 6. 
Moericke, W. (1897): Die Crustaceen der Stramberger Schichten. Palaeontographica, Supplement II, Sechste Abtheilung: 43-72, pl. 6.

Morris, S. G. (1980): Catalogue of the type and Figured specimens of fossil Crustacea (excl. Ostracoda), Chelicerata, Myriapoda and Pycnogonida in the British Museum (Natural History). - Trustees of the British Museum (Natural History), 53 pp., 3 pls.

Mutihac, V., Stratulat, I. M., \& FEChEt, I. M. (2004): Geologia României, 166 pp. Editura Didactică şi Pedagogică, Bucureşti.

MuȚiU, R., \& BĂDĂLUȚĂ, A. (1971): La présence des décapodes anomures et dromiacés dans les calcaires tithoniques de Plate-Forme Moësienne. -Annales Instituti Geologici Publici Hungarici, 54(2): 245-525, pl. 1.

Müller, P., KROBICKI, M., \& G. WeHNER. (2000): Jurassic and Cretaceous primitive crabs of the family Prosopidae (Decapoda: Brachyura) - their taxonomy, ecology and biogeography. - Annales Societatis Geologorum Poloniae, 70: 49-79.

PATRUliUs, D. (1959): Contributions à la systématique des décapodes néojurassiques. Revue de Géologie et Géographie, 3(2): 249-257.

PATRUlius, D. (1966): Les décapodes du Tithonique inférieur de Wożniki (Carpates Polonaises Occidentales). - Annales de la Société Géologique de Pologne, 36: 495-517, pls. $30,31$.

PAtrulius, D., \& Orghidan, T. (1964): Contribuţii la studiul faunei neojurasice din valea Casimcea (Dobrogea Centrală). - Institutul Speologic "Emil Racoviţă”, 3: 229-292. 
QuenstedT, F. A. (1856-1857): Der Jura. - 842 pp., 100 pls; Tübingen (Verlag der H. Lauppschen Buchhandlung).

REMEŠ, M. (1895): Beiträge zur Kenntnis der Crustaceen der Stramberger Schichten. Bulletin International de l'Académie des Sciences de Bohème (Prague), 2: 200204, pls. 1-3.

REuSS, A. E. (1858) [imprint 1857]: Über kurzschwänzige Krebse im Jurakalke Mährens. - Stizungsberichte der Kaiserlichen Akademie der Wissenchaften. MatematischNaturweissenschaftliche Classe, 31: 5-13.

REUSS, A. E. (1859): Zur Kenntnis fossiler Krabben. - Academie der Wissenschaft Wien, Denkschrift 17: 1-90.

RoniEWICZ, E. (1976): Les Scléractiniaires du Jurassique supérieur de la Dobrogea centrale, Roumanie. - Paleontologica Polonica, 34, 121pp.

SAmouelle, G. (1819): The Entomologist's Useful Compendium, or an introduction to the knowledge of British insects, 496 pp. Thomas Boys, London.

SĂNDUlESCU, M. (1984): Geotectonica României, 166pp. - Editura Tehnică, Bucureşti. Schweitzer, C. E., \& Feldmann, R. M. (2008) [imprint 2007]: A new classification for some Jurassic Brachyura (Crustacea: Decapoda: Brachyura: Homolodromioidea): families Goniodromitidae BEURLEN 1932 and Tanidromitidae new family. Senckenbergiana Lethaea, 87(2): 119-156.

Schweitzer, C. E. \& FELdMANN, R. M. (2008): Revision of the genus Laeviprosopon GlAESSNER, 1933 (Decapoda: Brachiura: Homolodromioidea: Prosopidae) 
including two new species. - Neues Jahrbuch fur Geologie und Palaontologie Abhandlungen, 250(3): 273-285.

Schweitzer, C. E., \& Feldmann, R. M. (2009): Revision of the Prosopinae sensu GLAESSNER 1969 (Crustacea: Decapoda: Brachiura) including four new families, four new genera, and five new species. - Annalen des Naturhistorischen Museums in Wien, 110A: 55-121.

Schweitzer, C. E., Feldmann, R. M., \& Lazăr, I. (2007). Decapods from Jurassic (Oxfordian) sponge megafacies of Dobrogea, România and reconsideration of Nodoprosopon BEURLEN 1928. - Neues Jahrbuch für Geologie und Paläontologie, Abhandlungen, 244: 99-113.

Scotese, C. R. (2001): Atlas of Earth History, Volume 1, PALEOMAP Project, Arlington, Texas, $52 \mathrm{pp}$.

SHIRK, A. M. (2006): A novel assemblage of decapod crustacea, from a tithonian coral reef olistolith, Purcăreni, România: systematical arrangement and biogeographical perspective. - Unpublished Master Thesis, Kent State University, Kent, Ohio, 178 pp.

SIMIONESCU, I. (1907): Studii geologice şi paleontologice din Dobrogea. I Fauna cefalopodelor jurasice de la Hârsova, 97 pp. - Academia României, Publicaţii în Fondul V. Adamachi, 21. Bucureşti.

SIMIONESCU, I. (1910): Studii geologice şi paleontologice din Dobrogea. II Lamellibranchiatele, gastropodele, brachiopodele şi echinoidele din păturile 
jurasice de la Hârşova (Dobrogea). - Academia României, Publicaţii în Fondul V. Adamachi, 25: 335-463.

SteInMAnN, G. (1903): Nachtrage zur Fauna vON Stramberg. II. Milleporidium, eine Hydrocoralline aus dem Tithon VON Stramberg. - Beiträge zur Paläontogie und Geologie Osterreich-Ungarns und des Orients, 15(1): 1-8, Wien und Leiptzig. VAN STRAELEN V. (1924) [imprint 1925]: Contribution à l'étude des crustacés décapodes de la période jurassique. - Mémoires d'Academie Royale de Belgique, Cl. Sci., collected in number B, series 2, 7: 1-462.

VAN StRAelen V. (1940): Crustacés Décapodes nouveaux du Crétacique de la Navarre. - Musée Royal d'Historie Naturelle de Belgique, 16(4): 1-5.

TurnseK, D., \& BĂRBulescu, A. (1969): Upper Jurassic Hydrozoa in Central Dobrogea (România). - Geologija, 12: 73-84.

WeHNER, G. (1988): Über die Prosoponiden (Crustacea, Decapoda) des Jura. 154pp., 8pls., 1 insert; - Dissertation zur Erlangung des Doktorgrades der Fakultät für Geowissenschaften der Ludwig-Maximilians-Universität zu München.

Withers, T. H. (1951): Some Jurassic and Cretaceous crabs (Prosoponidae). - Bulletin of the British Museum (Natural History), Geology, 1(6): 171-186, pls. 15-17.

WoOdward, H. (1907): On a new brachyourous Crustacean from the 'Clypeus-Grit' (Inf. Oolite) of the Cottswold Hills. - Geological Magazine, new series, 4: 79-81, pl. 1.

Wright, C. W. \& Collins, J. S. H. (1972): British Cretaceous Crabs. Palaeontographical Society Monographs, 126(533): 1-113. 
YABE, H., \& SugIYAMA, T. (1931): On some spongiomorphoid corals from the Jurassic of Japan. - Scientific Reports 2A, 14: 103-105, Tohoku Imperial University, Tokyo and Sendai. 


\section{APPENDIX}

Tables with complete measurements in $\mathrm{mm}$ for the specimens described.

Table 1. - Measurements in mm for Goniodromites polyodon REUSS 1858.

\begin{tabular}{|c|c|c|c|c|c|c|c|c|c|c|c|c|c|}
\hline Specimen & L & W & MWD & FW & FOW & MGRD & MGRW & CGD & OOSD & CRL & CRD & OA & LA \\
\hline LPBIIIart-165-1 & & 9.69 & 4.53 & & & 4.53 & 4.05 & 3.69 & 0.80 & 2.24 & 7.83 & 43 & 17 \\
\hline LPBIIIart-165-2 & & 11.40 & 5.34 & & & 6.90 & 4.27 & 5.36 & 1.87 & 1.91 & 10.34 & 53 & 21 \\
\hline LPBIIIart-165-3 & 13.64 & 12.17 & & 10.89 & & 6.26 & 4.89 & 4.98 & & 4.02 & 11.33 & \\
\hline LPBIIIart-165-4 & & 4.19 & & & & & 1.66 & & 0.52 & 0.82 & & \\
\hline LPBIIIart-165-5 & & 10.02 & & & & & 4.74 & & 1.27 & & & & \\
\hline LPBIIIart-165-6 & & 3.49 & & & 3.29 & & 1.44 & & 0.91 & 2.13 & & & \\
\hline LPBIIIart-165-7 & 15.24 & 13.42 & 6.34 & 6.85 & 12.02 & 7.44 & 5.58 & 5.46 & 1.70 & 2.97 & 12.48 & 52 & 18 \\
\hline LPBIIIart-165-8 & & & & & & & 5.00 & & 1.35 & 2.89 & & \\
\hline LPBIIIart-165-9 & & & & & & & 4.65 & & & & & & \\
\hline
\end{tabular}


Table 1.(cont.) - Measurements in mm for Goniodromites polyodon REUSS 1858.

\begin{tabular}{|c|c|c|c|c|c|c|c|c|c|c|c|c|c|}
\hline LPBIIIart-165-10 & & 12.63 & 6.80 & & 10.84 & 6.80 & 4.61 & 5.16 & 1.94 & 2.30 & 11.58 & 51 & 19 \\
\hline LPBIIIart-165-11 & & 10.84 & & & 9.69 & & 4.48 & & 1.48 & & & 55 & 21 \\
\hline LPBIIIart-165-12 & & 9.78 & 5.42 & & 8.75 & 5.42 & 3.67 & 3.86 & 1.22 & 2.00 & 8.94 & 48 & 17 \\
\hline LPBIIIart-165-13 & 14.49 & 13.18 & 7.33 & 7.40 & 12.01 & 7.33 & 5.22 & 5.66 & 1.96 & 2.86 & 12.28 & 54 & 18 \\
\hline LPBIIIart-165-14 & 11.09 & 9.79 & 5.35 & 4.82 & 8.74 & 5.35 & 3.84 & 4.40 & 1.44 & 1.70 & 8.76 & 45 & 21 \\
\hline LPBIIIart-165-15 & & 10.48 & & & 9.53 & & & & 1.47 & & & 47 & 12 \\
\hline LPBIIIart-165-16 & 6.50 & 5.93 & 2.82 & 3.10 & 5.26 & 3.35 & 2.37 & 2.70 & 0.89 & 1.02 & 5.25 & 43 & 16 \\
\hline LPBIIIart-165-17 & 16.30 & 15.73 & 4.87 & 7.16 & & 7.38 & 5.90 & 5.94 & 2.19 & 3.09 & 12.76 & 54 & 17 \\
\hline LPBIIIart-165-18 & & 10.18 & 5.86 & 5.84 & & 5.86 & 3.92 & 4.52 & 1.40 & & & 52 & \\
\hline LPBIIIart-165-19 & & 8.83 & 3.47 & 5.05 & 7.92 & 5.27 & 3.67 & 3.89 & 0.67 & & & 56 & \\
\hline LPBIIlart-165-20 & & 8.70 & & & & & 4.23 & & 1.23 & 1.63 & & 41 & 23 \\
\hline
\end{tabular}


Table 2. - Measurements in mm for Goniodromites cf. G. bidentatus REUSS 1858.

\begin{tabular}{|c|c|c|c|c|c|c|c|c|c|c|c|c|c|}
\hline Specimen & L & W & MWD & FW & FOW & MGRD & MGRW & CGD & OOSD & CRL & CRD & OA & LA \\
\hline LPBIllart-166 & & 8.68 & & & 8.02 & & 3.50 & & 1.00 & & & 51 & \\
\hline
\end{tabular}


Table 3. - Measurements in mm for Goniodromites n. sp. FRANȚESCU, 2009.

\begin{tabular}{|c|c|c|c|c|c|c|c|c|c|c|c|c|c|}
\hline Specimen & L & W & MWD & FW & FOW & MGRD & MGRW & CGD & OOSD & CRL & CRD & OA & LA \\
\hline LPBIIlart-164-1 & 19.05 & 17.36 & 9.85 & 9.16 & 15.26 & 9.85 & 6.71 & 7.02 & 2.49 & & & 53 & 27 \\
\hline LPBIIlart-164-5 & & 6.31 & 2.14 & 3.71 & 5.84 & 3.78 & 2.48 & 2.95 & 0.79 & 0.93 & 5.41 & 50 & \\
\hline LPBIIlart-164-6 & & 13.38 & 5.06 & 6.95 & 12.52 & 7.95 & 4.76 & 5.82 & 2.17 & 3.06 & 13.00 & 48 & 15 \\
\hline
\end{tabular}


Table 4. - Measurements in mm for Goniodromites sp. REUSS 1859.

\begin{tabular}{|c|c|c|c|c|c|c|c|c|c|c|c|c|c|}
\hline Specimen & L & W & MWD & FW & FOW & MGRD & MGRW & CGD & OOSD & CRL & CRD & OA & LA \\
\hline LPBIIlart-168-1 & & 9.80 & & & 9.16 & & 3.68 & 4.30 & 0.70 & & & \\
\hline LPBIIlart-168-2 & & 10.23 & & & & & 3.92 & & & 2.73 & & \\
\hline LPBIIlart-168-3 & & & & & & & & & & 2.93 & & \\
\hline LPBIIlart-168-4 & & & & & & & 5.09 & & & & & \\
\hline LPBIIlart-168-5 & & & & & & & & & & & & \\
\hline LPBIIlart-168-6 & & & & & & & 3.36 & & & 1.27 & & \\
\hline LPBIIlart-168-7 & & & & & & & 4.64 & & & & & \\
\hline LPBIIlart-168-8 & & & & & & & 4.25 & & 1.12 & & & \\
\hline LPBIIlart-168-9 & & & & & & & 4.54 & & & & & \\
\hline LPBIIlart-168-10 & & & & & & & 4.03 & & 2.09 & & & \\
\hline LPBIIlart-168-11 & & & & & & & 5.69 & & & & \\
\hline
\end{tabular}


Table 4. (cont.) - Measurements in mm for Goniodromites sp. REUSS 1859.

\begin{tabular}{|c|l|l|l|l|l|l|l|l|l|l|l|l|}
\hline LPBIIlart-168-12 & & & & & & & 3.96 & & & & & \\
\hline LPBIIlart-168-13 & & & & & & & 5.31 & & & & & \\
\hline LPBIIlart-168-14 & & & & & & & & & & & & \\
\hline LPBIIlart-168-15 & & & & & & & & & & & & \\
\hline LPBIIlart-168-16 & & & & & & & & & & & \\
\hline LPBIIlart-168-17 & & & & & & & 5.12 & & & & & \\
\hline LPBIIlart-168-18 & & & & & & & & & & & & \\
\hline
\end{tabular}


Table 5. - Measurements in mm for Eodromites grandis VON MEYER 1857.

\begin{tabular}{|c|c|c|c|c|c|c|c|c|c|c|c|c|c|}
\hline Specimen & L & W & MWD & FW & FOW & MGRD & MGRW & CGD & OOSD & CRL & CRD & OA & LA \\
\hline LPBIllart-167 & & 17.05 & & & & & & & & 3.32 & & 56 & 16 \\
\hline
\end{tabular}


Table 6. - Measurements in mm for Tanidromites cf. T. richardsoni WoODWARD, 1907.

\begin{tabular}{|c|c|c|c|c|c|c|c|c|c|c|c|c|c|}
\hline Specimen & L & W & MWD & FW & FOW & MGRD & MGRW & CGD & OOSD & CRL & CRD & OA & LA \\
\hline LPBIllart-159 & & 18.00 & 14.15 & & 15.88 & 15.78 & 9.51 & & & & & 51 & \\
\hline
\end{tabular}


Table 7. - Measurements in mm for Tanidromitidae n. g. n. sp. FRANȚESCU, 2009.

\begin{tabular}{|c|c|c|c|c|c|c|c|c|c|c|c|c|c|}
\hline Specimen & L & W & MWD & FW & FOW & MGRD & MGRW & CGD & OOSD & CRL & CRD & OA & LA \\
\hline LPBIllart-158 & 10.93 & 9.25 & 4.03 & & 6.29 & 4.75 & 7.20 & 3.69 & & & & 67 & \\
\hline
\end{tabular}


Table 8. - Measurements in mm for Laeviprosopon n. sp. FRANŢESCU, 2009.

\begin{tabular}{|c|c|c|c|c|c|c|c|c|c|c|c|c|c|}
\hline Specimen & L & W & MWD & FW & FOW & MGRD & MGRW & CGD & OOSD & CRL & CRD & OA & LA \\
\hline LPBIIlart-161-1 & 7.51 & 5.04 & 4.19 & & 3.20 & 4.19 & 2.23 & 3.09 & & 1.06 & 7.11 & & 25 \\
\hline LPBIIlart-161-2 & & & & & & & 2.66 & & & & & & \\
\hline
\end{tabular}


Table 9. - Measurements in mm for Verrucarcinus n. sp. FRANŢESCU, 2009.

\begin{tabular}{|c|c|c|c|c|c|c|c|c|c|c|c|c|c|}
\hline Specimen & L & W & MWD & FW & FOW & MGRD & MGRW & CGD & OOSD & CRL & CRD & OA & LA \\
\hline LPBIllart-160 & 12.08 & 9.54 & 8.18 & & 6.44 & 5.19 & 3.78 & 3.18 & & 2.88 & 9.13 & 67 & 19 \\
\hline
\end{tabular}


Table 10. - Measurements in mm for Lecythocaris n. sp. FRANȚESCU, 2009.

\begin{tabular}{|c|c|c|c|c|c|c|c|c|c|c|c|c|c|}
\hline Specimen & L & W & MWD & FW & FOW & MGRD & MGRW & CGD & OOSD & CRL & CRD & OA & LA \\
\hline LPBIllart-162 & 6.63 & 6.98 & 3.92 & & 3.76 & 3.92 & 1.60 & & & 1.17 & 5.88 & & 35 \\
\hline
\end{tabular}


Table 11. - Measurements in mm for Longodromites angustus REUSS 1858.

\begin{tabular}{|c|c|c|c|c|c|c|c|c|c|c|c|c|c|}
\hline Specimen & L & W & MWD & FW & FOW & MGRD & MGRW & CGD & OOSD & CRL & CRD & OA & LA \\
\hline LPBIIlart-163-1 & 6.48 & 4.71 & 3.11 & & 4.26 & 3.11 & 1.74 & 2.75 & & 1.49 & 5.49 & & 16 \\
\hline LPBIIlart-163-2 & 12.26 & 9.35 & 5.46 & & 8.36 & 5.96 & 3.68 & 4.96 & & 2.23 & 10.19 & 55 & 19 \\
\hline LPBIIllart-163-3 & 6.02 & 4.34 & 2.98 & 1.60 & 3.64 & 3.27 & 1.60 & 2.67 & & 1.27 & 5.30 & 47 & 24 \\
\hline LPBIIllart-163-4 & & 4.63 & & & & & & & & 1.05 & & & \\
\hline LPBIIlart-163-5 & & & & & & & & & & & & & \\
\hline
\end{tabular}


List of all the specimens described in this paper, and the GPS coordinates of the collecting sites.

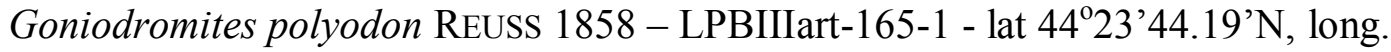
$28^{\circ} 33^{\prime} 42.43^{\prime \prime} \mathrm{E}$

Goniodromites polyodon REUSS 1858 - LPBIIIart-165-2 - lat 44²3'44.19'N, long. $28^{\circ} 33^{\prime} 42.43^{\prime \prime} \mathrm{E}$

Goniodromites polyodon REUSS 1858 - LPBIIIart-165-3 - lat 44²3'44.19'N, long. $28^{\circ} 33^{\prime} 42.43^{\prime \prime} \mathrm{E}$

Goniodromites polyodon REUSS 1858 - LPBIIIart-165-4 - Waypoint 130: lat. $44^{\circ} 23^{\prime} 44.8^{\prime \prime} \mathrm{N}$, long. $28^{\circ} 33^{\prime} 33.6^{\prime \prime}$ (stone piles)

Goniodromites polyodon REUSS 1858 - LPBIIIart-165-5 - Waypoint 131: lat. $44^{\circ} 23^{\prime} 49.9^{\prime \prime} \mathrm{N}$, long. $28^{\circ} 33^{\prime} 42.6^{\prime \prime}$ (quarry itself)

Goniodromites polyodon REUSS 1858 - LPBIIIart-165-6 - Waypoint 131: lat. $44^{\circ} 23^{\prime} 49.9^{\prime \prime} \mathrm{N}$, long. $28^{\circ} 33^{\prime} 42.6^{\prime \prime}$ (quarry itself)

Goniodromites polyodon REUSS 1858 - LPBIIIart-165-7 - Waypoint 131: lat. $44^{\circ} 23^{\prime} 49.9^{\prime \prime} \mathrm{N}$, long. $28^{\circ} 33^{\prime} 42.6^{\prime \prime}$ (quarry itself)

Goniodromites polyodon REUSS 1858 - LPBIIIart-165-8 - Waypoint 131: lat. $44^{\circ} 23^{\prime} 49.9^{\prime \prime} \mathrm{N}$, long. $28^{\circ} 33^{\prime} 42.6^{\prime \prime}$ (quarry itself)

Goniodromites polyodon REUSS 1858 - LPBIIIart-165-9 - Waypoint 131: lat. $44^{\circ} 23^{\prime} 49.9^{\prime \prime} \mathrm{N}$, long. $28^{\circ} 33^{\prime} 42.6^{\prime \prime}$ (quarry itself) 
Goniodromites polyodon REUSS 1858 - LPBIIIart-165-10 - lat. 44³2’38.8’N, long. $28^{\circ} 2^{\prime} 39.11^{\prime \prime}$

Goniodromites polyodon REUSS 1858 - LPBIIIart-165-11 - lat. 44³2’38.8’N, long. $28^{\circ} 2^{\prime} 39.11^{\prime \prime}$

Goniodromites polyodon REUSS 1858 - LPBIIIart-165-12 - Waypoint 132: lat.

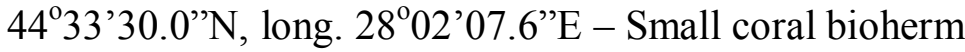

Goniodromites polyodon REUSS 1858 - LPBIIIart-165-13 - Waypoint 132: lat.

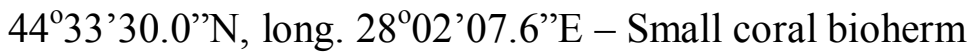

Goniodromites polyodon REUSS 1858 - LPBIIIart-165-14 - Waypoint 132: lat.

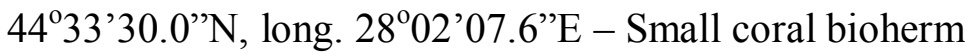

Goniodromites polyodon REUSS 1858 - LPBIIIart-165-15 - Waypoint 132: lat. $44^{\circ} 33^{\prime} 30.0^{\prime \prime} \mathrm{N}$, long. $28^{\circ} 02^{\prime} 07.6^{\prime \prime} \mathrm{E}-$ Small coral bioherm

Goniodromites polyodon REUSS 1858 - LPBIIIart-165-16 - Waypoint 132: lat. $44^{\circ} 33^{\prime} 30.0^{\prime}{ }^{\prime} \mathrm{N}$, long. $2^{\circ} 02^{\prime} 07.6^{\prime \prime} \mathrm{E}-$ Small coral bioherm

Goniodromites polyodon REUSS 1858 - LPBIIIart-165-17 - Waypoint 133: lat. $44^{\circ} 34^{\prime} 02.3^{\prime \prime} \mathrm{N}$, long. $28^{\circ} 02^{\prime} 00.3^{\prime \prime} \mathrm{E}$

Goniodromites polyodon REUSS 1858 - LPBIIIart-165-18 - Waypoint 133: lat. $44^{\circ} 34^{\prime} 02.3^{\prime \prime} \mathrm{N}$, long. $28^{\circ} 02^{\prime} 00.3$ '”

Goniodromites polyodon REUSS 1858 - LPBIIIart-165-19 - Waypoint 131: lat. $44^{\circ} 23^{\prime} 49.9^{\prime \prime} \mathrm{N}$, long. $28^{\circ} 33^{\prime} 42.6^{\prime \prime}$ (quarry itself)

Goniodromites polyodon REUSS 1858 - LPBIIIart-165-20 - lat 442ㅇ'44.19’N, long. $28^{\circ} 33^{\prime} 42.43^{\prime \prime} \mathrm{E}$ 
Goniodromites cf. bidentatus REUSS 1858 - LPBIIIart-166 - lat. 44³2’38.8”N, long.

Goniodromites n. sp. FRANȚESCU, 2009 - LPBIIIart-164-1 Holotype - Waypoint 131: lat. $44^{\circ} 23^{\prime} 49.9^{\prime \prime} \mathrm{N}$, long. $28^{\circ} 33^{\prime} 42.6^{\prime \prime}$ (quarry itself)

Goniodromites n. sp. FRANȚESCU, 2009 - LPBIIIart-164-2 Paratype - Waypoint 132: lat.

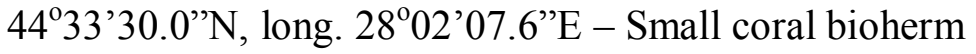

Goniodromites n. sp. FRANȚESCU, 2009 - LPBIIIart-164-3 Paratype - Waypoint 133: lat. $44^{\circ} 34^{\prime} 02.3^{\prime \prime} \mathrm{N}$, long. $28^{\circ} 02^{\prime} 00.3^{\prime \prime} \mathrm{E}$

Goniodromites sp. REUSS 1858 - LPBIIIart-168-1 - lat 44²3'44.19’N, long. $28^{\circ} 33^{\prime} 42.43^{\prime \prime} \mathrm{E}$

Goniodromites sp. REUSS 1858 - LPBIIIart-168-2 - lat 44²3'44.19’N, long. $28^{\circ} 33^{\prime} 42.43^{\prime \prime} \mathrm{E}$

Goniodromites sp. REUSS 1858 - LPBIIIart-168-3 - lat 44²3'44.19’N, long. $28^{\circ} 33^{\prime} 42.43^{\prime \prime} \mathrm{E}$

Goniodromites sp. REUSS 1858 - LPBIIIart-168-4 - lat 44²3'44.19’N, long. $28^{\circ} 33^{\prime} 42.43^{\prime \prime} \mathrm{E}$

Goniodromites sp. REUSS 1858 - LPBIIIart-168-5 - lat 44²3'44.19’N, long. $28^{\circ} 33^{\prime} 42.43^{\prime \prime} \mathrm{E}$

Goniodromites sp. REUSS 1858 - LPBIIIart-168-6 - Waypoint 131: lat. 44²3'49.9” N, long. 28 $33^{\prime} 42.6^{\prime \prime}$ (quarry itself)

Goniodromites sp. REUSS 1858 - LPBIIIart-168-7 - Waypoint 131: lat. 44 ${ }^{\circ} 23$ '49.9” N, long. 28³3'42.6” (quarry itself) 
Goniodromites sp. REUSS 1858 - LPBIIIart-168-8 - Waypoint 131: lat. 44²3'49.9” N, long. 28 $33^{\prime} 42.6^{\prime \prime}$ (quarry itself)

Goniodromites sp. REUSS 1858 - LPBIIIart-168-9 - Waypoint 131: lat. 44²3'49.9” N, long. 28³3'42.6”' (quarry itself)

Goniodromites sp. REUSS 1858 - LPBIIIart-168-10 - Waypoint 131: lat. 44²3'49.9” N, long. $28^{\circ} 33^{\prime} 42.6^{\prime \prime}$ (quarry itself)

Goniodromites sp. REUSS 1858 - LPBIIIart-168-11 - Waypoint 131: lat. 44²3'49.9” N, long. 28 33'42.6" (quarry itself)

Goniodromites sp. REUSS 1858 - LPBIIIart-168-12 - lat 44²3'44.19’N, long. $28^{\circ} 33^{\prime} 42.43^{\prime \prime} \mathrm{E}$

Goniodromites sp. REUSS 1858 - LPBIIIart-168-13 - lat. 44³2’38.8’N, long. $28^{\circ} 2^{\prime} 39.11^{\prime \prime}$

Goniodromites sp. REUSS 1858 - LPBIIIart-168-14 - lat. 44²32’38.8’N, long. $28^{\circ} 2^{\prime} 39.11^{\prime \prime}$

Goniodromites sp. REUSS 1858 - LPBIIIart-168-15 - lat. 44³2’38.8’N, long. $28^{\circ} 2 ’ 39.11^{\prime \prime}$

Goniodromites sp. REUSS 1858 - LPBIIIart-168-16 - lat. 44³2’38.8’N, long. $28^{\circ} 2{ }^{\prime} 39.11^{\prime \prime}$

Goniodromites sp. REUSS 1858 - LPBIIIart-168-17 - Waypoint 132: lat. 44³3’30.0’N, long. 2802'07.6’E - Small coral bioherm

Goniodromites sp. REUSS 1858 - LPBIIIart-168-18 - Waypoint 131: lat. 44²3'49.9” N, long. 28 33'42.6”' (quarry itself) 


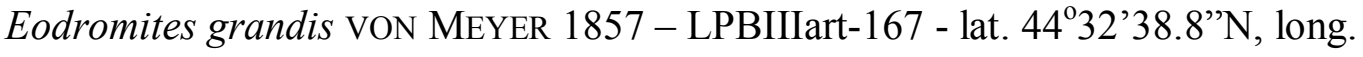
$28^{\circ} 2^{\prime} 39.11^{\prime \prime}$

Tanidromites cf. richardsoni WOODWARD, 1907 - LPBIIIart-159 - Waypoint 133: lat. $44^{\circ} 34^{\prime} 02.3^{\prime \prime} \mathrm{N}$, long. $28^{\circ} 02^{\prime} 00.3^{\prime \prime} \mathrm{E}$

Tanidromitidae n. g. n. sp. FRANȚESCU, 2009 - LPBIIIart-158 Holotype - lat. $44^{\circ} 32^{\prime} 38.8^{\prime \prime} \mathrm{N}$, long. $28^{\circ} 2^{\prime} 39.11^{\prime \prime}$

Laeviprosopon n. sp. FRANŢESCU, 2009 - LPBIIIart-161-1 Holotype - Waypoint 133: lat. $44^{\circ} 34^{\prime} 02.3^{\prime \prime} \mathrm{N}$, long. $28^{\circ} 02^{\prime} 00.3^{\prime \prime} \mathrm{E}$

Laeviprosopon n. sp. FRANȚESCU, 2009 - LPBIIIart-161-2 Paratype - Waypoint 133: lat. $44^{\circ} 34^{\prime} 02.3^{\prime \prime} \mathrm{N}$, long. $28^{\circ} 02^{\prime} 00.3^{\prime \prime} \mathrm{E}$

Verrucarcinus n. sp. FRANŢESCU, 2009 - LPBIIIart-160 Holotype - Waypoint 134: lat. $44^{\circ} 34^{\prime} 22.4^{\prime \prime} \mathrm{N}$, long. $28^{\circ} 02^{\prime} 04.9^{\prime \prime} \mathrm{E}$

Lecythocaris n. sp. FRANȚESCU, 2009 - LPBIIIart-162 Paratype - Waypoint 133: lat. $44^{\circ} 34^{\prime} 02.3^{\prime \prime} \mathrm{N}$, long. $28^{\circ} 02^{\prime} 00.3^{\prime \prime} \mathrm{E}$

Longodromites angustus REUSS 1858 - LPBIIIart-163-1 - Waypoint 133: lat. $44^{\circ} 34^{\prime} 02.3^{\prime \prime} \mathrm{N}$, long. $28^{\circ} 02^{\prime} 00.3^{\prime \prime} \mathrm{E}$;

Longodromites angustus REUSS 1858 - LPBIIIart-163-5 - Waypoint 133: lat. $44^{\circ} 34^{\prime} 02.3^{\prime \prime} \mathrm{N}$, long. $28^{\circ} 02^{\prime} 00.3^{\prime \prime} \mathrm{E}$

Longodromites angustus REUSS 1858 - LPBIIIart-163-2 - Waypoint 132: lat. $44^{\circ} 33^{\prime} 30.0^{\prime} \mathrm{N}$, long. $28^{\circ} 02^{\prime} 07.6^{\prime} \mathrm{E}$ - Small coral bioherm

Longodromites angustus REUSS 1858 - LPBIIIart-163-3 - Waypoint 132: lat. $44^{\circ} 33^{\prime} 30.0^{\prime \prime} \mathrm{N}$, long. 28 $02^{\circ} 07.6^{\prime} \mathrm{E}$ - Small coral bioherm 
Longodromites angustus REUSS 1858 - LPBIIIart-163-4 - Waypoint 132: lat.

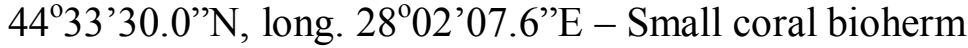

